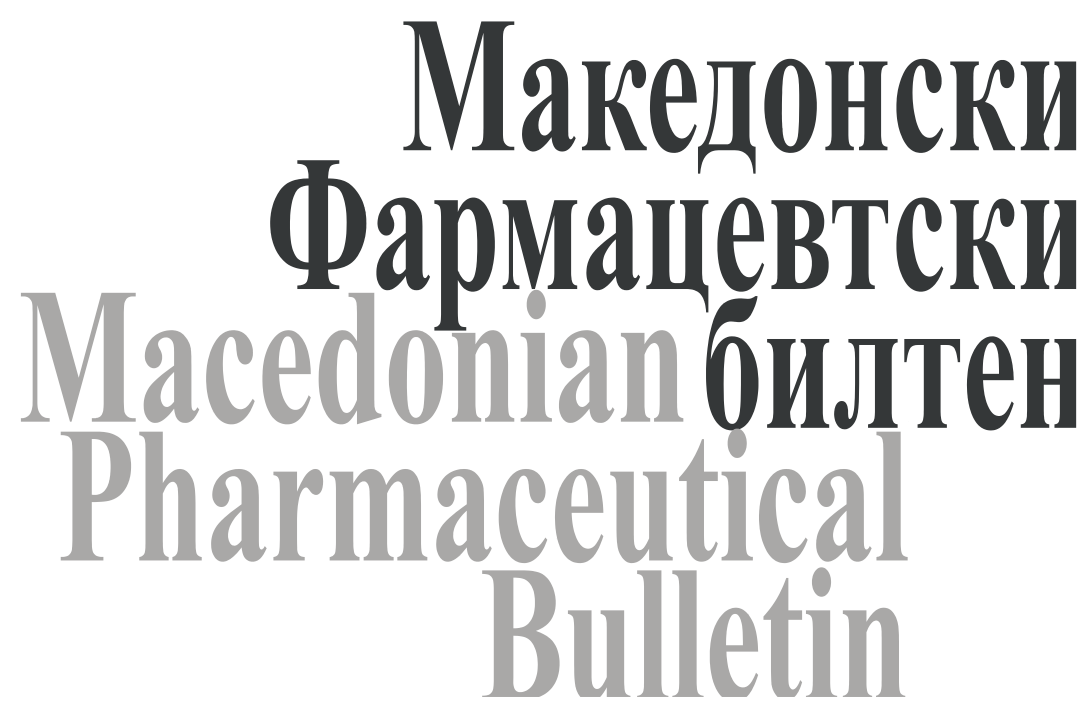

волумен 55 (1, 2) 2009 / volume 55 (1, 2) 2009

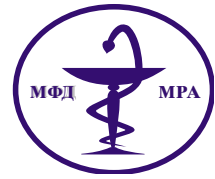

Македонско фармацевтско друштво, ул. Маршал Тито 13б/8, Скопје, Македонија Macedonian Pharmaceutical Society, Marshal Tito 13b/8, Skopje Macedonia 



\title{
A review of phytotherapy of Acne vulgaris
}

\author{
Marija Glavas Dodov ${ }^{1 *}$ and Svetlana Kulevanova ${ }^{2}$ \\ ${ }^{1}$ Institute of Pharmaceutical Technology, Faculty of Pharmacy, University Ss Cyril and Methodius, Skopje \\ ${ }^{21}$ Institute of Pharmacognosy, Faculty of Pharmacy, University Ss Cyril and Methodius, Skopje
}

Received: September 2009; Accepted: November 2009

\begin{abstract}
Acne vulgaris (acne) is a cutaneous pleomorphic disorder of the pilosebaceous unit involving abnormalities in sebum production and is characterized by both inflammatory (papules, pustules and nodules) and non-inflammatory (comedones, open and closed) lesions. Propionibacterium acnes and Staphylococcus epidermidis are common pus-forming microbes responsible for the development of various forms of acne. This disease remains a common condition in industrialized societies, with many mainstream treatment options available. There are many acne products on the market, and making an appropriate selection can be daunting.

Common therapies that are used for the treatment of acne include topical, systemic, hormonal, herbal and combination therapy. Topically used agents are benzoyl peroxide, antibiotics and retinoid. Systemically used agents are antibiotics and isotretinoin. However, all such treatments carry risks and none is completely satisfactory. Natural alternatives are gaining greater research support, and have much to offer clinically in this disorder.

This review focuses primarily on herbal treatments for acne that show scientific evidence of clinical efficacy, as well as the more common herbs shown to be useful in the treatment of this dermatologic disorder.
\end{abstract}

Key words: Acne vulgaris, acne treatment, herbal therapy, phytotherapy of acne

\section{Introduction}

Acne is a chronic disease of the pilosebaceous follicle that causes polymorph cutaneous lesions, among them comedones, papules, cysts, pustules, and abscesses which, after regression, may leave scars (Ramos-e-Silva and Carneiro, 2009). It is one of the most common skin diseases encountered by community physicians and dermatologists. Acne can present at any age, from neonates to mature adults, but is most prevalent and severe during adolescence, reaching a peak at the age of 14-17 years in females and 16-19 years in males (Lucky, 1998; Williams and Layton, 2006; Rivera, 2008)

The distribution of acne corresponds to the highest density of pilosebaceous units (face, neck, upper chest,

magl@ff.ukim.edu.mk shoulders, and back). Acne classification, scarring, acne rosacea, chloracne, acne associated with polycystic ovary syndrome, infantile acne and acne inversa have been reviewed elsewhere (Jacob et al., 2001; Shalita, 2004; Meixner et al., 2008).

Depending on the appearance different types of acne can be distinguished: $a$ ). blackheads, which are open comedones, where the top of accumulated sebum in the follicle opening oxidise and appears gray or black; $b$ ). whiteheads, which are closed comedones, where the follicle opening is clogged with trapped sebum and sealed by normal colored skin; c). cystic acne, tender, hard, purplish lumps often larger, and fluid-filled inflammatory swellings deep in the skin; d). acne scars, after healing of cystic acne small, depressed pits (acne scars) and pigmentation is left behind; e). acne rosacea, features redness (caused by dilatation of small blood vessels); f). acne pimples, mainly on the cheeks and forehead, common in women in middle life 
and $g$ ). acne vulgaris, different kind of pimples and blemishes (papules, pustules, nodules) which are pus-filled and inflamed firm spots below the skin (Shalita, 2004).

However, the term acne in medical circle is correlated to common acne (Acne vulgaris). In addition to adolescent acne, drugs are a relatively common cause of eruptions resembling acne. The most common are steroids, androgenic hormones, certain anti-convulsives, anti-tuberculosis drugs, lithium, and others. Exposure to iodides, bromides, and chlorines has also been reported to cause acne (Valeyrie-Allanore et al., 2007). Drug-induced acne or acneiform dermatoses that can have a sudden onset e.g. within one day of drug administration can be resolved after the drug is stopped. Acneiform dermatoses have an unusual lesion distribution, such as inflammatory papules and pustules that are small and uniform in size (monomorphic), and can lead to secondary comedones of which the earliest histological event is spongiosis followed by lymphocytic and neutrophilic infiltrates, respectively (Plewig and Jansen, 1998; Momin et al., 2009). Therefore, although the initial causes are different, the pathogenesis of Acne vulgaris can be similar.

The pathophysiology of acne is slowly unraveling, and although many factors remain undetermined, a better understanding of the mechanisms involved has led to an improvement in acne management over the last two decades. Four key factors have been identified in the etiology of acne: increased sebum production, follicular hyperkeratinization, colonization of the pilosebaceous unit with Propionibacterium acnes (P. acnes) and the production of inflammation (Kurokawa et al., 2009). Sebum hypersecretion in deformed follicles leads to formation of microcomedones, and the follicular hyperproliferation of microcomedones causes inflammation, and comedones in both open and closed types (black and white comedones) appearing in papules, pustules, nodules and cysts. The resulting skin condition with sebum enrichment is prone to the anaerobic growth of $P$. acnes, which is the main causative microorganism in acne. In addition, Staphylococcus epidermidis and Pitryosporum ovale are present in acne lesions. Proliferation of these microorganisms, mainly $P$. acnes, leads to inflammatory lesions and severe acne (Leyden, 2001; Zaenglein and Thiboutot, 2006; Morelli, 2007).

\section{Common acne treatments}

Acne needs to be managed aggressively from the outset using a combination of treatments directed against each of the relevant factors.

Generally, the choice of acne therapy is largely determined by the severity and extent of the disease. According to the type and severity, acne is often graded on a scale from mild-to-moderate inflammation, featuring predominantly comedones, erythematous papules to papulo-pustules, to moderate-to-severe papulo-nodular, nodulo-cystic and scarring inflammatory states (Olutunmbi et al., 2008).
However, defining optimum treatment strategies remains difficult as significant variability exists between individuals, both in terms of clinical presentation (disease duration, predisposition to scarring and post inflammatory hyperpigmentation) and response to previous treatments.

In approximately $60 \%$ of cases, acne is a self-limiting condition that can be managed with combination treatment followed by topical maintenance therapy (Thiboutot et al., 2009). In other cases, acne follows a chronic course that requires treatment for a prolonged period. Even mild acne can persist for 4-6 years, and in severe cases, the natural history could be in excess of 12 years (Gollnick et al., 2008). The reason as to why acne becomes chronic in some patients is not well understood, and predicting which patients will have persistent and/or refractory acne is very difficult. Factors that link to poor prognosis include early onset, hyperseborrhea, truncal acne and scarring (Dreno et al., 2006). A logical understanding of the pathophysiology of acne and the impact of therapies on these etiological factors should form the foundation of any treatment selection.

For mild and moderate acne, over-the-counter (OTC) and prescription medications may be the only treatment required. The most frequently used topic substances in acne treatment are retinoids, benzoyl peroxide, antibiotics, antiseborrheic medications, salicylic acid, alpha hydroxy acid, azelaic acid, nicotinamide, and keratolytic soaps (Gollnick and Krautheim, 2003; Ramos-e-Silva and Carneiro, 2009). Oral medications are used in severe cases, when an inflammatory component is present and in topical resistant cases. The most frequently prescribed are antibiotics, isotretinoin, and hormones. In very severe inflammatory cases it may be necessary to use systemic corticoids. Systemic treatment can be used even in mild cases, if there is intolerance to the topical treatment or where topical therapy has failed. Basic topical and systemic protocols may include several therapies, used according to the severity of each case (Auffret, 2000; Usatine and Quan, 2000; Bershad, 2001; Oberemok and Shalita, 2002).

However, these drugs produce a number of potential side effects and development of resistance to frequently used antibiotics. This leads to treatment failure with previously used successful therapy. Therefore, an alternative for the treatment of acne have been studied and developed and as a result natural approaches to combating acne and its disfiguring effects have gained popularity. Numbers of conventional and novel herbal cosmetics are useful to treat damaged skin (Amit et al., 2007; Ashawat et al., 2007; Chanchal and Swarnlata, 2008).

Acne can be cured by herbs either consuming internally or externally or with both. Topical herbal treatment is preferable choice of consumers as ease of application and it surpasses the bitter taste of herbal formulation (when taken internally). Because herbs are safe, efficacious and the added advantage of multi functionality, herbs are increasingly being used in mainstream cosmetic 
products, including acne-fighting compositions (Aburjai and Natsheh, 2003; Chanchal and Swarnlata, 2008; Kumar et al., 2008). Although some of the herbs are scientifically explored for their efficacy in treatment of acne but still many herbs are remain untouched by scientist.

This review focuses on the benefits of some herbs for the treatment of Acne vulgaris. The purpose of this study is to open new avenues and set trends for the improvement of medicinal uses of herbs for acne treatment and also reflects the traditional knowledge which provides the base for clinical research to be carried out to explore the active compounds which are responsible for anti-acne activities.

\section{Herbal therapy of acne}

The quest for medications and cosmetic measures to combat acne continues to be a major research and development initiative in the pharmaceutical and cosmetic industries. Number of herbs with a history of use in traditional cultures has entered in the growing cosmetic market.

Herbal formulations which contain many herbal extracts and have negligible adverse effects compared with modern medicines are commonly indicated for moderate and severe forms of acne. The efficacy of these agents in acne treatment is not only based on antimicrobial activity but also on their possessed antioxidant and anti-inflammatory properties by which they inhibit neutrophile migration and generation of reactive oxygen species. Also, various herbs are used in acne due to their skin detoxification property. Herbal extracts or oils may be used as monotherapy or in combination therapy. Till now, there are certain herbal extracts such as Angelica dahurica, Melaleuca alternifolia, Azadirachta indica, Rhizoma coptidis and Psidium guajava, that are proved to be more effective that antibiotics and retinoids in acne therapy (Kumar et al., 2008). Below some herbs are discussed in details for their potential efficacy in acne treatment.

\section{Arctium lappa (Great burdock)}

Burdock root extract has strong antibacterial and estrogenic effect and therefore it is used for treatment of different skin conditions like eczema, psoriasis, and acne.

The root of the burdock plant has been used in its native haunts, which include much of Africa and Europe, to improve immunity and overall health for at least 3,000 years. Like the honeybee, it has followed civilization. The plant produces a burr that gets stuck on people's clothing, and in this manner it has been carried to every continent. In recent years, the burdock has come to be considered a weed, despised by lawn owners for its tenacious growth habits.

The plant is a biennial, meaning that in its second year it blooms and then dies. Burdock spends its first year of life working industriously to store all the necessary elements to bloom the following year. The root is considered to be the most important part of the plant. It is usually plucked from the ground in the autumn of the plant's first year just as leafs started to fall.

The root contains lignans including arctigenin, glyco-

\section{$\underline{\text { Sesquiterpenes }}$}<smiles>C=C1CCC[C@]2(Cl)C[C@H](O)[C@@H](C(C)(C)O)C[C@H]12</smiles><smiles>C=C1CCC[C@]2(C)CC[C@H](C(C)(C)O)C[C@@H]12</smiles><smiles>CC(C)=C1C[C@]2(C)[C@@H](C)CCC[C@H]2CC1=O</smiles>

fukinone
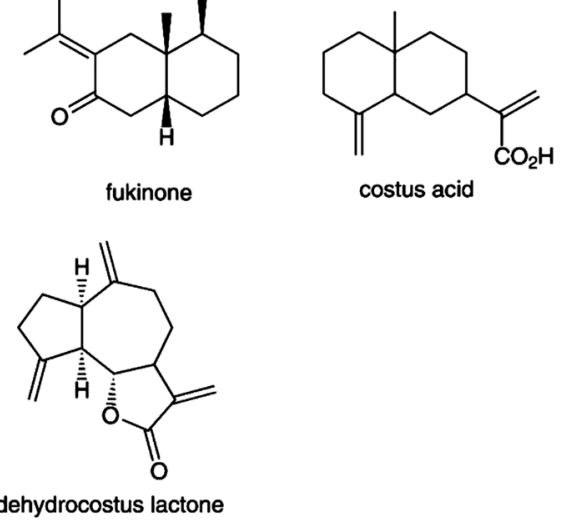

Thiophenes

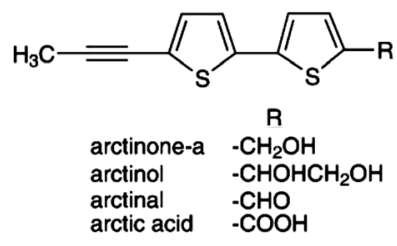

Polyenes<smiles>C=C(C)C#CC=CC</smiles>

trideca-1,11-diene-3,5,7,9-tetrayne

\section{Lignan}<smiles>[R6]Oc1ccc(CC2C(=O)OCC2Cc2ccc(OC)c(OC)c2)cc1OC</smiles>

R $\begin{array}{ll}\operatorname{arctin} & \text { glucosyl } \\ \text { arctigenin } & H\end{array}$
Polysaccharide

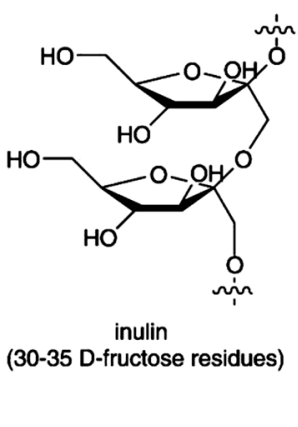

Fig. 1. Main constituents of Arctium lappa (Great burdock) (http://www.medicinescomplete.com/mc/ herbals/current/images/HrbburdockC001_default.png). 
side arctiin, and matairesinol, polyacetylenes including tridecadienetetraynes, tridecatrienetriynes, and a sulfur containing arctic acid (Fig. 1) (Park et al., 2007). It also contains amino acids including alpha guanidino-n-butyric acid, inulin, organic acids, fatty acids, and phenolic acids (Wang and Yang, 1993; (Community herbal monograph on A. lappa, radix, EMA/HMPC/246763/2009 Corr.1).

In general, burdock has the ability to gently stimulate health and, as a consequence, to improve the appearance of the skin. Elements contained in the plant improve the digestion and absorption of food, which makes the body stronger and better able to fight with infections. Furthermore, one of main attributes of burdock is its detoxification ability. The elimination of toxic substances via the urine is also aided by the burdock due to its mild diuretic property. Beyond its general health-stimulating abilities and like many other members of the daisy family, chamomile, elecampane, and calendula included, burdock is also considered to be one of the best tonic correctives of skin disorders. Burdock is a classic remedy for skin conditions which result with dry, scaly skin and cutaneous eruptions, eczema, psoriasis, dermatitis, boils, carbuncles, sties and chronic acne. Whereas calendula is only used externally to improve the skin's appearance, burdock has been recommended for internal (burdock tea, tincture, fluid extract, capsules) and external use (ointment, mask) in skin disorders.

Biological activities and pharmacological functions reported for burdock include anti-inflammatory, anticancer, antidiabetic, diuretic, antimicrobial, antiviral and free radical scavenging activities (EMA, HMPC, 2009). The Committee for herbal medicinal products from European Medicines Agency (EMA) besides use as an adjuvant in minor urinary tract complaints and for improvement of appetite, recommended root from this plant for treatment of seborrhoeic skin conditions (Community herbal monograph on A. lappa, radix, EMA/HMPC/246763/2009 Corr.1).

Its antibacterial (Pereira et al., 2005; Gentil et al., 2006), anti-inflammatory (Lin et al., 1996; Zhao et al., 2009) and antioxidant properties are particularly beneficial in acne treatment. Studies have shown that burdock root is able to inhibit the growth of the acne causing $P$. acnes bacteria which is found naturally in sebum. Also, burdock is rich with essential fatty acids, which contribute in regenerative processes in the skin. Burdock root is also able to regulate the function of the sebaceous glands, which are responsible for sebum production; the natural oil which builds inside clogged pores to create acne blemishes. On the other hand, in traditional Chinese medicine acne or eczema are seen as symptoms of system intoxication. Therefore, burdock and its clinically proven ability to act as a diuretic could effectively resolve problems affecting the skin.

\section{Oenothera biennis (Evening primrose)}

Evening primrose oil (EPO) made from the seeds of $O$. biennis is a fixed oil extremely rich in essential fatty ac- ids playing an important role in prostaglandin synthesis of human body. Prostaglandins help to regulate the action of several hormones like estrogens and have anti-inflammatory action. EPO has been used for a wide range of skin conditions such as eczema, psoriasis, and acne. It is also used as a dietary source of essential fatty acids and in the production of soaps and cosmetic ingredients. EPO has demonstrated significant effect in treatment of other diseases like asthma, rheumatoid arthritis, breast problems and metabolic disorders (Bayle and Usatine, 2009; Coffey, 1993; Hederos and Berg, 1996; Horrobin, 2000; Williams, 2003; Worm and Henz, 2000).

O. biennis is a member of evening primrose family (Onagraceae). It is found in fields, roadsides, prairies and waste places in the United States and south Canada, but it is widely naturalized elsewhere in temperate and subtropical regions. O. biennis is a biennial with large yellow flowers. In its first year, it forms a rosette of basal leaves. A tall flowering stem is formed in the second year. Plants produce one or two new flowers every evening.

Although the entire plant is edible, the flowers are added in salads, leaves eaten like greens, and the roots boiled like potatoes, it is primarily a minor oilseed crop used to produce the EPO. Seeds from $O$. biennis contain $14 \%$ of EPO which usually contains $50-70 \%$ cis-linoleic acid (LA) and 7-10\% cis-gamma-linolenic acid (GLA) (Fig. 2). Wild varieties of $O$. biennis contain highly variable amounts of LA and GLA. However, extensive crossbreeding has produced a commercial variety that consistently yields oil with $72 \%$ LA and 9\% GLA. Also found are $c i s-6,9,12$-octadecatrienoic acid, small amounts of oleic, palmitic, and stearic acids and steroids (campesterol, and beta-sitosterol). Mucilage and tannin in the plant parts have been also analyzed (http://www.drugs.com/npp/evening-primrose-oil.html).

GLA is essential for healthy skin functioning and is produced in human body from LA. Metabolites formed from GLA improve cellular membrane function and restore the skin lipid barrier, leaving it more hydrated, moisturized and protected from injury or stress. Because of its ability to dilute sebum production, EPO is effective at calming acne flare-ups, hydrating the skin at the same time. The use of EPO for acne treatment has become an all-natural alternative for those suffering from this skin condition. The use of EPO for acne treatment can be accomplished both externally (pure oil, creams, lotions) and internally (soft gelatin capsules) (http://www.cancer.org/docroot/ETO/content/ETO_5_3X_Evening_Primrose.asp?sitearea=ETO; http://www.herbs2000.com/herbs/herbs_evening_primrose.html).

There are also evidences that EPO may benefit patients with eczema (Bayle and Usatine, 2009; Coffey, 1993; Hederos and Berg, 1996; Horrobin, 2000; Williams, 2003; Worm and Henz, 2000). An improvement in clinical condition of children's atopic eczema was observed after four weeks of oral treatment with EPO (Biagi et al., 


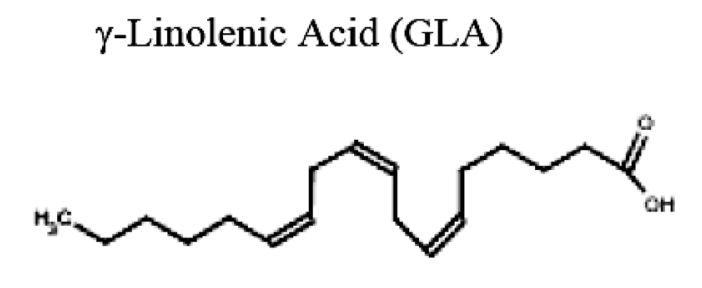

$\gamma$-Linolenic Acid (GLA)

Fig. 2. Major constituents of evening primrose oil.

1988). Other workers have reported that EPO oral supplementation could significantly improve skin problems in patients undergoing hemodialysis mainly due to the assumption that abnormalities in plasma composition of essential fatty acids may be associated with the etiology of uremic skin symptoms, like dryness, pruritus and erythema. After six weeks of therapy with EPO, significant increase in plasma dihomo-gamma-linolenic acid, a precursor of antiinflammatory prostaglandin E1 was observed, suggesting that oral supplementation with EPO could restore deranged plasma essential fatty acids and ameliorate skin symptoms (Yoshimoto-Furuie et al., 1999). Other workers have reported that the EPO therapeutic effect in atopic dermatitis patients with dry scaly skin lesions was associated with the normalization of serum gamma-interferon levels (Yoon et al., 2002).

Topical treatment with EPO was also beneficial in treatment of atopic dermatitis. A meta-analysis of randomized, placebo-controlled clinical trials of Efamol ${ }^{\circledR}$ (pure evening primrose oil) in atopic eczema have shown that the oil has a simultaneous, beneficial effect on itch/pruritis, crusting, edema and redness (erythema) that becomes apparent between 4 and 8 weeks after treatment was initiated (Morse and Clough, 2006). It is also important to notice that the use of EPO for management of atopic dermatitis is considered as safe and effective (Sanapati et al., 2008).

EPO has been also studied for its ability to calm and reduce inflammation due to the fact that in the human body GLA is converted to powerful prostaglandins that have potent anti-inflammatory and anti-irritant activities, protecting the skin from the damaging effects of UV radiation that lead to inflammatory skin conditions as well as skin aging. Studies on immunomodulatory and antiinflamatory activities showed that EPO proved useful effects in old age when delta-6-desaturation (delta-6-desaturate acts in the metabolism of linoleic and alpha-linolenic acid) activity decreases (Biagi et al., 1988; Charnock, 2000). Animal studies have shown that EPO stimulates COX-1 expression in some tissues (Fang et al., 1997), reduced platelet hyperaggregabilty in rabbits fed an atherogenic diet (De La Cruz et al., 1997) and GLA modulate the level of serum interferon-gamma, monocyte chemotactic protein-1 and tumor necrosis factor-alfa which may be a worthwhile line of treatment in

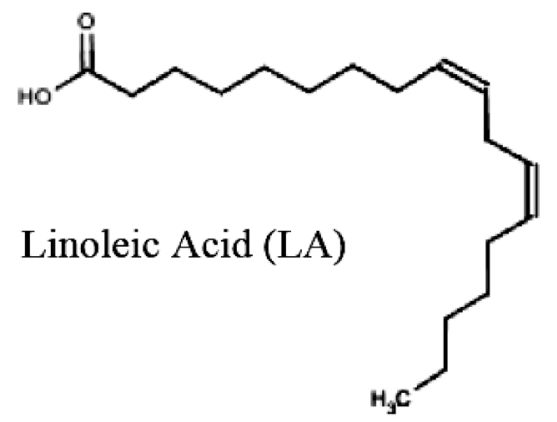

certain human diseases (Dirks et. al., 1998; Ismail et al., 2008). Also, experiments were performed to see the effect of $O$. biennis oil on antioxidant potential, given with hyperlipemic diet to New Zealand rabbits. It was observed that glutathione peroxidase activity reduced and the activities of glutathione reductase and transferase increased (De La Cruz et al., 1999). Also, EPO has shown antimicrobial activity against Staphylococcus aureus (Borchardt et al., 2009).

\section{Viola tricolor (Heartsease)}

Heartsease is a small plant of creeping and ramping habit, reaching at most $15 \mathrm{~cm}$ in height, with flowers about $1.5 \mathrm{~cm}$ in diameter. It grows in short grassland on farms and wasteland, chiefly on acid or neutral soils. It is usually found in partial shade. It flowers from April to September. The flowers can be purple, blue, yellow or white. They are hermaphrodite and self-fertile, pollinated by bees.

Viola tricolor herba cum flore contain different classes of secondary metabolites such as:

- Flavonoids. The quantity of flavonoids in the herb Viola tricolor and Viola arvensis was found to be $2.1 \%$ and $1.3 \%$, respectively. The main flavonoids of Viola tricolor are violanthin and rutin (quercetin 3-rutinoside) (Fig. 3), together with quercetin, luteolin and luteolin 7-glucoside. Other flavonoids: apigenin mono-C-glucosides: vitexin and isovitexin (saponaretin), luteolin mono-Cglucosides: orientin and isoorientin, and scoparin (3'-O-methylluteolin 8-Cglucoside), and few other O- or C-glycosides (Assessment report on Viola, EMA/HMPC/131735/2009).

- Sixteen flavonoid glycosides have been separated from the methanol extract of wild pansy by microliquid chromatography: four flavonol O-glycosides of kaempferol, quercetin, and isorhamnetin; nine flavone $\mathrm{C}$-glycosides of luteolin, chrysoeriol and apigenin, and three flavone $\mathrm{C}$, O-glycosides of apigenin (Toiu et al., 2007; Vukics et al. 2008a; Vukics et al. 2008b; Vukics, 2009). 
- Polysaccharides. The mucilage content in wild pansy herb is about $10 \%$. Hydrolysis of polysaccharides results in glucose $(35.1 \%)$, galactose $(33.3 \%)$, arabinose (18.1\%), rhamnose $(8.4 \%)$, uronic acid $(6.2 \%)$ and xylose $(5.1 \%)$ residues (Assessment report on Viola, EMA/HMPC/131735/2009). The water soluble fraction of polysaccharides is composed of glucose, galactose and arabinose residues $(2: 1.8: 1.1)$ and galacturonic acid, rhamnose and xylose. The pectin fraction contains galacturonic acid, glucose, and galactose (Assessment report on Viola, EMA/HMPC/131735/2009). According to Deters, the polysaccharides of wild pansy are mainly composed of galactose, glucose, galacturonic acid (34:29:27), whereas arabinose, rhamnose and mannose are minor components $(7: 2: 1)$ (Deters et al., 2005).

- Phenolic acids. The content is about $0.18 \%$, including trans-caffeic, $p$-coumaric, gentisic, protocatechuic, phydroxybenzoic, $p$-hydroxyphenylacetic, and vanillic acids, and $0.06 \%$ to about $0.3 \%$ salicylic acid and its derivatives, such as methyl salicylate and violutoside (violutin, glucosidoarabinoside of methyl salicylate), and monotropitoside (primveroside of methyl salicylate) (Assessment report on Viola, EMA/HMPC/131735/2009).

- Volatile oil. The content is reported with $0.0086 \%$, containing methyl salicylate as a principal constituent (Assessment report on Viola, EMA/ HMPC/131735/2009).

- Carotenoids. In wild pansy flowers occurs cis-violaxanthin (Szabolcs and Toth, 1970). Yellow blossoms yield carotenoids (9.69 mg/g dry weight), mainly 9-cis-violaxanthin $(51.3 \%)$, all-trans-violaxanthin (29.6\%), 13-cis-violaxanthin (1.7\%), 15-cis-violaxanthin $(0.6 \%)$, antherexanthin.

- Anthocyanins. Main pigment which is responsible for the violet colour of flowers of Viola tricolor is composed essentially of violanin (ca $33 \%$ ), a derivative of delphinidin with D-glucose,
L-rhamnose, p-coumaric acid, and 2.7 to $4 \%$ of potassium (Assessment report on Viola, EMA/ HMPC/131735/2009).

- Cyclotides (macrocyclic peptides) and other constituents (Assessment report on Viola, EMA/ HMPC/131735/2009).

The traditional use of heartsease goes back to ancient times. Heartsease preparations were used during the Middle Ages mainly as a remedy for various skin ailments and were mentioned according to Madaus (1938) by Lonicerus 1564; Hieronimus Bock 1565, Matthiolus (1501-1577) and Andreas Caesalpinus (died 1602). Its therapeutic activity is presented in Madaus "Lehrbuch der Biologischen

Heilmittel" (1938) and Jaretzky's "Pharmakognosie" (1937). The traditional use of heartsease in different diseases has been thoroughly documented in several handbooks and in folk tradition (Allen and Hatfield, 2004; Assessment report on Viola, EMA/HMPC/131735/2009). Laboratory experiments have confirmed that Viola extract exerts antimicrobial activity against gram positive and gram negative bacteria as have anti-inflammatory and other beneficial effects.

Antioxidant activity. Mantle et al. (2000) compared relative antioxidant activities of different British medicinal plants, Viola tricolor L. included. Antioxidative activity of the plants was tested through competitive scavenging of the ABTS (2,2`azinobis-(3-ethylbenzthiazoline-6-sulfonic acid)), presented in terms of $\mathrm{mM}$ Trolox equivalent $-\mathrm{mM}$ $\mathrm{TE}$ ) or $\mathrm{O}_{2}$ radicals (estimated as superoxide dismutase SOD activity) in vitro. Antioxidant activity (mM TE/g dry weight) of fresh tissue Viola tricolor leaf was $1.46 \pm 0.32$, whereas for flowers was $1.43 \pm 0.26$. This activity was quite potent, as comparable extracts of Ginkgo biloba gave values of 0.62 and $0.61 \mathrm{mM} \mathrm{TE} / \mathrm{g}$ dry weight, respectively (Vukics et al., 2008b). Therefore, authors concluded that heartsease, especially its flower, is a promising source of natural antioxidants. In addition, a significant correlation was found between the flavonoid content and antioxidant activity.<smiles>C[C@H]1O[C@H](c2c(O)c([C@H]3O[C@H](CO)[C@@H](O)[C@H](O)[C@H]3O)c(O)c3c(=O)cc(-c4ccc(O)cc4)oc23)[C@H](O)[C@@H](O)[C@H]1O</smiles>

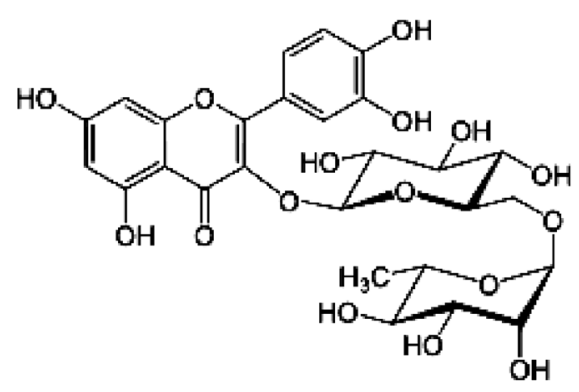

b)

Fig. 3. Main flavonoids in Viola tricolor herba cum flore a) Violanthin, b) Rutin. 
Antibacterial activity. The infusion, decoction and ethanol extract of Viola tricolor herb displayed significant inhibitory activity against Staphylococcus aureus, Bacillus cereus, Staphylococcus epidermidis and Candida albicans and moderate activity against Pseudomonas aeruginosa, Enterococcus faecalis, Escherichia coli and Klebsiella pneumoniae. The dichloromethane, ethyl acetate and methanolic fractions obtained by partitioning of Soxhlet of dried plant material, showed the lower activity. The higher activity of the extracts containing complexes of components of the plant, relative to that of the fractions comprising compounds of different polarity, suggested a synergism in antibacterial action between compounds of heartsease (Witkowska-Banaszczak et al., 2005).

Anti-inflammatory activity. The anti-inflammatory activity of the tincture from Viola tricolor aerial parts was tested in acute inflammation induced with oil of turpentine (i.m. $0.6 \mathrm{ml} / 100 \mathrm{~g}$ b.w.) in male Wistar rats. The results were compared with those from a positive control group with experimental inflammation and with those of a group treated with diclofenac $(30 \mathrm{mg} / 100 \mathrm{~g}$ b.w.). Viola tricolor extract (50 mg tincture/100 g b.w.) significantly reduced polymorphonuclear leukocytes and monocytes percentages and the activation of circulating phagocytes (Toiu et al., 2007).

Experimental preclinical data confirmed antioxidant, antibacterial and anti-inflammatory activity of heartsease in different skin conditions. Results from in vitro antimicrobial activity of Viola tricolor extracts support the traditional use of heartsease even though the effects are relatively weak compared to standard antibiotics.

None clinical studies were published on mono-preparations of heartsease. Randomized, double-blind, vehicle controlled study of an ointment composed of Mahonia aquifolium, Viola tricolor and Centella asiatica was performed on 88 patients between 18-65 years of age with mild to moderate atopic dermatitis. They were treated for 4 weeks with an ointment containing Mahonia aquifolium, Viola tricolor and Centella asiatica alcohol extracts (5g of each $/ 100 \mathrm{~g}$ of ointment). After 4 weeks of topical treatment the primary (erythema, oedema/papulation, oozing/ crust, excoriation and lichenification) and secondary (pruritus, global assessment of effectiveness and tolerability) endpoints were evaluated. No significant differences were observed between ointment containing Mahonia aquifolium, Viola tricolor and Centella asiatica alcohol extracts and the base. However, a sub-analysis indicated that the formulation might be useful under conditions of cold and dry weather (Klövekorn et al., 2007).

According to European community herbal monograph, indication for traditional use of herba cum flore of Viola tricolor, V. arvensis and V. vulgaris is for symptomatic treatment of mild seborrhoeic skin conditions (Community herbal monograph on Viola tricolor, herba cum flore, EMA/HMPC/131734/2009).

\section{Vitex agnus castus (Chaste tree)}

Vitex agnus castus (Verbernaceae) commonly known as chaste tree, chaste berry, or monk's pepper is a native of the Mediterranean region. It is a small deciduous tree that grows in Asia, Europe and North America. It bears slender spikes of violet blue, $8-10 \mathrm{~cm}$ flowers. Locally, the plant is used as insect repellent and insecticide. A wide range of medicinal applications are also shown by other plants of this family as berries are considered as tonic supplement for male and female reproductive system.

No single constituent has been identified as being the active one, in fact, with the exception of agnoside, all constituents are found in other plants. The total sum of constituents appears to generate a synergistic effect.

- Flavonoids: castican, orientin, isovitexin, vitexin.

- Iridoid glycosides: agnuside (the reference constituent for standardization), aucubin.

- Volatile oil (0.8-1.6\%): terpenoids (cineole, sabinene, limonene, camphene), $\alpha$ - and $\beta$-pinene.

- 3-Ketostaroids: Vitex has been found to contain 3 -ketosteroids (probably progesterone and 17- $\alpha$ hydroxyprogesterone) by thin-layer chromatography (Russo and Galletti, 1996).

The flowers and leaves may also possibly contain progesterone, 17-hydroxyprogesterone, testosterone, and epitestosterone although further research is needed. Other constituents in the flowering tops include flavonoids (particularly C-glycosides), and iridoids (aucubin, agnuside, eurostoside), 3-ketosteroids, essential oils (0.8-1.6\%): o-cymol, $\beta$-famescene, $a$ - and $\beta$-pinene, cineol, sabinene, limonene (Fig. 4) (Russo and Galletti, 1996).

Very often, acne flare-ups are related to the impending onset of menstruation. This particular type of acne highlights the fact that acne is often affected by hormone balance in the body. Much work has focused on the potential negative impact of androgenic hormones on acne; estrogen and progesterone can definitely also be involved. Vitex and Serenoa repens (saw palmetto) are most commonly used herbs for addressing hormonal issues that arise in acne. Studies have shown that the whole fruit extract of Vitex increases progesterone levels and decreases estrogen levels by acting upon follicle-stimulating hormone and luteinizing hormone levels in the pituitary gland, and decreases exceedingly high premenstrual prolactin levels via dopaminergic mechanisms (Bone, 1994). This may explain the benefit of Vitex in improving hormonal acne conditions.

In one placebo controlled trial of males and females, after 3 months of treatment with Vitex, both groups experienced a 70\% improvement in their acne. This was significantly better than the placebo. However, it should be noted that if Vitex is given to patient who does not have a relative progesterone deficiency, acne condition could be worse, and in fact may be initiated by Vitex use (Gardiner, 2000). 

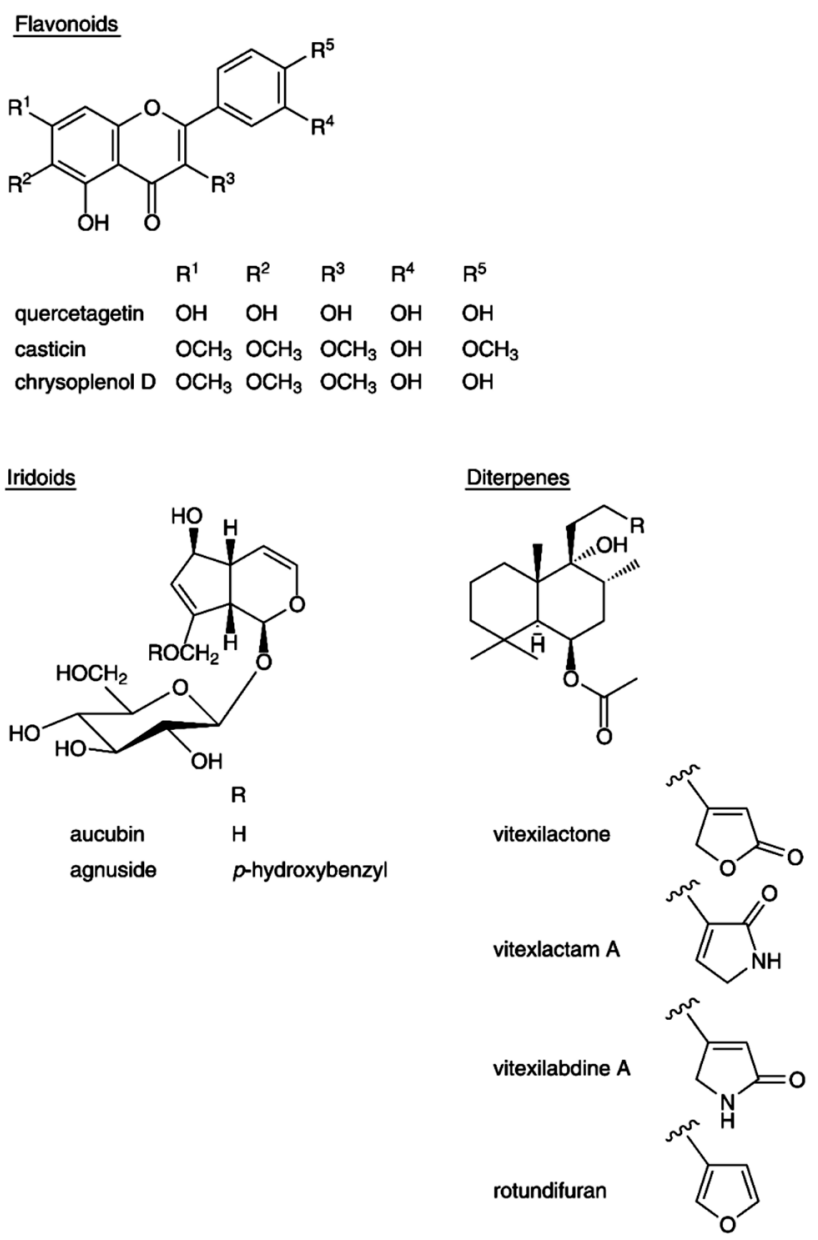

Fig. 4. Main constituents of $V$. agnus castus. (http:// www.medicinescomplete.com/mc/herbals/current/images/Hrbagnus_castusC001_default.png)

Preliminary German research also confirmed that chaste tree can be effective in moderate hormonal acne. For optimal anti-acne effects, chaste tree should be taken throughout the menstrual cycle. Vitex is often used together with vitamin B6, which has also proven to be quite helpful for resolving hormonal acne, although one comparative trial found that Vitex was superior to vitamin B6 for helping patients with symptoms of premenstrual syndrome (Yamell and Abascal, 2006).

As it was mentioned previously, conditions such as acne and seborrhoea (excessive secretion of sebum) result from the action of androgens on the skin. The severities of these effects are dependent upon androgen production by the ovary or adrenal gland and the bioavailability of androgen to peripheral tissues. This in turn is related to transport of plasma androgens by specific binding proteins and to peripheral metabolism of testosterone and androstenedione to the more potent dihydrotestosterone (DHT) (Reed and Frans, 1988). An effective anti-androgen is one which blocks the androgen receptor-mediated actions of testos- terone and DHT on skin. Although no actual clinical data are available, Serenoa repens (saw palmetto) extract is believed to be beneficial for topical use in anti-acne formulations. In vitro studies have shown that saw palmetto extract could inhibit both isoforms of the 5-alpha-reductase (enzyme that catalyze the conversion of testosterone to DHT), as well as binding of testosterone or DHT to androgen receptor (Bayne et al., 2000).

Other well-documented anti-androgenic herb is $G l y$ cyrrhiza glabra (licorice), although it also has not been studied for acne in clinical trials. Other hormone-balancing herbs may have a role in Acne vulgaris, including but not limited to, Medicago sativa (alfalfa), Chamaelirium luteum (false unicorn root), Verbena spp. (vervain), and Mitchella repens (partridge berry) (Yarnell and Abascal, 2006).

Among hormone-like effects in treatment of acne, the antibacterial activity of extracts of Vitex was tested against clinical isolates and drug resistant bacterial strains. The minimum inhibitory concentrations (MICs) of the extracts ranged between 0.312 and $5 \mathrm{mg} / \mathrm{ml}$. Among all the extracts, the ethyl acetate was found to be most active against all the tested bacterial species (Methicillin resistant Staphylococcus aureus $(0.312 \mathrm{mg} / \mathrm{ml})$, carbapenem resistant Acetobacter baumannii $(0.625 \mathrm{mg} / \mathrm{ml})$, ciprofloxacin resistant E.coli $(0.625 \mathrm{mg} / \mathrm{ml})$, Proteus vulgaris $(2.5 \mathrm{mg} /$ $\mathrm{ml})$, Salmonella typhi $(5 \mathrm{mg} / \mathrm{ml})$, Escherichia coli $(2.5 \mathrm{mg} /$ $\mathrm{ml})$, Enterococcus durans $(0.625 \mathrm{mg} / \mathrm{ml})$ and Pseudomonas aeruginosa $(2.5 \mathrm{mg} / \mathrm{ml}))$. Compare to standard streptomycin ethyl acetate extract showed good activity against all the three tested drug resistant bacteria. The present study indicates that the plant contains potential anti-bacterial components such as flavonoids, terpenoids and steroids that may be of use for development of phytomedicine for the therapy of tested bacterial diseases. The results of this study demonstrated that, ethyl acetate extract from the leaves of Vitex agnus-castus showed dominant antibacterial activity against potent clinical pathogens (Arokiyaraj et al., 2009). Research studies also confirmed the antifungal activity of seeds of Vitex negundo (Sathiamoorthy et al., 2007; Shaukat et al., 2009) and antioxidant and anti-inflammatory activities of methanol extract of the plant standardized on the content of flavonoids (Kulkarni et al., 2008), which effects could be also beneficial in treatment of various skin diseases.

\section{Hamamelis virginiana (Witch hazel)}

Hamamelis virginiana L. is a winter-flowering shrub, commonly known as witch hazel that is native from Nova Scotia, Canada to Texas and Florida in the U.S. It is best known for its decorative and fragrant yellow flowers and its bright yellow fall foliage.

Native Americans first learned how to use witch hazel for medicinal purposes when they used the extract to relieve bleeding, swelling, bruising and discomfort of external wounds. Hamamelis virginiana was also used in sweat 
lodges to soothe sore muscles. Native Americans also considered it as an astringent and purifier and a remedy for treating tumors. Throughout American history, uses for witch hazel have included treating insect bites and stings, rashes, hemorrhoids, sores, diarrhea and dysentery. Today, the external use of witch hazel is well known for the astringency associated with the tannin content of its leaves and bark.

The main characteristic constituent of Hamamelis virginiana is hamamelitannin (Fig. 5), a mixture of the $\alpha$ and $\beta$ - forms of $\left(2^{\prime}\right.$, 5-di-O-galloyl-hamamelose), its molecular structure bears two gallate moieties and a sugar unit, hamamelose (Tourino et al., 2008). Wang et al. (2003) developed an HPLC method for the determination of hamamelitannin, catechins, and gallic acid from witch hazel bark, twig and leaf. The concentrations in the bark for hamamelitannin, gallic acid, (+)-gallocatechin, and $(+)$-catechin were $4.77,0.59,0.22$, and $0.39 \%(w / w)$, respectively. Hamamelitannin and catechins were also detected in the leaves at concentrations of $<0.04 \%(w / w)$.

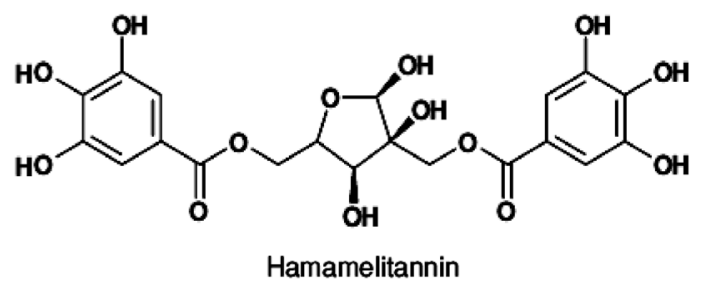

Fig. 5. Main tannin of Hamamelis virginiana bark.

According to Vennat et al. (1992), proanthocyanidins, phenolic acids and flavonoids have been identified in leaf extracts. Hydroxycinnamic acids and flavonoids (e. g. myricetin, leucodelphinidin, quercetin, kaempferol, and gallic acid) are found mainly in the leaves of Hamamelis virginiana. Phenolic compounds from leaves of Hamamelis virginiana were studied by Sagareishvili et al. (1999), where kaempferol, quercetin, trifolin, kaempferol 3-O- $\beta$ D-glucuronide, quercetin 3-O- $\beta$-D-glucuronide were isolated.

According to Engel et al. (1998), the composition of the volatile fraction obtained by water distillation from the leaves and bark of Hamamelis virginiana, and determined in detail by GC-MS, consists in about 175 (leaves) and 168 (bark) identified compounds or at least partly characterized on the basis of a computerized database (SeKoMS). The dominating substances were represented by a homologous series of alkanes, alkenes, aliphatic alcohols, related aldehydes, ketones, and fatty acid esters. Significant differences in the terpenoid and phenylpropanoid patterns of the products obtained from the bark and leaves are apparent: whereas the product of bark distillation was found to typically contain phenylpropanoids and mainly sesquiterpenoids, that obtained from the leaves included some distinct monoterpenoids detected in comparably higher amounts.
The chemical composition of the volatiles, when taken together with the absence of specific accumulation sites of lipophilics, emphasizes the definition "volatile fraction" rather than essential oil (Assessment report on Hamamelis virginiana, 2009).

Extracts from witch hazel bark have long been used in therapy of skin diseases and in cosmetic formulas (skin lotions, nourishing creams, pre- and after-shaves, etc.). When applied topically, witch hazel could significantly reduce bacteria grow, thus preventing inflammation and acne formation. Also, the tannin content in witch hazel has strong astringent as well as antioxidant properties. These astringent properties are cleansing to the skin, while minimizing the size of skin pores. Unlike many harsh commercial acne formulations, it is gentle, non-irritant and non-drying when used to tone and cleanse acne-infected or acne-prone skin. Furthermore, it helps to prevent any further infection from occurring. The tannins in witch hazel tighten pores and swollen veins, as well as reduce inflammation. The anti-inflammatory properties are further increased by the flavonoids and procyanadins, as well as resin, in the witch hazel plant.

Many acne treatments can irritate the skin, causing soreness, inflammation and dryness. Witch hazel, being a natural product, is well suited for skin care, because it does not disrupt the $\mathrm{pH}$ of the skin, which tends to cause irritation (Assessment report on Hamamelis virginiana, 2009).

Hamamelis extracts and isolated chemical constituents have shown anti-inflammatory activity in vitro and in vivo. It was found that polyphenols isolated from hamamelis stem and twig bark inhibited the synthesis of platelet activating factor in human polymorphonucleocytes (PMNs). Dimeric galloylated proanthocyanidins showed the strongest effects. The synthesis of leukotriene B4 in PMNs was inhibited by the tested substances. Oligomeric proanthocyanidins had stronger activity than hamamelitannin (Hartisch et al., 1997). According to Deters et al. (2001), polysaccharides and proanthocyanidins from hamamelis bark could influence on human skin keratinocyte proliferation and differentiation of cultured human keratinocytes, and influence on irritated skin. While the polysaccharide fraction, consisting mainly of arabinans and arabinogalactans, did not have effect human keratinocytes, the proanthocyanidins strongly increased the proliferation of the cells, while the differentiation was not influenced significantly. Within a preliminary cumulative in vivo study on SLS-irritated skin, proanthocyanidins were proven to reduce transepidermal water loss and erythema formation. Furthermore, a clinical scoring indicated that procyanidins can influence irritation processes significantly.

An aqueous ethanolic extract of hamamelis bark (ethanol $70 \%$ ) showed a significant anti-inflammatory effect $(43 \%$ inhibition of oedema; $\mathrm{p}<0.05)$ in the croton oil ear oedema test in mice when applied topically at $250 \mu \mathrm{g}$ per ear. This effect was shown to be mainly due to proanthocyanidins of molecular weight $\geq 3 \mathrm{kDa}$ (69\% inhibition at 
$250 \mu \mathrm{g}$ per ear; $\mathrm{p}<0.05$ ) obtained from this extract subjected to ultrafiltration and identified by TLC, HPLC. Proanthocyanidins also exhibit significant antiviral activity against Herpes simplex virus type 1 . In addition, the UV-concentrate displayed radical scavenging properties, inhibited $\alpha$-glucosidase as well as human leukocyte elastase (HLE). With the exception of the antioxidant potential and the inhibition of HLE-action the lower molecular fraction possessed weaker activities and contained mainly hamamelitannin, catechin, and unidentified constituents (Erdelmeier et al, 1996).

An aqueous extract of the leaves of Hamamelis inhibited the growth of Escherichia coli (MIC $0.4 \mathrm{mg} / \mathrm{ml}$ ), Staphylococcus aureus (MIC $0.4 \mathrm{mg} / \mathrm{ml}$ ), Bacillus subtilis (MIC $1.1 \mathrm{mg} / \mathrm{ml}$ ) and Enterococcus faecalis (MIC 3.0mg/ $\mathrm{ml}$ ). Aqueous extracts of the bark inhibited the growth of Escherichia coli, Staphylococcus aureus, Bacillus subtilis and Enterococcus faecalis (MIC for all $10.0 \mathrm{mg} / \mathrm{ml}$ ) (WHO monograph on Hamamelis, 2004).

\section{Eucaliptus globulus}

Two products from eucalyptus are in medicinal and commercial use, essential oil and dried extract, both obtained from leaves of Eucaliptus globulus Labill. (Myrtaceae). There are several hundred species of eucalytpus, most of them native to Australia. Like the Tea Tree, preparations of Eucalyptus have been an important part of traditional medicine of Australia's Aboriginal people for thousands of years. Eucalyptus essential oil is primarily produced from the leaves of the Blue Gum Eucalyptus (Eucalyptus globulus), although other species of eucalyptus are also used.

The primary component of eucalyptus essential oil is eucalyptol (1.8-cineol). Eucalytpol is a monoterpene molecule and it constitutes up to $90 \%$ of eucalyptus essential oil. In pure form, eucalyptol is a clear, colorless liquid that has a strong camphor-like smell. In addition to eucalyptus oil, eucalyptol is found in the essential oil of many other plants, although usually at lower concentrations. Eucalytpol is volatile and flammable and has a lower boiling point than water. It is also toxic to most animals when ingested in high quantities. Secondary components of eucalyptus essential oil are alpha-pinene, limonene, globulol and terpinen-4-ol (the primary component of tea tree oil). Several of these secondary components are known to have antibacterial and anti-inflammatory properties, but most of the activity of eucalyptus oil is attributed to its primary component, eucalyptol. On the other hand, the Eucalyptus globulus extract is one of the best-selling products today, manufactured from leaves of Blue Gum Eucalyptus and standardized on $25 \%$ of total chlorogenic acid (http://www. herb-extract.com/plant-extract/563839.html).

In traditional medicine, eucalyptus leaves have been used to prepare compresses, poultices, teas, etc. Eucalyptus essential oil and eucalyptol are both used extensively in modern medicine. Eucalyptol is toxic to many types of bacteria and is one of the active ingredients in antibacterial mouthwashes. Eucalyptol also has anti-inflammatory and cough suppressant properties, and is an ingredient in many cough drops. Inhalation of eucalyptol vapors is an effective short term analgesic and decongestant. Eucalyptus oil is a natural insect repellent for pests like mosquitoes (although it attracts certain types of bees).

There is little direct research into the effectiveness of eucalyptus essential oil in the treatment of acne. However, it is certainly possible that eucalyptus essential oil would be helpful in treating acne because of its antibacterial and anti-inflammatory properties (Athikomkulchai et al., 2008; Takahashi et al., 2004). The essential oil of E. globulus has a strong antimicrobial activity, especially against Streptococcus pyogenes, Escherichia coli, Candida albicans, Staphylococcus aureus, Acinetobacter baumannii, and Klebsiella pneumonia (Ghalem and Mohamed, 2008; Tabanca et al., 2001).

Essential oils of Eucaliptus species produced anti-inflammatory effects, demonstrated by inhibition of rat paw edema induced by carrageenan and dextran, neutrophil migration into rat peritoneal cavities induced by carrageenan, and vascular permeability induced by carrageenan and histamine (Silva et al., 2003).

Recent studies have shown that eucalyptus essential oil is effective against $P$. acnes, the primary bacteria in acne infections. It was reported that eucalyptus oil has similar antibacterial capabilities as benzoyl peroxide, a commonly used topical OTC medication for acne treatment (Athikomkulchai et al, 2008). Additionally, the antiinflammatory properties of eucalyptus oil may also be beneficial in acne condition. However, like most topical acne treatments, topical application of eucalyptus do not necessarily deliver enough active ingredients to the site of infection. Even though eucalyptus oil is effective against $P$. acnes in vitro, there is no real evidence that topically applied eucalyptus oil penetrates effectively into the follicle and sebaceous glands and its efficacy in the treatment of acne is unproven, at this time. It is also important to notice that topical applications of high concentration eucalyptus oil can produce side effects (Darben et al., 1998).

The second important product from eucalyptus is leaf dried extract. It contains gallic acid, ellagic acid, glucosides of quercetin and kaempferol, tannin dimer, oenothein $\mathrm{B}$, and a new gallotannin with structure 1,2,3,6-tetra-O-galloyi-beta-D-galactose (Amakura et al., 2009). The extract demonstrate strong antibacterial activity against Staphylococcus aureus, Streptococcus pneumonia and Haemophilus influezae as well as on other gram positive (C. pyogenese, $S$. aqueous, $S$ faecalis, B. stecrothermohplus, $S$. epidermis, B. cereus, B. polymyxa, B. anthracic, B. subtilis and $C$. sporogenes) and gram negative bacteria ( $K$. pneumonia, P. aeruginosa, E. coli and P. fluorescents) (Salari et al., 2006; Egwaikhide et al., 2008).

Eucalyptus bark extract represent also interesting nat- 
ural substance with specific chemical composition that include polygalloyl glucoses, catechin, epicatechin, ellagic acid, quercetin-3-O-rhamnoside and isorhamnteine glucosides and poses antioxidant activity (Vázquez et al., 2008).

\section{Melaleuca alternifolia (Tea-tree)}

Melaleuca alternifolia, Narrow-leaved Tea-tree, is a species of tree or tall shrub in the plant genus Melaleuca. Native to Australia, it occurs on the north coast and adjacent ranges of New South Wales. It grows along streams and on swampy flats, and is often the dominant species where it occurs. Characteristic of the myrtle family Myrtaceae, it is used to distil essential oil. It is the primary species for commercial production of Tea-tree oil (TTO, melaleuca oil), an essential oil with antibacterial (Carson et al., 2006) and antifungal activity (Hammer et al., 2003). More recently, the scientific community has confirmed that TTO has tremendous medicinal benefits and it is recognized as an excellent natural remedy for hundreds of bacterial and fungal skin ailments. Therefore it is used in a range of herbal medicine products and in cosmetic and toiletry products (deodorants, shampoos, soaps and lotions).

TTO is toxic if ingested in large amounts and if used topically in high concentrations may cause skin irritation (Hammer et al., 2006). No deaths have been reported.

TTO is a pale yellow color to nearly colorless and clear essential oil with a fresh camphoraceous odor. TTO should not be confused with tea oil, the sweet seasoning and cooking oil from pressed seeds of the tea plant Camellia sinensis (beverage tea), or the tea oil plant Camellia oleifera.

TTO is composed of terpene hydrocarbons, mainly monoterpenes, sesquiterpenes, and their associated alcohols. According TTO required chemical composition, as per ISO 4730 (2004), its chemical composition comprises terpinen-4-ol (30-48\%), $\gamma$-terpinene (10-28\%), $\alpha$-terpinene $(5-13 \%), 1.8$-cineole $(0-15 \%), \alpha$-terpinolene (1.5-5\%), $\alpha$-terpineol (1.5-8\%), $\alpha$-pinene (1-6\%) and pcymene $(0.5-8 \%)$ (Tea-tree oil, http://chemicalland21. com/lifescience/foco/TEA\%20TREE\%20OIL.htm).

Given the scope for batch-to-batch variation, it is fortunate that the composition of oil sold as TTO is regulated by an international standard for "Oil of Melaleuca - terpinen-4-ol type," which sets maxima and/or minima for 14 components of the oil. Notably, the standard does not stipulate the species of Melaleuca from which the TTO must be sourced. Instead, it sets out physical and chemical criteria for the desired chemotype. Six varieties, or chemotypes, of M. alternifolia have been described, each producing oil with a distinct chemical composition. These include a terpinen-4-ol chemotype, a terpinolene chemotype, and four 1.8-cineole chemotypes. The terpinen-4-ol chemotype typically contains levels of terpinen-4-ol of between 30 to $40 \%$ and is the chemotype used in commercial TTO production (Homer et al., 2000). Despite the inherent variabil- ity of commercial TTO, no obvious differences in its bioactivity either in vitro or in vivo have been noted so far. The components specified by the international standard were selected for a variety of reasons, including provenance verification and biological activity. For example, with provenance, the inclusion of the minor components sabinene, globulol, and viridiflorol is potentially helpful, since it may render the formulation of artificial oil from individual components difficult or economically untenable. With biological activity, the antimicrobial activity of TTO is attributed mainly to terpinen-4-ol, a major component of the oil. Consequently, to optimize antimicrobial activity, a lower limit of 30\% and no upper limit were set for terpinen-4ol content. Conversely, an upper limit of $15 \%$ and no lower limit were set for 1.8-cineole, although the rationale for this may not have been entirely sound. For many years cineole was erroneously considered to be a skin and mucous membrane irritant, fuelling efforts to minimize its level in TTO. This reputation was based on historical anecdotal evidence and uncorroborated statements (Williams and Home, 1988; Williams et al., 1990; Williams et al., 1993), and repetition of this suggestion appears to have consolidated the myth.

Recent data, do not indicate that 1.8-cineole is an irritant. Although minimization of 1.8-cineole content on the basis of reducing adverse reactions is not warranted, it remains an important consideration since 1.8-cineole levels are usually inversely proportional to the levels of terpinen-4-ol (Brophy et al., 1989), one of the main antimicrobial components of TTO (Carson and Riley, 1995; Raman et al., 1995; Carson et al., 2006).

Antimicrobial activity of TTO has received the most attention. The few earlier reports of the antibacterial activity of the TTO (Walsh and Longstaff, 1987; Low et al., 1974) have been reviewed (Carson et al., 1993; Christoph et al., 2000; Lis-Balchin et al., 2000; Messager et al., 2005) and in general previously obtained results were confirmed.

In the last two decades, many reports describing the antimicrobial activity of TTO appeared in the scientific literature. Although there was still a degree of discrepancy between the methods used in the different studies, the MICs reported were often relatively similar. A broad range of bacteria have now been tested for their susceptibilities to TTO. While most bacteria are susceptible to TTO at concentrations of $1.0 \%$ or less, MICs in excess of $2 \%$ have been reported for organisms such as commensal skin staphylococci and micrococci, Enterococcus faecalis, and Pseudomonas aeruginosa (Hammer et al., 1996). Few researchers published lower value of MIC $(0,25 \%)$ of TTO for Enterobacter aerogenes, Escherichia coli, Klebsiella pneumoniae, Proteus mirabilis, Salmonella choleraesuis, Shigella flexneri, Bacillus subtilis, Listeria monocytogenes, Staphylococcus aureus, S. saprophyticus, and S. xylosus (Harkenthal et al., 1999).

TTO is for the most part bactericidal in nature, although it may be bacteriostatic at lower concentrations. The activ- 
ity of TTO against antibiotic-resistant bacteria has attracted considerable interest, with methicillin-resistant Staphylococcus aureus (MRSA) receiving the most attention thus far. Several groups have evaluated the activity of TTO against MRSA, beginning with Carson et al. (1995), who examined 64 MRSA isolates from Australia and the United Kingdom, including 33 mupirocin-resistant isolates. The MICs and minimal bactericidal concentrations (MBCs) for the Australian isolates were $0.25 \%$ and $0.5 \%$, respectively, while those for the United Kingdom isolates were $0.312 \%$ and $0.625 \%$, respectively (Carson et al., 2006). Using a TLC-bioautographic technique Raman et al. (1995) investigated the antibacterial activity of TTO and isolated terpine-4-ol, alfa-terpineol and alfa-pinene, against Staphylococcus aureus, $S$. epidermidis and particularly against $P$. acnaes. The obtained results supported the use of TTO in acne treatment, demonstrating that terpinene-4-ol was not the sole active constituent of the oil. Among antibacterial, in vitro investigation of TTO against dermatophytes and filamentous fungi shown inhibitory and fungicidal activity (Hammer et al., 2002).

The mechanism of action of TTO against bacteria has now been partly elucidated. Prior to the availability of data, assumptions about its mechanism of action were made on the basis of its hydrocarbon structure and attendant lipophilicity. Since hydrocarbons partition preferentially into biological membranes and disrupt their vital functions, TTO and its components were also presumed to behave in this manner. This premise is further supported by data showing that TTO permeabilizes model liposomal systems. In previous work with hydrocarbons not found in TTO and with terpenes found at low concentrations in TTO, lysis and the loss of membrane integrity and function manifested by the leakage of ions and the inhibition of respiration were demonstrated. Treatment with TTO sensitized $S$. aureus cells to sodium chloride and produced morphological changes apparent under electron microscopy. Furthermore, no cytoplasmic membrane damage could be detected using the lactate dehydrogenase release assay, and only modest uptake of propidium iodide was observed after treatment with TTO (Carson et al., 2006; Cox et al., 2000).

In parallel with the characterization of the in vitro antimicrobial activity of TTO, the clinical efficacy of the oil has also been the subject of investigation. One of the first rigorous clinical studies assessed the efficacy of 5\% TTO in the treatment of acne by comparing it to $5 \%$ benzoyl peroxide (Bassett et al., 1990). The study found that both treatments reduced the numbers of inflamed lesions, although benzoyl peroxide performed significantly better than TTO. The benzoyl peroxide group showed significantly less oiliness than the TTO group, whereas the TTO group showed significantly less scaling, pruritis, and dryness. Significantly fewer overall side effects were reported by the TTO group ( 27 of 61 patients) than by the benzoyl peroxide group (50 of 63 patients). Few years ago, Enshaieh et al. (2007) confirmed the efficacy of 5\% topical
TTO gel in treatment of moderate acne vulgaris in a randomized, double-blind placebo-controlled study. The efficacy of TTO in dental applications, for the eradication of MRSA carriage, in the possibility of using TTO in handwash formulations for use in hospital or health care settings and as a mouthwash in the treatment of oropharyngeal candidiasis, has been also evaluated in numerous clinical studies (Carson et al., 2006).

Numerous recent studies support the anti-inflammatory activity of TTO. Research studies performed over the last decade have demonstrated that TTO affects a range of immune responses, both in vitro and in vivo. For example, the water-soluble components of TTO can inhibit the lipopolysaccharide-induced production of the inflammatory mediators tumor necrosis factor alpha (TNF- $\alpha$ ), interleukin$1 \beta$ (IL-1 $\beta$ ), and IL-10 by human peripheral blood monocytes by approximately $50 \%$ and that of prostaglandin $\mathrm{E}_{2}$ by about 30\% after $40 \mathrm{~h}$ (Hart et al., 2000). Further examination of the water-soluble fraction of TTO identified terpinen-4-ol, $\alpha$-terpineol, and 1.8-cineole as the main components, but of these, only terpinen-4-ol was able to diminish the production of TNF- $\alpha$, IL-1 $\beta$, IL- 8 , IL-10, and prostaglandin $\mathrm{E}_{2}$ by lipopolysaccharide-activated monocytes. The water-soluble fraction of TTO, terpinen-4-ol, and $\alpha$-terpineol also suppressed superoxide production by agonist-stimulated monocytes but not neutrophils (Brand et al., 2001). In contrast, similar work found that TTO decreases the production of reactive oxygen species by both stimulated neutrophils and monocytes and that it also stimulates the production of reactive oxygen species by nonprimed neutrophils and monocytes (Caldefie-Chézet et al., 2004). Human studies on histamine-induced wheal and flare provided further evidence to support the in vitro and animal data, with the topical application of neat TTO significantly reducing mean wheal volume but not mean flare area (Koh et al., 2002). Work has now shown that terpinen-4-ol, but not 1.8-cineole or $\alpha$-terpineol, modulates the vasodilation and plasma extravasation associated with histamine-induced inflammation in humans (Khalil et al., 2004).

\section{Ocimum sanctum (Holi basil)}

In traditional systems of medicine, different parts (leaves, stem, flower, root, seeds and even whole plant) of Ocimum sanctum Linn. (known as Tulsi in Hindi), a small herb seen throughout India, have been recommended for the treatment of bronchitis, bronchial asthma, malaria, diarrhea, dysentery, skin diseases, arthritis, painful eye diseases, chronic fever, insect bite etc. The Ocimum sanctum has also been suggested to possess antifertility, anticancer, antidiabetic, antifungal, antimicrobial, hepatoprotective, cardioprotective, antiemetic, antispasmodic, analgesic, adaptogenic and diaphoretic actions (Mondal et al., 2009; Singh et al., 2007).

Eugenol (1-hydroxy-2-methoxy-4-allylbenzene), the active constituent present in Ocimum sanctum, has been 
found to be largely responsible for the therapeutic potentials of the plant. Although because of its great therapeutic potentials and wide occurrence in India the practitioners of traditional systems of medicine have been using Ocimum sanctum for curing various ailments. A rational approach to this traditional medical practice with modern system of medicine is, however, not much available (Prakash and Gupta, 2005).

Chemical composition of $O$. sanctum means presence of volatile oil (0.4-0.8\%) containing chiefly eugenol app. $21 \%$ and $\beta$-caryophyllene $37 \%$ (eugenol content reaches maximum in spring and minimum in autumm). A number of sesquiterpenes and monoterpenes such as bornyl acetate, ß-elemene, methyleugenol, neral, ß-pinene, camphene, $\alpha$-pinene etc. are also present as constituents of the oil. Besides, triterpene component ursolic acid, sterols (campesterol, cholesterol, stigmasterol, ß-sitosterol) and methyl esters of common fatty acids are also key constituents of the plant oil (Ocimum sanctum, http://101herbs.com/ocimum sanctum.html).

From fresh leaves and stems of $O$. sanctum and further purification of the obtained extract, the few phenolic compounds were isolated: cirsilineol, cirsimaritin, isothymusin, isothymonin, apigenin, and rosmarinic acid, and appreciable quantities of eugenol (Kelm et al., 2000).

Gupta et al. (2007) isolated three new compounds, ocimumosides A and B and ocimarin (Fig. 6), were isolated from an extract of the leaves of holy basil, together with eight known substances, apigenin, apigenin-7-O$\beta$-D-glucopyranoside, apigenin-7-O- $\beta$-D-glucuronic acid, apigenin-7-O- $\beta$-D-glucuronic acid 6"-methyl ester, luteolin7-O- $\beta$-D-glucuronic acid 6"-methyl ester, luteolin-7-O- $\beta$ D-glucopyranoside, luteolin-5- $O-\beta$-D-glucopyranoside, and 4-allyl-1-O- $\beta$-D-glucopyronosyl-2-hydroxybenzene, and two cerebrosides.

In order to establish the therapeutic uses of $O$. sanctum in modern medicine, in last few decades several Indian scientists and researchers have studied the pharmacological effects of steam distilled, petroleum ether and benzene extracts of various parts of the plant and eugenol on immune system, reproductive system, central nervous system, cardiovascular system, gastric system, urinary system and blood biochemistry and have described the therapeutic significance of $O$. sanctum in management of various ailments. These pharmacological studies have established a scientific basis for therapeutic uses of this plant (Prakash and Gupta, 2005).

The most studies on biological effects are based on antimicrobial activity of $O$. sanctum essential oil (Dey and Choudhari, 1984; Mondal et al., 2007). The essential oil of $O$. sanctum has been effective against gram-positive and gram-negative bacteria and the properties were comparable with the effectiveness of clove oil. It also exhibited significant antimicrobial activities against some of the clinical isolates and multi-drug resistant Neisseria gonorrhoeae (Mondal et al., 2009). A comparative investigation has shown that the oil of sweet basil (O. basilicum) was even more effective against the $P$. acnes, in comparison to the oil of holy basil (O. sanctum), but both oils could be recommended for use in micro-emulsion formulations for acne skin care (Viyoch et al., 2006).

The aqueous and methanolic suspension of $O$. sanctum has shown to inhibit acute as well as chronic inflammation in rats. The test was conducted by carrageenan induced paw edema, croton oil induced granuloma and exudates, at a dose of $500 \mathrm{mg} / \mathrm{kg}$, bw/day (Godhwani et al., 1987). The oils extracted from fresh leaves (essential oil) and seeds (fixed oil) of $O$. sanctum have shown anti-inflammatory effects on experimental animals hind paw edema induced by carrageenan, serotonin, histamine and prostaglandin-E-2. These experimental rats were administered with essential oil $(200 \mathrm{mg} / \mathrm{kg}$, bw), and fixed oil $(0.1 \mathrm{ml} /$ $\mathrm{kg}$, bw) before injection of phlogistic agents and was compared with standard drug flurbiprofen. It was noted that extracts could significantly reduce the edema when compared with the saline treated control. However, its effect was less than the standard drug (Singh and Agarwal, 1991).

The mechanism of action of the anti-inflammatory effects of $O$. sanctum could be the cyclo-oxygenase and lipooxygenase pathways (Singh et al., 1996; Singh and Majumdar, 1995; 1997). In order to compare the anti-inflammatory effects of fixed oils of various species of Ocimum v.s. O. sanctum, O. basilicum, O. americanum, which possess varying proportions of unsaturated fatty acids (par-

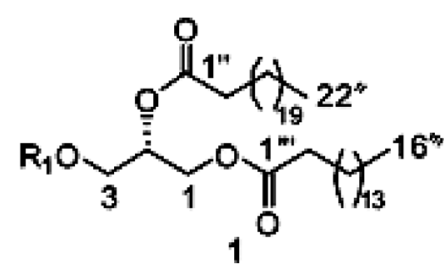

$1 \mathrm{R}_{1}=6$-deoxy-6-amino- $\alpha$-D-glucopyranosy $2 \mathrm{R}_{1}=\alpha$-D-galactopyranosyl $\left(1 \stackrel{n}{-} 6^{\prime}\right)-\mathrm{O}-(\mathrm{B}-\mathrm{D}$-galactopyranosyl<smiles>Cc1c(CCO)c(=O)oc2cc(O)ccc12</smiles>

3

Fig. 6. Structures of ocimumosides A (1) and B (2) and ocimarin (Gupta et al., 2007). 
ticularly linolenic acid) showed different response against phlogistic agent induced paw edema. Ocimum basilicum possess highest percentage of linolenic acid (21\%) and offered maximum inhibition of paw edema (72.42\%), $O$. Sanctum fixed oil containing $16.63 \%$ linolenic acid provided $68.97 \%$ inhibition while $O$. americanum offered least paw edema inhibition (Singh, 1998). Fixed oil of $O$. sanctum can inhibit enhanced vascular permeability and leukocyte migration as evidenced by carrageenan induced inflammatory stimulus (Singh et al., 1996). Extract of seeds from three plants including Ocimum sanctum have been studied for anti-inflammatory effects of carrageenan, leukotrine and arachiodonic acid induced paw edema in rats. Ocimum sanctum seed oil showed maximum percentage inhibition of leukotrine induced paw edema (Singh et al., 2008). According to Prakash and Gupta (2005), eugenol, active constituent of the $O$. sanctum essential oil, has been found as largely responsible for the therapeutic potentials of the plant. Anti-inflammatory activity of the eugenol iso- lated from the essential oil of $O$. sanctum was studied in Wistar rats by using carrageenan induced Hind paw edema method (Thakur and Pitre, 2009). The isolated eugenol and anti-inflammatory drug paracetamol (positive control) exhibited significant activity when compare with cararageenan control.

\section{Calendula officinalis (Marigold)}

Calendula officinalis, or (pot) marigold, is a common garden plant belonging to the Asteraceae family. Native to Southern Europe, Calendula grows up to $60 \mathrm{~cm}$ in height and produces large yellow or orange flowers. Like many other members of the Asteraceae family, which include daisies, arnica, chamomile, and yarrow, calendula is now cultivated throughout the world and is valued for its culinary and medicinal uses. The flowers are the part of the herb used medicinally (mainly because of its antibacterial, anti-inflammatory and antioxidant properties) either in

\section{Saponins}

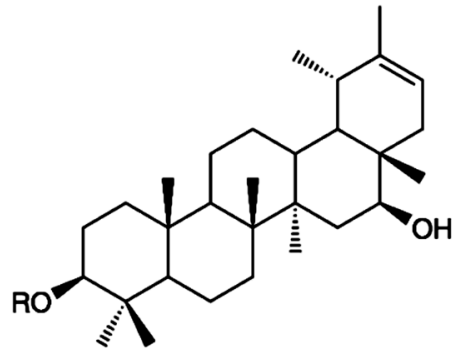

$\underline{\mathbf{R}}$ faradiol-3-O-laurate faradiol-3-O-myristate faradiol-3-O-palmitate laurate myristate palmitate

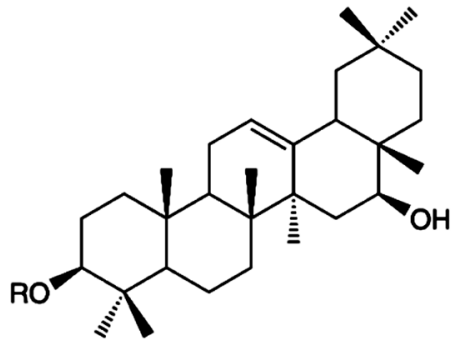

$\underline{B}$

maniladiol-3-0-laurate laurate maniladiol-3-O-myristate myristate

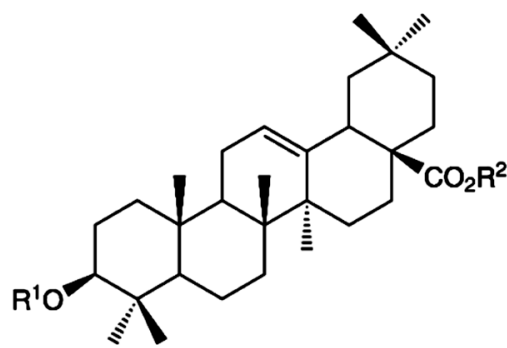

Calendulosides

\begin{tabular}{|c|c|}
\hline$\underline{\mathrm{R}}^{1}$ & $\underline{B}^{2}$ \\
\hline $\begin{array}{c}\text { glucose }(1 \rightarrow 4) \\
\text { galactose }(1 \rightarrow-3)\end{array}$ & glucose \\
\hline $\begin{array}{r}\text { glucose }(1 \rightarrow 4) \\
\text { galactose }(1 \rightarrow 3)\end{array}$ & $\mathrm{H}$ \\
\hline galactose $(1 \rightarrow 3)-$ glucuronic acid & glucose \\
\hline galactose $(1 \rightarrow 4)-$ glucuronic acid & H \\
\hline glucose $(1 \rightarrow 4) —$ glucuronic acid & H \\
\hline glucuronic acid & H \\
\hline
\end{tabular}

Fig. 7. Saponins of Calendula officinalis (http://www.medicinescomplete.com/mc/herbals/current/images/HrbcalendulaC001_default.png). 
the form of infusions, tinctures, liquid extracts, creams or ointments, or in one of a number of skin and hair products available as OTC or cosmetics.

A number of phytochemical studies have demonstrated the presence of several classes of chemical compounds in flowers or in other organs of marigold, the main ones being terpenoids, flavonoids, coumarines, quinones, volatile oil, carotenoids and amino acids (Muley et al., 2009). Various terpenoids and sterols have been reported from the petroleum ether extract of C.officinalis flowers such as: sitosterols, stigmasterols, diesters and monoesters of taraxasterol, lupeol, erythrodiol, ursadiol, faradiol, arnidiol, calenduladiol, oleanolic acid saponins (calenduloside $\mathrm{AH}$ ) and oleanane triterpene glycoside (calendulaglycosides) (Fig. 7). One new triterpenic ester of olanane series isolated from the flowers was cornulacic acid acetate (Naved et al., 2005).

Various flavonoids have been isolated from the ethanol extract of the inflorescence of $C$. officinalis. They include quercetin, isorhamnetin, isoquercetin, narcissin, calendoflaside, calendoflavoside, calendoflavobioside, rutin, isoquercitrin neohesperidoside, and different glycosides of isorhamnetin and quercetin (Muley et al., 2009; Vidal-Oliver et al., 1989). Different quinones, volatile oil, carotenoids, carbohydrates, lipids and other constituents were also identified in marigold flowers (Muley et al., 2009).

For centuries, marigold flowers have been used to treat a number of clinical conditions, specifically, different dermatological disorders. Whilst the many chemical constituents within marigold and the numerous actions of the plant suggest that marigold may be effective in treating a myriad of complaints. However, there is currently insufficient clinical evidence to support the use of pot marigold in conditions other than cutaneous lesions.

Marigold is considered a mainstay in alternative medicine for the treatment of inflammation, to speed wound healing and as an antiseptic. Available in topical herbal forms and as a homeopathic preparation, the anti-inflammatory (Braga et al., 2009; Chandran and Kuttan, 2008; Chandran et al., 2009; Della Loggia et al., 1994; Ukiya et al., 2006) and anti-bacterial (Lauk et al., 2003) properties of marigold may be helpful for treating dermatological conditions including acne (Muley et al., 2009).

Calendula officinalis flower extract have been proved for possessing significant anti-inflammatory activity against carrageenan and dextran-induced acute paw edema. In recent study conducted on flower extracts to find out mechanism involved in this, it was found that TNF-alpha production by macrophage culture treated with lipopolysaccharide was inhibited by $C$. officinalis extract. C. officinalis also contains flavonoids, which accounts for its anti-inflammatory impact (Preethi et al., 2009). Different hydroalcoholic extracts of marigold possesses proven antimicrobial, antifungal and antiviral properties against Staphylococcus aureus and Streptococcus fecalis Prophyromonas gingivalis, Fusobacterium nucleatum, Capnocytophaga gingivalis, Veilonella parvula, Eikenella corrodens, Peptostreptococcus micros and Actinomyces odontolyticus, Staphylococcus aureus, Sarcina lutea, Escherichia coli, Klebsiella pneumonia and Candida monosa on one hand, and on the other hand, the aetiology of acne.

Calendula off. is available in a number of ointment, cream and salve preparations in a variety of strengths. Calendula oils and infusions are also widely available in health-food stores and through online sources. Calendula off. is also commonly available in tea and liquid tinctures which can be applied directly to the acne prone areas of the skin.

\section{Conclusion}

Much disparate and introductory research exists on the effects of herbs on multiple aspects of acne. A comprehensive approach combining multiple herbs as well as lifestyle and dietary changes has helped people with acne in preliminary clinical trials. The continued resistance of mainstream dermatology to the possibility of this approach does not optimally serve patients who might be significantly helped by natural therapies. There are sufficient pilot data to warrant larger trials on various herbal medicines in isolation and combined with each other and other natural therapies. The data are also sufficient to support a recommendation for use of these herbs in clinical practice. Overall, herbal medicine has much to offer to improve our ability to deal with the complex issues acne presents.

However, an appropriate delivery system should be developed to impart their efficacies in addition to the standardization of these herbs. Furthermore, an optimized and effective dose should be evaluated prior to the development of preparations in order to avoid irritation or allergy in subjects with hypersensitive skin. Strict quality control will ensure their safety and efficacy. In addition, combination treatment should be conducted as it was found to be more effective than the application of a single product with regard to synergistic effects on the pathogenesis of acne.

\section{References}

Aburjat, T., Natsheh, F.M., 2003. Plants used in cosmetics. Phytother. Res. 17, 987-1000.

ACS (American Cancer Society). 2009. Evening primrose. Internet address: http://www.cancer.org/docroot/ETO/ content/ETO_5_3X_Evening_Primrose.asp?sitearea=ETO. Last updated on June 29, 2007. Last accessed on January 9, 2009.

Allen, D.E., Hatfield, G., 2004. Medicinal plants in folk tradition: An ethnobotany of Britain \& Ireland. TimberPressInc.,Portland, Cambridge.

Amakura, Y., Yoshimura, M., Sugimoto, N., Yamazaki, T., Yoshida, T., 2009. Marker constituents of the natural antioxidant Eucaliptus leaf extrasct for the evaluation of food additives. Biosci. Biotechol. Biochem. 73(5), 1060-1065.

Amit, G., Ashawat, M.S., Shailendra, S., Swarnlata, S., 2007. Phyrosome: a novel approach towards functional cosmetics. 
Journal of Plant Sciences 26, 644-649.

Arokiyaraj, S., Perinbam, K., Agastian, P., Kumar, R.M., 2009. Phytochemical analysis and antibacterial activity of Vitex agnus-castus. Int. J. Green Pharm. 3, 162-164.

Ashawat, M.S., Amit, G., Shailendra, S., Swarnlata, S., 2007. Role of highly specific and complex molecules in skin care, Int. J. Cancer Res. 3(4), 191-195.

Assessment report on Arctium lappa L., radix, EMA/ HMPC/246764/2009, Committee on Herbal Medicinal Products (HMPC), Accessed at: http://www.ema.europa. eu/docs/en GB/document library/Herbal - HMPC assessment_report/2011/04/WC500105233.pdf

Assessment report on Hamamelis virginiana L., cortex, Hamamelis virginiana L., folium, Hamamelis virginiana L., folium et cortex aut ramunculus destillatum, 2009. Committee on herbal medicinal products, EMA, London.

Athikomkulchai, S., Watthanachaiyingcharoen, R., Tunvichien, S., Vayumhasuwan, P., Karnsomkiet, P., Sae-Jong, P., Ruangrungsi, N., 2008. The development of anti-acne products from Eucalyptus Globulus and Psidium Guajava oil. J. Health Res. 22(3), 109-113.

Auffret, N., 2000. Acne today. What's new? Presse Medicale 29(19), 1091-1097.

Bassett, I. B., Pannowitz, D. L., Barnetson, R. S., 1990. A comparative study of tea-tree oil versus benzoylperoxide in the treatment of acne. Med. J. Aust. 153, 455-458.

Bayle, B., Usatine, R., 2009. Evening primrose oil. Am. Fam. Physician. 80(12), 1405-1408.

Bayne, C.W., Ross, M., Donnelly, F., Habib, F.K., 2000. The selectivity and specificity of the action of the lipido-sterolic extract Seronoa repens (Prmixon) on prostate. J. Urol. 164(3), 876-891.

Bershad, S.V., 2001. The modern age of acne therapy: A review of current treatment options. Mount Sinai Journal of Medicine 68(4-5), 279-286.

Biagi, P.L., Bordoni, A., Masi, M., Ricci, G., Fanelli, C., Patrizi, A., Ceccolini, E., 1988. A long-term study on the use of evening primrose oil (Efamol) in atopic children. Drugs Exp. Clin. Res. 14(4), 285-90.

Bone, K., 1994. Vitex agnus castus: Scientific studies and clinical applications. Eur. J. Herbal Med. 1, 12-15.

Borchardth, J.R., Wyse, D.L., Sheaffer, CC., Kauppi, K.L., Fulcher, R.G., Ehlke, N.J., Biesboer, D.D., Bey, R.F., 2009. Antioxidant and antimicrobial activity of seed from plants of Missdisippi river basin. J. Med. Plant Res. 3(10), 707-718.

Braga, P.C., Dal Sasso, M., Culici, M., Spallino, A., Falchi, M., Bertelli, A., Morelli, R., Lo Scalzo, R., 2009. Antioxidant activity of Calendula officinalis extract: inhibitory effects on chemiluminescence of human neutrophil bursts and electron paramagnetic resonance spectroscopy. Pharmacology 83(6), 348-55.

Brand, C., Ferrante, A., Prager, R. H., Riley, T. V., Carson, C. F., Finlay-Jones, J. J., Hart, P. H., 2001. The water solublecomponents of the essential oil of Melaleuca alternifolia (tea tree oil) suppress the production of superoxide by human monocytes, but not neutrophils, activated in vitro. Inflamm. Res. 50, 213-219.

Brophy, J.J., Davies, N.W., Southwell, I.A., Stiff, I.A., Williams, L.R., 1989. Gas chromatographic quality control for oil of Melaleuca terpinen-4-ol type (Australian tea tree). J. Agric. Food Chem. 37, 1330-1335.

Caldefie-Chézet, F., Guerry, M., Chalchat, J. C.,Fusillier, C., Vasson, M. P., Guillot, J., 2004. Anti-inflammatory effects of Melaleuca alternifolia essential oil on human polymorphonuclear neutrophils and monocytes. Free Rad. Res. 38, 805-811.

Carson, C. F., Cookson, B. D., Farrelly, H. D., Riley, T.V., 1995. Susceptibility of methicillin-resistant Staphylococcus aureus to the essential oil of Melaleuca alternifolia. J. Antimicrob. Chemother. 35, 421-424.

Carson, C. F., Hammer, K. A., Riley, T.V., 2006. Melaleuca alternifolia (Tea Tree) Oil: a Review of Antimicrobial and Other Medicinal Properties. Clin. Microbiol. Rev. 19(1), 50 62.

Carson, C. F., Riley, T. V., 1993. Antimicrobial activity of the essential oil of Melaleuca alternifolia. Lett. Appl. Microbiol. $16,49-55$.

Carson, C. F., Riley, T. V., 1995. Antimicrobial activity of the major components of the essential oil of Melaleuca alternifolia. J. Appl. Bacteriol. 78, 264-269.

Chanchal, D., Swarnlata, S., 2008. Novel approaches in herbal cosmetics. J. Cosmet. Dermatol. 7, 89-95.

Chandran, P.K., Kuttan, G., Kuttan, R., 2009. Anti-inflammatory activity of flower extract of Calendula officinalis Linn. and its possible mechanism of action. Indian J. Exp. Biol. 47(2), 113-20.

Chandran, P.K., Kuttan, R., 2008. Effect of Calendula officinalis Flower Extract on Acute Phase Proteins, Antioxidant Defense Mechanism and Granuloma Formation During Thermal Burns. J. Clin. Biochem. Nutr. 43(2), 58-64.

Charnock, J.S., 2000. Gamma-linolenic acid provides additional protection against ventricular fibrillation in aged rats fed linoleic acid rich diets. Prostaglandins Leukot Essent Fatty Acids 62(2), 129-134.

Christoph, F., Kaulfers, P.M., Stahl-Biskup, E., 2000. A comparative study of the in vitro antimicrobial activity of tea tree oils s.l. with special reference to the activity of betatriketones. Planta Med. 66(6), 556-560.

Coffey, T., 1993. The history and folklore of North American wildflowers, pp. 356, Accessed at: http://klemow.wilkes.edu/ Oenothera.html

Community herbal monograph on Viola tricolor L. and/or subspecies Viola arvensis Murray (Gaud) and Viola vulgaris Koch (Oborny), herba cum flore (2010), Committee on Herbal Medicinal Products (HMPC), European Medicines Agency, Accessed at: http://www.ema.europa.eu/docs/ en_GB/document_library/Herbal___Community_herbal_ monograph/2011/01/WC500101197. $\overline{\text { pdf }}$

Cox, S.D., Mann, C.M., Markham, J.L., Beli, H.C., Gustafson, J.E., Warmington, J.R., Wyllie, S.G., 2000. The mode of antimicrobial action of the essential oil of Melaleuca alternifolia (tea tree oil). Journal of Applied Microbiology $88,170-175$.

Darben, T., Cominos, B., Lee, C.T., 1998. Topical eucalyptus oil poisoning. Australas. J. Dermatol. 39, 265-267.

De La Cruz, J.P, Martin-Romero M, Carmona JA, Villalobos MA, Sanchez de la Cuesta F., 1997. Effect of evening primrose oil on platelet aggregation in rabbits fed an atherogenic diet. Thromb Res 87(1), 141-149.

De La Cruz, J.P., Quintero, L., Galvez, J., Villalobos, M.A., Sanchez de la Cuesta, F., 1999. Antioxidant potential of evening primrose oil administration in hyperlipemic rabbits. Life Sciences 65(5), 543-555.

Della Loggia, R., Tubaro, A., Sosa S., Becker, H., Saar, S., Isaac, O., 1994. The role of triterpenoids in the topical antiinflammatory activity of Calendula officinalis flowers. Planta 
Med. 60 (6), 516-520.

Deters, A., Dauer, A., Schnetz, E., Fartasch, M., Hensel, A., 2001. High molecular compounds (polysaccharides and proanthocyanidins) from Hamamelis virginiana bark: influence on human skin keratinocyte proliferation and differentiation and influence on irritated skin. Phytochemistry 5(6), 949-958.

Deters, A.M., Lengsfeld, C., Hensel, A., 2005. Oligo- and polysaccharides exhibit a structure-dependent bioactivity on human keratinocytes in vitro. J Ethnopharmacol. 102(3), 391-399.

Dey, B.B., Choudhari, M.A., 1984. Essential oil of Ocimum sanctum L. and its antimicrobial activity. ABIM (An Annotated Bibliography of Indian Medicine), 28(2), 82-87.

Dirks, J., van Aswegen, C.H., du Plessis, D.J., 1998. Cytokine levels affected by gamma-linolenic acid. Prostaglandins Leukot Essent Fatty Acids 59(4), 273-277.

Dreno, B., Bettoli V, Ochsendorf, F., Perez-Lopez, M., Mobacken, H., Degreef, H., Layton, A., 2006. An expert view on the treatment of acne with systemic antibiotics and/or oral isotretinoin in the light of the new European recommendations. Eur. J. Dermatol. 15, 565-571.

Egwaikhide, P.A., Okeniyi, S.O., Akporhonor, E.E., Emua S.A., 2008. Studies on Bioactive metabolites constituents and antimicrobial evaluation of leaf extracts of Eucalyptus globulus. Agricultural Journal (med well Journals) 3(1), 4245.

Engel, R., Gutmann, M., Hartisch, C., Kolodziej, H., Nahrstedt, A., 1998. Study on the composition of the volatile fraction of Hamamelis virginiana. Planta Med. 64(3), 251-253.

Enshaieh, S., Jooya, A., Siadat, A.H., Iraji, F., 2007. The efficacy of $5 \%$ topical tea tree oil gel in mild to moderate acne vulgaris: a randomized, double-blind placebo-controlled study. Indian J. Dermatol. Venereol. Leprol., 73(1), 22-25.

Erdelmeier, C.A.J., Ciantl, J. Jr., Rabenau, H., Doerr, H.W., Biber, A., Koch, E., 1996. Antiviral and Antiphlogistic Activities of Hamamelis virginiana Bark. Planta Med. 62(3), 241-245.

Eucalyptus globulus extract, Accessed at: http://www.herbextract.com/plant-extract/563839.html.

Fang, C., Jiang, Z., Tomlinson, D.R., 1997. Expression of constitutive cyclo-oxygenase (COX-1) in rats with streptozotocin-induced diabetes effects of treatment with evening primrose oil or an aldose reductase inhibitor on COX-1 mRNA levels., Prostaglandins Leukot Essent Fatty Acids 56(2), 157-163.

Folium et Cortex Hamamelidis, WHO Monograph on Selected Medicinal Plants, volume 2, WHO, Geneve, 2004, pp. 124136.

Gardiner, P., 2000. Chasteberry (Vitex agnus castus). Longwood Herbal Task Force: http://www.mcp.edu/herbal/default.htm

Gentil, M., Pereira, J.V., Corrêa Silva Sousa, J.T., Pietro, R., Sousa Neto, M.D., Vansan, L.P., de Castro França, S., 2006. In vitro evaluation of the antibacterial activity of Arctium lappa as a phytotherapeutic agent used in intracanal dressings. Phytotherapy Research 20(3), 184-186.

Ghalem, B.R., Mohamed, B., 2008. Antibacterial activity of leaf essential oils of Eucaliptus globulus and Eucaliptus camaldulensis. African Journal of Pharmacy and Pharmacology 2(10), 211-215.

Godhwani, S., Godhwani, J.L., Vyas, D.S., 1987. Ocimum sanctum: an experimental study evaluating its antiinflammatory, analgesic and antipyretic activity in animals. J. Ethnopharmacol. 21, 153-163.
Gollnick, H., Krautheim, A., 2003. Topical treatment in acne: Current status and future aspects. Dermatology 206(1), 2936.

Gollnick, H.P., Finlay, A.Y., Shear, N., 2008. Global alliance to improve outcomes in acne. Can we define acne as a chronic disease? If so, how and when? Am. J. Clin. Dermatol. 9, 279-284.

Gupta, P., Yadav, D.K., Siripurapu, K.B., Palit, G., Maurya, R., 2007. Constituents of Ocimum sanctum with Antistress Activity, J. Nat. Prod. 70(9), 1410-1416.

Hammer, K. A., Carson, C. F., Riley, T.V., 1996. Susceptibility of transient and commensal skin flora to the essential oil of Melaleuca alternifolia (tea tree oil). Am. J. Infect. Control 24, 186-189.

Hammer, K.A., Carson, C.F., Riley, T.V., 2002. In vitro activity of Melaleuca alternifolia (tea tree) oil against dermatophytes and other filamentous fungi. J. Antimicrob. Chemother. 50(2), 195-199.

Hammer, K.A., Carson, C.F., Riley, T.V., Nielsen, J.B., 2006. A review of the toxicity of Melaleuca alternifolia (tea tree) oil. Food Chem. Toxicol. 44(5), 616-625.

Hammer, K.A., Carson, C.F., Ruiley, T.V., 2003. Antifungal activity of the components of Melaleuca alternifolisa (tea tree) oil. Journal of Aplied Microbiology 95, 853-860.

Harkenthal, M., Reichling, J., Geiss, H.K., Saller, R., 1999. Comparative study on the in vitro antibacterial activity of Australian tea tree oil, cajuput oil, niaouli oil, manuka oil, kanuka oil, and eucalyptus oil. Pharmazie 54(6), 460-463.

Hart, P. H., Brand, C., Carson, C. F., Riley, T. V., Prager, R. H., Finlay-Jones, J.J., 2000. Terpinen-4-ol, the main component of the essential oil of Melaleuca alternifolia (tea tree oil), suppresses inflammatory mediator production by activated human monocytes. Inflamm. Res. 49, 619-626.

Hartisch, C., Kolodziej, H., von Bruchhausen, F., 1997. Dual inhibitory activities of tannins from Hamamelis virginiana and related polyphenols on 5-lipoxygenase and lyso-PAF: acetyl-CoA acetyltransferase. Planta Med. 63(2), 106-110.

Hederos, C.A., Berg, A., 1996. Epogam evening primrose oil treatment in atopic dermatitis and asthma. Arch. Dis. Child. 75(6), 494-497.

Homer, L. E., Leach, D. N., Lea, D., Lee, L. S., Henry, R. J., Baverstock P. R., 2000. Natural variation in the essential oil content of Melaleuca alternifolia Cheel (Myrtaceae). Biochem. Syst. Ecol. 28, 367-382.

Horrobin, D.F., 2000. Essential fatty acid metabolism and its modification in atopic aczema. Am. J. Clin. Nut. 71(1), 3675-3725.

How Effective Is Evening Primrose Oil for Acne? Accessed at: http://www.wisegeek.com/how-effective-is-eveningprimrose-oil-for-acne.htm

http://www.herbs2000.com/herbs/herbs_evening_primrose.htm Evening primrose (Oenothera biennis). Last accessed on January 10, 2009.

Ismail, M.F., El-Maraghy, S.A., Sadik, N.A.H., 2008. Study of the immunomodulatory and anti-inflamatory effects of evening primrose oil in adjuvant arthritis. African J. Biochem. Res. 2(3), 74-80.

Jacob, C.I., Dover, J.S., Kaminer, M.S., 2001. Acne scarring: a classifi cation system and review of treatment options. J. Am. Acad. Dermatol. 45, 109-117.

Kelm, M.A., Nair, M.G., Strasburg, G.M., DeWitt, D.L., 2000. Antioxidant and cyclooxygenase inhibitory phenolic 
compounds from Ocimum sanctum Linn. Phytomedicine $7(1), 7-13$.

Khalil, Z., Pearce, A.L., Satkunanathan, N., Storer, E., FinlayJones, J.J., Hart, P.H., 2004. Regulation of whealand flare by tea tree oil: complementary human and rodent studies. J. Investig. Dermatol. 123, 683-690.

Klövekorn, W., Tepe, A., Danesch, U., 2007. A randomized, double-blind, vehicle-controlled, half-side comparison with a herbal ointment containing Mahonia aquifolium, Viola tricolor and Centella asiatica for the treatment of mild-tomoderate atopic dermatitis. Int $\mathrm{J}$ Clin Pharmacol Ther. 45(11), 583-591.

Koh, K.J., Pearce, A.L., Marshman, G., Finlay-Jones, J.J., Hart, P.H., 2002. Tea tree oil reduces histamine-induced skin inflammation. Br. J. Dermatol. 147, 1212-1217.

Kulkarni, R.R., Virkar, A.D., D'Mello, P., 2008. Antioxidant and anti-inflammatory activity of Vitex negundo. Indian J. Pharm. Sci. 70, 838-840.

Kurokawa, I., Danby, F.W., Ju, Q., Wang, X., Xiang, L.F., Xia, L., Chen, W., Nagy, I., Picardo, M., Suh, D.H., Ganceviciene, R., Schagen, S., Tsatsou, F., Zouboulis, C.C., 2009. New developments in our understanding of acne pathogenesis and treatment. Experimental Dermatology 18, 821-832.

Kumar, A., Baboota, S., Agarwal, S.P., Ali, J., Ahuja, A., 2008. Treatment of acne with special emphasis on herbal remedies. Expert. Rev. Dermatol. 3, 111-122.

Lauk, L., Lo Bue, A.M., Milazzo, I., Rapisarda, A., Blandino, G., 2003. Antibacterial activity of medicinal plant extracts against periodontopathic bacteria. Phytotherap. Res. 17(6), 599-604.

Leyden, J.J., 2001. The evolving role of Propionibacterium acnes in acne. Semin. Cutan. Med. Surg. 20, 139-143.

Lin, C.C., Lu, J.M., Yang, J.J., Chung, S.C., Ujiie, T., 1996. Antiinflamatory and radical scavenging effects of Arctium lappa. Am. J. Chin. Med. 24(2), 127-137.

Lis-Balchin, M., Hart, S.L., Deans, S.G., 2000. Pharmacological and antimicrobial studies on different tea-tree oils (Melaleuca alternifolia, Leptospermum scoparium or Manuka and Kunzea ericoides or Kanuka), originating in Australia and New Zealand. Phytother. Res. 14(8), 623-629.

Low, D., Rawal, B. D., Griffin, W. J., 1974. Antibacterial action of the essential oils of some Australian Myrtaceae with special references to the activity of chromatographic fractions of oil of Eucalyptus citriodora. Planta Med. 26, 184-189.

Lucky, A.W., 1998. A review of infantile and pediatric acne. Dermatology 196, 95-97.

Main constituents of Arctium lappa L., Accessed at: http://www. google.com/imgres?imgurl=http://www.medicinescomplete. com/mc/herbals/current/images/HrbburdockC001_default. png\&imgrefurl=http://www.medicinescomplete.com $/ \mathrm{mc} /$ herbals/current/HBL100072

Mantle, D., Eddeb, F., Pickering, A.T., 2000. Comparison of relative antioxidant activities of British medicinal plant species in vitro. J. Ethnopharmacol. 72(1-2), 47-51.

Meixner, D., Schneider, S., Krause, M., Sterry, W., 2008. Acne inversa. J. Dtsch. Dermatol. Ges. 6, 189-196.

Messager, S., Hammer, K.A., Carson, C.F., Riley, T.V., 2005. Assessment of the antibacterial activity of tea tree oil using the European EN1276 and EN12054 standard suspension tests. J Hosp Infect. 59, 113-125.

Momin, S., Peterson, A., del Rosso, J.Q., 2009. Drug-induced acneform eruptions: definitions

Mondal, S., Mahapatra, S.C., Mirdha, B.R., Naik, S.N., 2007.
Antimicrobial activities of essential oils obtained from fresh and dried leaves of Ocimum sanctum (L.) against enteric bacteria and yeast. Acta Hort. (ISHS) 756, 267-270.

Mondal, S., Mirdha, B.R., Mahapatra, S.C., 2009. The Science Behind Sacredness of Tulsi (Ocimum sanctum Linn.). Indian J. Physiol. Pharmacol. 53(4), 291-306.

Morelli, J. G., 2007. Acne, in Kliegman, R.M., Behrman, R.E., Jenson, H.B., Stanton, B.F., (Eds.), Nelson textbook of pediatrics 18th ed., Philadelphia, PA: Saunders Elsevier, pp. 2759-2764

Morse, N.L., Clough, P.M., 2006. A meta-analysis of randomized, placebo-controlled clinical trials of Efamol evening primrose oil in atopic eczema. Where do we go from here in light of more recent discoveries? Curr. Pharm. Biotechnol. 7(6), 503-524.

Muley, B.P., Khadabadi, S.S., Banarase, N.B., 2009. Phytochemical Constituents and Pharmacological Activities of Calendula officinalis Linn (Asteraceae): A Review. Tropical Journal of Pharmaceutical Research 8(5), 455-465.

Naved, T., Ansari, S.H., Mukhtar, H.M., Ali, M., 2005. New triterpene esters of oleanene-sreies from the flowers of Calendula officinalis Linn. Indian Journal of Chemistry 44B, 1088-1091.

Oberemok, S.S., Shalita, A.R., 2002.Acne vulgaris, II: Treatment. Cutis 70(2), 111-114.

Olutunmbi, Y., Paley, K., English, J.C., 2008. Adolescent Female Acne: Etiology and Management. Journal of Pediatric and Adolescent Gynecology 20(4), 171-176.

Park, S.Y., Hong, S.S., Han, X.H., Hwang, J.S., Lee, D., Ro, J.S., Hwang, B.Y., 2007. Lignans from Arctium lappa and their inhibition of LPS-induced nitric oxide production. Chem. Pharm. Bull. 55, 150-152.

Pereira, J.V., Bergamo, D.C., Pereira, J.O., França Sde, C., Pietro, R.C., Silva-Sousa, Y.T., 2005. Antimicrobial activity of Arctium lappa constituents against microorganisms commonly found in endodontic infections. Braz Dent J. 16(3), 192-196.

Plewig, G., Jansen, T., 1998. Acneiform dermatoses. Dermatology 196, 102-107.

Prakash, P., Gupta, N., 2005. Therapeutic uses of Ocimum sanctum Linn. (Tulsi) with a note on eugenol and its pharmacological actions: a short review. Indian J. Physiol. Pharmacol. 49(2), 125-131.

Preethi, K.C., Kutan, G., Kuttan, R., 2009. Anti-inflammatory activity of flower extract of Calendula officinalis Linn. and its possible mechanism of action. Indian Journal of Experimental Biology 47, 113-120.

Raman, A., Weir, U., Bloomfield, S. F.. 1995. Antimicrobial effects of tea-tree oil and its major components on Staphylococcus aureus, Staph. epidermidis and Propionibacterium acnes. Lett. Appl. Microbiol. 21, 242-245.

Raman, A., Weir, U., Bloomfield, S.F., 1995. Antimicrobial effects of tea-tree oil and its major components on Staphylococcus aureus, Staph. epidermidis and Propionibacterium acnes. Letters in Applied Microbiology 21, 242-245.

Ramos-e-Silva, M., Coelho Carneiro, S.C., 2009. Acne Vulgaris: Review and Guidelines. Dermatology Nursing 21(2), 63-68.

Reed, M.J., Franks, S., 1988. Anti-androgens in gynaecological practice. Baillieres Clin. Obstet. Gynaecol. 2(3), 581-595.

Rivera, A.E., 2008. Acne scarring: a review and current treatment modalities. J. Am. Acad. Dermatol. 59, 659-676.

Russo, M., Galletti, G.C., 1996. Medicinal properties and chemical composition of Vitex agnus-castus L.: a review. 
Acta Hort. (ISHS) 426, 105-112.

Sagareishvili, T.G., Yarosh, E.A., Kemertelidze, E.P., 1999. Phenolic compounds from leaves of Hamamelis virginiana. Chem Nat Comps (Transl Khim Prir Soed) 35(5), 585.

Salari, M.H., Amine, G., Shirazi, M.H., Hafezi, R., Mohammadypour, M., 2006. Antibacterial effects of Eucalyptus globulus leaf extract on pathogenic bacteria isolated from specimens of patients with respiratory tract disorders. Clinical Microbiology and Infection 12, 194196.

Sanapati, S., Benerjee, S., Gangopadhyay, D.N., 2008. Evening primrose oil is effective in atopic dermatitis: a randomized placebo-controlled trial. Indian J. Dermatol. Enereol. Leprol. 74 (5), 447-452.

Sathiamoorthy, P., Gupta, P., Kumar, M., Chaturvedi, A.K., Shukla, P.K., Maurya, R., 2007. New antifungal flavonoid glycoside from Vitex negundo. Bioorganic Med. Chen. Lett. $17,239-242$.

Shalita, A.R., 2004. Acne: clinical presentations. Clin. Dermatol. 22, 385-386.

Shaukat, M., Huma, S., Umbreen, F., Arfa, K., Ghazala, H. R., 2009. Antifungal activities of Vitex negundo Linn., Pak. J. Bot. 41(4), 1941-1943.

Silva, J., Abebe, W., Sousa, S.M., Duarte, V.G., Machado, M.I., Matos, F.J., 2003. Analgesic and anti- inflammatory effects of essential oils of Eucalyptus. J Ethnopharmacol. 89(2-3), 277-283.

Singh, S., 1998. Comparative evaluation of antiinflammatory potential of fixed oil of different species of Ocimum and its possible mechanism of action. Indian J. Exp. Biol. 36, 10281031.

Singh, S., Agarwal, S.S., 1991. Anti-Asthmatic and AntiInflammatory Activity of Ocimum sanctum. Pharmaceutical Biology 29(4), 306-310.

Singh, S., Majumdar, D.K., 1995. Anti-inflammatory and antipyretic activities of Ocimum sanctum fixed oil. Pharmaceutical Biology 33, 288-292.

Singh, S., Majumdar, D.K., 1997. Evaluation of anti-inflammatory activity of fatty acids of Ocimum sanctum fixed oil. Indian J. Exp. Biol. 35, 380-383.

Singh, S., Majumdar, D.K., Rehan, H.M.S., 1996. Evaluation of anti-inflammatory potential of fixed oil of Ocimum sanctum (holy basil) and its possible mechanism of action. J. Ethanopharmacol. 54, 19-26.

Singh, S., Nair, V., Jain, S., Gupta, Y.K., 2008. Evaluation of anti-inflammatory activity of plant lipids containing alphalinolenic acid. Indian J. Exp. Biol. 46(6), 453-456.

Singh, S., Taneja, M., Majumdar, D.K., 2007. Biological activities of Ocimum sanctum L., fixed oil - an overview. Indian Journal of Experimental Biology 45, 403-412.

Tabanca, N., Kirimer, N., Demirci, B., Demirci, F., Baser, K.H.C., 2001. Composition and antimicrobial activity of the essential oils of Micromeria cristata subsp. Phyrgia and the enantiomeric distribution of borneol. Journal of Agricultural and Food Chemistry 49, 4300-4303.

Takahashi, T., Kokubo, R., Sakaino, M., 2004. Antimicrobial activities of eucalyptus leaf extracts and flavonoids from Eucalyptus maculata. Lett. Appl. Microbiol. 39, 60-64.

Tea-tree oil, Accessed at: http://chemicalland21.com/lifescience/ foco/TEA\%20TREE\%20OIL.htm

Thakur, K., Pitre, K.S., 2009. Anti0infklammatory activity of extracted eugenol from Ocimum sanctum L. leaves, Rasayan J. Chem, 2(2), 472-474.
Thiboutot, D., Gollnick, H., Bettoli, V., Dréno, B., Kang, S., Leyden, J.J., Shalita, A.R., Lozada, V.T., Berson, D., Finlay, A., Goh, C.L., Herane, M.I., Kaminsky, A., Kubba, R., Layton, A., Miyachi, Y., Perez, M., Martin, J.P., Ramos-ESilva, M., See, J.A., Shear, N., Wolf, J., Global Alliance to Improve Outcomes in Acne, 2009. New insights into the management of acne: an update from the Global Alliance to Improve Outcomes in Acne Group. J. Am. Acad. Dermatol. 60(5), S1-S50.

Toiu, A., Pârvu, A.E., Oniga, I., Tămaş, M., 2007. Evaluation of anti-inflammatory activity of alcoholic extract from Viola tricolor, Rev. Med. Chir. Soc. Med. Nat. Iasi. 111(2), 525-9.

Tourino, S., Lizarraga, D., Carreras, A., Lorenzo, S., Ugartondo, V., Mitjans, M., Vinardeli, M.P., Julia, L., Cascante, M., Torres, J.L., 2008. Highly galloylated tannin fractions from witch hazel (Hamamelis virginiana) bark: electron transfer capacity, in vitro antioxidant activity, and effects on skinrelated cells. Chem. Res. Toxicol. 21(3), 696-704.

Ukiya, M., Akihisa, T., Yasukawa, K., Tokuda, H., Suzuki, T., Kimura, Y., 2006. Anti-inflamatory, anti-timor-promoting, and cytotoxic activities of constituents of marigold (Calendula officinalis) flowers. J. Nat. Prod. 69(12), 1692-1696.

Usatine, R.P., Quan, M.A., 2000. Pearls in the management of acne: An advanced approach. Primary Care 27(2), 289-308.

Valeyrie-Allanore, L., Sassolas, B., Roujeau, J.C., 2007. Druginduced skin, nail and hair disorders. Drug Saf. 30, 10111030.

Vázquez, G., Fontenle, E., Santos, J., Freire, S.M., GonzálezÁlvarez, J., Antorrena, G., 2008. Antioxidantactivity and phenolic content of chestnut (Castanea sativa) shell and eucalyptus (Eucalyptus globulus) bark extracts. Industrial Crops and Products 28(3), 279-285.

Vennat, B., Pourrat, H., Pouget, M.P., Gross, D., Pourrat, A., 1992. Tannins from Hamamelis virginiana: Identification of Proanthocyanidins and Hamamelitannin Quantification in Leaf, Bark, and Stem Extracts. Planta Med. 54(5), 454-457.

Vidal-Oliver, E., Elias, R., Faure, F., Babadjamian, A., Crespin, F., Balansard, G., Boudon, G., 1989. Flavonol glycosides from Calendula officinalis flowers. Planta Med. 55(1), 73-74.

Viyoch, J., Pisutthanan, N., Faikreua, A., Nupangta, K., Wangtorpol, K., Ngokkuen, J., 2006. Evaluation of in vitro antimicrobial activity of Thai basil oils and their microemulsion formulas against Propionibacterium acnes. Int. J. Cosmet. Sci. 28(2), 125-133.

Vukics, V., Hevesi Toth, B., Ringer, T., Ludanyi, K., Kery, A., Bonn, G.K., Guttman, G., 2008a. Quantitative and qualitative investigation of the main flavonoids in heartsease (Viola tricolor L.). J Chromatogr. Sci. 46(2), 97-101.

Vukics, V., Kery, A., Guttman, A., 2008b. Analysis of polar antioxidants in Heartsease (Viola tricolor L.) and Garden pansy (Viola x wittrockiana Gams.). J. Chromatogr. Sci. 46(9), 823-827.

Vukics, V., 2009. Antioxidant flavonoid glycosides in Viola tricolor L. Theses of the Dissertation, Semmelweis University School of Pharmaceutical Sciences, Budapest, Hungary, Accessed at: http://phd.sote.hu/mwp/phd_live/vedes/export/ vukicsviktoria.e.pdf

Walsh, L. J., Longstaff, J., 1987. The antimicrobial effects of an essential oil on selected oral pathogens. Periodotology 8, 11-15.

Wang, H., Provan, G.J., Helliwell, K., 2003. Determination of hamamelitannin, catechins and gallic acid in witch hazel bark, twig and leaf by HPLC. Journal of Pharmaceutical and Biomedical Analysis 33(4), 539-544. 
Wang, H.Y., Yang, J.S., 1993. Studies on the chemical constituents of Arctium lappa L. Acta Pharmaceutica Sinica 28(12), 911917.

Williams, C., Layton, A.M., 2006. Treatment of acne: an update Expert Review of Dermatology 1(3), 429-438.

Williams, H.C., 2003. Evening primrose oil for atopic dermatitis, BMJ, 327, 1358. Accessed at: www.bmj.com/ content $/ 327 / 7428 / 1358$

Williams, L. R., Home, V.N., 1988. Plantation production of oil of melaleuca (tea tree oil) - a revitalised Australian essential oil industry. Search 19, 294-297.

Williams, L. R., Home, V.N., Asre, S., 1990. Antimicrobial activity of oil of melaleuca (tea tree oil). Its potential use in cosmetics and toiletries. Cosmet. Aerosols Toiletries Aust. 4, 12-13.

Williams, L. R., Home, V.N., Lusunzi, I., 1993. An evaluation of the contribution of cineole and terpinen-4-ol to the overall antimicrobial activity of tea tree oil. Cosmet. Aerosols Toiletries Aust. 7, 25-34.

Witkowska-Banaszczak, E., Bylka, W., Matławska, I., Goślińska, O., Muszyński, Z., 2005. Antimicrobial activity of Viola tricolor herb. Fitoterapia 76(5), 458-61.
Worm, M., Henz, B.M., 2000. Novel unconventional therapeutic approaches to atopic eczema. Dermatology 201(3), 191-195.

Yarnell, E., Abascal, K., 2006. Herbal Medicine for Acne Vulgaris. Alternative \& Complementary Therapies 12(6), 303-309.

Yoon, S., Lee, J., Lee, S., 2002. The therapeutic effect of evening primrose oil in atopic dermatitis patients with dry scaly skin lesions is associated with the normalization of serum gammainterferon levels. Skin Pharmacol. Appl. Skin Physiol. 15(1), 20-25.

Yoshimoto-Furuie, K., Yoshimoto, K., Tanaka, T., Saima, S., Kikuchi, Y., Shay, J., Horrobin, D.F., Echizen, H., 1999. Effects of oral supplementation with evening primrose oil for six weeks on plasma essential fatty acids and uremic skin symptoms in hemodialysis patients. Nephron 81(2), 151159.

Zaenglein, A.L., Thiboutot, D.M., 2006. Expert committee recommendations for acne management. Pediatrics, 118, 1188-1199.

Zhao, F., Wang, L., Liu, K., 2009. In vitro anti-inflamatory effects of asctigenin, a lignin from Arctium lappa L., trough inhibition on iNOS pathway. Journal of Ethnopharmacology $122,457-462$.

\title{
Резиме
}

\section{Фитотерапија на Acne vulgaris}

\section{Марија Главаш Додов ${ }^{1 *}$ и Светлана Кулеванова²}

\author{
${ }^{1}$ Институт за фармацевтска технологија, Фармацевтски факултет, Универзитет „Св. Кирил и Методиј”, \\ Скопје, Македонија \\ ${ }^{2}$ Институт за фармакогнозија, Фармацевтски факултет, Универзитет „, Св. Кирил и Методиј”, Скопје, \\ Македонија
}

Клучни зборови: Acne vulgaris, третман на акни, фитотерапија на акни

Acne vulgaris (акне) е една од најчестите дерматози во современото општество. Акне е хронична полиморфна болест на пилосебацеалните структури на кожата, што вклучува абнормалности во продукцијата на себум и се карактеризира со појава на инфламаторни (папули, пустули, нодуси) и неинфламаторни (отворени и затворени комедони) лезии. Propionibacterium acnes и Staphylococcus epidermidis ce значајни фактори во патогенезата на инфламаторните облици на акни, иако акне не претставува бактериска инфекција.

Денес на пазарот се присутни голем број лекови и козметички производи за третман на акни, при што се прифатени четири основни принципи: елиминирање на алтерираниот начин на кератини за цијанафоликулот, намалување на интрафоликуларната популација на Propionibacterium acnes или генерирањето на екстрацелуларните инфламаторни агенси и намалување на секрецијата на себум.

Третманот на акни вклучува локална и/или системска терапија, директна интралезиона терапија со кортикостероиди, фитотерапија и нивни комбинации. При локалната терапија најчесто се користат бензоил пероксид, локални антибиотици и ретиноидна киселина. Системската терапија опфаќа примена на антибиотици и орални ретиноиди. Изборот на третманот зависи од стадиумот на болеста, но истиот често е проследен со одредени несакани ефекти.

Во последните години, примената на хербалните преработки во третманот на акни добива сѐ поголема научна потврда и се смета како ефикасна алтернатива на конвенционалната терапија.

Целта на овој труд е да даде сѐопфатен преглед, базиран на научни докази, на растителните суровини и на фитопрепаратите со потврдена клиничка ефикасност што се користат во третманот на акни. 


\title{
Chemical characterization and antioxidant activity of Eryngium campestre L., Apiaceae from Kosovo
}

\author{
Flurim Nebija ${ }^{1}$, Gjoshe Stefkov², Marija Karapandzova², Trajche Stafilov ${ }^{3}$, \\ Tatjana Kadifkova Panovska², Svetlana Kulevanova ${ }^{2 *}$ \\ ${ }^{1}$ Faculty of Medicine - Section of Pharmacy, University of Prishtina, Prishtina, Kosovo \\ ${ }^{2}$ Faculty of Pharmacy, University Ss. Cyril and Methodius, Skopje, Republic of Macedonia \\ ${ }^{3}$ Institute of Chemistry, Faculty of Natural Sciences and Matemathics, University Ss. Cyril and Methodius, Skopje, Republic \\ of Macedonia
}

Received: November 2009; Accepted: December 2009

\begin{abstract}
This study is outlined to define the chemical composition and in vitro antioxidant activity of the extracts of aerial part and root of Eryngium campestre L. (Apiaceae) from Kosovo. Analysis of the chemical composition include determination of total ash, ash insoluble in hydrochloric acid, loss on drying and the content of water extract, as well as determination of flavonoids in aerial part and hemolytic activity of the root. The mineral composition ( $\mathrm{Zn}, \mathrm{Fe}, \mathrm{Cu}, \mathrm{Mn}, \mathrm{Ni}, \mathrm{K}, \mathrm{Co}, \mathrm{Pb}, \mathrm{Cd}$ and $\mathrm{Cr}$ ) in aerial parts and root has been studied using atomic absorption spectroscopy (AAS and ETAAS). Different part of E. campestre accumulate different amounts of investigated minerals. Antioxidant activity was determined by four various testing systems: DPPH assay, inhibition of production of hydroxyl radical, $\beta$-carotenebleaching assay, and inhibition of lipid peroxidation (TBA test). In DPPH system, ethanol extract of root of E. campestre exhibited higher radical-scavenging activity $\left(\mathrm{IC}_{50}=0.72 \mathrm{mg} \mathrm{ml}^{-1}\right)$ compared to the extract of the aerial part $\left(\mathrm{IC}_{50}=1.14 \mathrm{mg} \mathrm{ml}^{-1}\right)$. On the other hand, aerial part ethanol extract has exhibited stronger inhibition capacity on the production of hydroxyl radical in deoxyribose system than the root extract (50\% and 45\%, respectively). However, both ethanol extracts of $E$. campestre exhibited low antioxidant activity in $\beta$-carotenebleaching assay as well as, low capacity for inhibition of spontaneous lipid peroxidation in rat liver homogenate.
\end{abstract}

Key words: Eryngium campestre, flavonoids, mineral content, DPPH assay, antioxidant activity, $\beta$-carotene-bleaching test, TBA test.

\section{Introduction}

Eryngium campestre L. (Apiaceae) (field eryngo) is perennial plant, spread in Spain, France, Germany, Balkan Peninsula and other scattered localities in Europe, and in Africa and Asia as well (Ingram, 2006). It has been used in folk medicine as an infusion to treat cough, whooping cough, urinary infections, disturbed functions of kidney, increased urine secretion, eliminating out stones and sand from kidney and bladder, against water retaining and other conditions on urinary tract, for regulation of the function of prostate .

*svku@ff.ukim.edu.mk
The root of eryngo is known as antispasmodic, aromatic, diaphoretic, diuretic, expectorant, galactofuge and stimulant (Petkov, 1982). It promotes free expectoration and is very useful in the treatment of debility attendant on coughs of chronic standing in the advanced stages of pulmonary consumption. There are none known hazards of Eryngium campestre, even more young shoots and roots are edible parts of the plant which can be cooked and used as an asparagus substitute and as an easily digested vegetable (www.gardenzone.info).

The presence of bioactive secondary metabolites including saponins, phenolic acids, flavonoids, coumarins, essential oil, is considered to determine pharmacological 
activities of the plants of genus Eryngium, as well. Considering phenolics, flavonoids are the most investigated compounds. The literature data show that Eringium campestre contain glycosides of kaempferol, isorhamnetin, luteolin and quercetin (Karting and Wolf, 1993; Nebija et al. 2006) and flavanolacyl glycosides (Hohman et al. 1997) while the other representatives of the genus such as Eringium planum kaempferol and its glycosides (Stecka-Paszkiewez, 1983, Zarnack et al. 1977), E. maritimum contains glycosides of kaempferol, isoquercetin and astragalin (Hiller et al. 1981) and E. creticum glycosides of quercetin (Al-Khail, 1994). E. campestre contains coumarins (Erdelmeier and Sticher, 1985), D-mannitol (Asenov and Gevrenova, 1991), cyclohexanone and cyclohexadienone glycosides (Erdelmeier and Sticher, 1986). Similar components were identified in other species of Eryngium, for example acetilenes in E. creticum (El-Gamal et al. 1978) and coumarins in E. ilicifolium (Pinar and Galan, 1985). However, the most important class of secondary metabolites investigated in root of Eryngium campestre and other species of Eryngium were saponins. Thus, Kartal et al. were the first that had reported presence of two barringenol saponins in roots of $E$. campestre. These structures were elucidated by 2D NMR and mass spectrometry (Kartal et al. 2005). Five other saponins also glycosides of barringenol were reported one year latter (Kartal et al. 2006). Hiller at al. reported presence of eryngium saponins A, A1, A2 and B in root of E. planum (Hiller et al. 1972), then saponins of betulinic and oleanolic acids in $E$. bromelifolium (Hiller et al. 1974; 1976; 1978) and similar saponins in E. maritimum (Hiller et al. 1976). According to this, saponins were considered as the class of components responsible for anti-inflammatory effects of the root extract from $E$. campestre, but also for root and herb extracts of E. maritimum, E. kotschyi, E. creticum (Kupeli et al. 2006; Lisciani et al. 1984). Extracts of E. creticum could act beneficially against the hemolytic activities of snake and scorpion venoms (Alkohafi et al. 1997), while E. foetidum leaf extract acts as anticonvulsant, anti-inflammatory and analgesic agent (Simon and Singh, 1986; Saenz et al. 1998). Representatives of Eryngium species contain significant amounts of volatile oils and their oil composition and possible biological activity were investigated as well (Capetanos et al. 2007; Lerclercq et al. 1992; Pala-Paul et al. 2005; Pino et al. 1997a, 1997b; Wong et al. 1994). Finally, lypophylic extracts of species of genus Eryngium contain different phytosterols which are considered as important constituents for topical anti-inflammatory activity on acute and chronic inflammation models (Garcia et al. 1999).

Eryngium campestre is widely spread throughout the territory of Kosovo. Until now there is no data of chemical composition and biological activity of Eryngii herba or Eryngii radix originated from Kosovo. Having in mind all previously mentioned, the aim of the present research is determination of the chemical composition and possible antioxidant activity of different parts of Eryngium campestre from Kosovo.

\section{Experimental}

\section{Plant material}

The samples of the aerial parts in full blossom (Eryngii herba) were collected during summer in 2002 and 2003 on three different locations in Kosovo: 1) Prishtina, 2) Poduevo and 3) Lipljan. The roots (Eryngii radix) were collected at the same locations in autumn 2002 and 2003, as well. The samples were labeled with following marks for samples collected from 1) Prishtina, 2) Poduevo and 3) Lipljan, respectively:

- EH1/02, EH2/02 and EH3/02 for aerial plant material collected in 2002,

- EH1/03, EH2/03 and EH3/03 for aerial plant material collected in 2003,

- ER1/02, ER2/02 and ER3/02 for the roots collected in 2002 , and

- ER1/03, ER2/03 and ER3/03 for the roots collected in 2003 .

Herbarium voucher specimens with the same marks were deposited at the Institute of Botany, Section Pharmacy at the Faculty of Medicine in Prishtina, Kosovo. All samples were left to air dry and then put in a paper bags and stored at cool, dry and dark place, until analysis.

\section{Determination of basic chemical parameters}

The contents of total ash and ash insoluble in hydrochloric acid as well as the loss on drying were determined using methods described in European Pharmacopoeia $(\mathrm{Ph}$. Eur. 4). The content of total water extractive was determined by method in Ph. Jug. IV.

\section{Determination of flavonoids}

The content of flavonoids was determined in the samples of Eryngii herba by UV/Vis spectrophotometry, using $\mathrm{AlCl}_{3}$ as complexation reagent and method for determination of flavonoids described in Ph. Eur. 4. The spectrophotometer analysis was carried out in an Ultraviolet visible equipment (Perkin Elmer Lambda 16) at $425 \mathrm{~nm}$. The results were expressed in percentage of flavonoids, calculated as quercetin, from the average of six determinations, using the calibration curve of quercetin (concentration range $\left.0-100 \mu \mathrm{g} \cdot \mathrm{ml}^{-1} ; y=0,0103 x+0.0066, R^{2}=0.9993\right)$.

\section{Determination of hemolytic activity}

Haemolytic activity (expressed as HA) was evaluated for the root of Eryngium campestre by the method given in the Pharmacopoeia Jugoslavica (Ph. Jug. 4) using the Saponin-standard $(\mathrm{HA}=30000)$ as the reference substance. The value of hemolytic activity (SU/g) was calculated using following equation:

$$
\mathrm{HA}=\mathrm{a} \cdot \mathrm{c} / \mathrm{b} \cdot \mathrm{d}
$$


where: $\mathrm{a}=$ minimum volume $(\mathrm{ml})$ of saponin-standard solution that provoke total hemolysis; $b=$ minimum volume $(\mathrm{ml})$ of extract that provoke total hemolysis; $\mathrm{c}=\mathrm{mg}$ of saponin-standard in $100 \mathrm{ml}$ standard solution; $\mathrm{d}=\mathrm{g}$ of plant material in $100 \mathrm{ml}$ extract.

\section{Determination of mineral content}

Sample preparation. Microwave-assisted digestion in a Milestone Touch Control microwave digestion system was used for mineralization purposes. To $0.5 \mathrm{~g}$ herbal material $2 \mathrm{ml}$ of conc. $\mathrm{HNO}_{3}$ and $1 \mathrm{ml}$ of $30 \% \mathrm{H}_{2} \mathrm{O}_{2}$ were added and the mixture was subjected to microwave digestion with following program:

\begin{tabular}{cccc}
\hline \hline Step & Temperature $/{ }^{\circ} \mathrm{C}$ & Duration $/$ min & Power $/ \mathrm{W}$ \\
\hline 1 & 180 & 10 & 800 \\
2 & 180 & 15 & 800 \\
\hline
\end{tabular}

After cooling, the obtained solution was transferred into $50 \mathrm{ml}$ volumetric flask and filed up with $4 \% \mathrm{HNO}_{3}$. With each set of digested samples, a blank sample was run through the digestion procedure.

Instrumentation condition. Macroelements were determined by atomic absorption spectrometry (AAS). A Varian SpectrAA 640Z Zeeman electrothermal atomic absorption spectrophotometer with a Varian PSD-100 Autosampler and Varian SpectrAA 880 with deuterium correction (for flame determination) were used. Hollow cathode lamps were used as a source. Operating conditions for the determination of $\mathrm{Pb}, \mathrm{Co}, \mathrm{Ni}, \mathrm{Cr}, \mathrm{Fe}, \mathrm{Mn}, \mathrm{Na}, \mathrm{K}, \mathrm{Cd}$ and $\mathrm{Zn}$ are given in Tables 1 and 2 .

\section{Determination of the radical scavenging and antioxidant} activity

Sample preparation. Dried powdered plant material (10 g) was extracted by continual mixing in $100 \mathrm{ml}$

Table 1. Instrumental parameters for determination of $\mathrm{Na}, \mathrm{K}, \mathrm{Ni}, \mathrm{Fe}, \mathrm{Mn}, \mathrm{Cu}$ and $\mathrm{Zn}$ by flame AAS

\begin{tabular}{cccc}
\hline \hline Element & Wavelenght, nm & Slit, nm & Lamp current, $\mathrm{mA}$ \\
\hline $\mathrm{Na}$ & 589.0 & 0.2 & 5 \\
$\mathrm{~K}$ & 766.5 & 1.0 & 5 \\
$\mathrm{Ni}$ & 232.0 & 0.2 & 4 \\
$\mathrm{Fe}$ & 248.3 & 0.2 & 5 \\
$\mathrm{Mn}$ & 279.5 & 0.2 & 5 \\
$\mathrm{Cu}$ & 324.8 & 0.2 & 5 \\
$\mathrm{Zn}$ & 213.9 & 1.0 & \multicolumn{2}{c}{ Acetylene/air } \\
& Gas mixture & \multicolumn{2}{c}{} \\
\hline
\end{tabular}

Table 2. Optimal parameters for $\mathrm{Co}, \mathrm{Ni}, \mathrm{Pb}, \mathrm{Cd}$ and $\mathrm{Cr}$ determination by Zeeman ETAAS

\begin{tabular}{|c|c|c|c|c|c|}
\hline Parameters & $\mathrm{Co}$ & $\mathrm{Ni}$ & $\mathrm{Pb}$ & $\mathrm{Cd}$ & $\mathrm{Cr}$ \\
\hline Wavelength, nm & 242.5 & 232.0 & 283.3 & 228.8 & 357,9 \\
\hline Slit, nm & 0.2 & 0.2 & 0.5 & 0.5 & 0.5 \\
\hline Lamp current, $\mathrm{mA}$ & 7.0 & 4.0 & 5.0 & 4.0 & 7.0 \\
\hline Calibration mode & \multicolumn{5}{|c|}{ Absorbance, peak hight } \\
\hline GAS & \multicolumn{5}{|c|}{ Argon } \\
\hline DRYING & & & & & \\
\hline Temperature $\left({ }^{\circ} \mathrm{C}\right)$ & 120 & 120 & 120 & 120 & 120 \\
\hline Ramp time (s) & 45 & 45 & 45 & 45 & 45 \\
\hline Hold time (s) & 10 & 10 & 10 & 10 & 10 \\
\hline \multicolumn{6}{|l|}{ CHARING } \\
\hline Temperature $\left({ }^{\circ} \mathrm{C}\right)$ & 750 & 800 & 400 & 250 & 100 \\
\hline Ramp time (s) & 5 & 6 & 5 & 5 & 5 \\
\hline Hold time (s) & 32 & 2 & 32 & 2 & 3 \\
\hline \multicolumn{6}{|l|}{ ATIMIZING } \\
\hline Temperature $\left({ }^{\circ} \mathrm{C}\right)$ & 2300 & 2400 & 2100 & 1800 & 2500 \\
\hline Ramp time (s) & 1.1 & 1 & 1 & 0.7 & 1.2 \\
\hline Hold time (s) & 2 & 2 & 2 & 0 & 2 \\
\hline \multicolumn{6}{|l|}{ CLEANING } \\
\hline Temperature $\left({ }^{\circ} \mathrm{C}\right)$ & 2300 & 2400 & 2100 & 1800 & 2500 \\
\hline Hold time (s) & 2 & 2 & 2 & & 2 \\
\hline
\end{tabular}

* Program for steps 1-3 is the same for all elements 
ethanol:water $(7: 3, \mathrm{~V} / \mathrm{V}), 24 \mathrm{~h}$ at room temperature. After filtration, filtrate was evaporated until dry. The residues were dissolved in $96 \%$ ethanol to obtained solution with concentration $0.1 \mathrm{~g} \mathrm{ml}^{-1}$.

Reagent and standrads. The standards of quercetin and BHA (butyl hydroxyl anisole) were purchased from Extrasynthese, Lyon, France. All other chemicals were of reagent grade and were used without further purification.

Assesment of the free radical scavenging activity in 1,1-diphenyl-2-picrylhydrazyl radical (DPPH) assay. The antioxidant activity using the DPPH assay was assessed by the method of Tagashira and Ohtake (1998). A test sample solution (plant extract) $(200 \mu \mathrm{l})$ was added to $4 \mathrm{ml}$ of $100 \mathrm{mmol} \mathrm{l}^{-1}$ ethanolic DPPH. After vortexing, the mixture was incubated for 10 minutes at room temperature and the absorbance was measured at $517 \mathrm{~nm}$. The differences in absorbance between a test sample and a control (ethanol) was considered as an activity. The activity was shown as $\mathrm{IC}_{50}$ value. Quercetin and BHA (100 mg ml- in ethanol) were used as reference substances. All values are shown as a mean value of the three measurements.

Assesment of the hydroxyl radical scavenging activity. Hydroxyl radical scavenging activity was carried out by measuring the competition between deoxyribose and the plant extracts for hydroxyl radicals generated from the $\mathrm{Fe}^{3+} /$ ascorbate/EDTA $/ \mathrm{H}_{2} \mathrm{O}_{2}$ system. The attack of the hydroxyl radical on deoxyribose leads to TBARS (thiobarbituric acid-reactive substances) formation (Haliwell and Gutteridge, 1981). The extracts were added to the reaction mixture containing $2.8 \mathrm{mmol} \mathrm{l}^{-1}$ deoxyribose, $100 \mathrm{mmol} \mathrm{l}^{-1}$ $\mathrm{FeCl}_{3}, 104 \mathrm{mmol} \mathrm{l}^{-1}$ EDTA, $100 \mathrm{mmol} \mathrm{l}^{-1}$ ascorbic acid, 1 mmol l-1 $\mathrm{H}_{2} \mathrm{O}_{2}$ and $230 \mathrm{mmol} \mathrm{l}^{-1}$ phosphate buffer ( $\mathrm{pH}$ 7.4), making up a final volume of $1.0 \mathrm{ml}$. In the series of control experiments reference substances, such as quercetin and BHA (100 mg ml-1 in phosphate buffer-pH 7.4), were used instead of the extracts. The reaction mixture was incubated at $37^{\circ} \mathrm{C}$ for $1 \mathrm{~h}$. The formed TBARS were measured by the method given by Ohkawa et al. (1979). One ml of thiobarbituric acid TBA (1\%) and $1.0 \mathrm{ml}$ trichloroacetic acid (TCA 2.8\%) were added to the tested tube and were incubated at $100{ }^{\circ} \mathrm{C}$ for $20 \mathrm{~min}$. After cooling, absorbance was measured at $532 \mathrm{~nm}$ against a blank containing deoxyribose and buffer. Reactions were carried out in triplicate.

Assesment of antioxidant activity. The antioxidant activity of the plant extracts was evaluated using $\beta$-carotenebleaching assay (Wanasundara et al. 1994). A solution of $\beta$-carotene was prepared by dissolving $2.0 \mathrm{mg}$ of $\beta$-carotene in $10 \mathrm{ml}$ chloroform. One $\mathrm{ml}$ of this solution was pipetted into a round-bottom flask. When chloroform was rotary evaporated at $40{ }^{\circ} \mathrm{C}$ under vacuum, $20 \mathrm{mg}$ of purified linoleic acid, $200 \mathrm{mg}$ of Tween 40 emulsifier and $50 \mathrm{ml}$ of distilled water were added to the flask with vigorous shaking. Aliquots $(5 \mathrm{ml})$ of this emulsion were transferred into a series of tubes containing $2 \mathrm{mg}$ of each plant extract or
$2 \mathrm{mg}$ of BHA (butylated hydroxyanisole) or $2 \mathrm{mg}$ of quercetin, for comparison. Aliquots $(5 \mathrm{ml})$ of emulsion without any further additions were used as control. As soon as the emulsion was added to each tube, the zero time absorbance was read at $470 \mathrm{~nm}$. Subsequent absorbance readings were recorded at 10-min intervals by keeping the sample in a water bath at $50{ }^{\circ} \mathrm{C}$ until the visual color of $\beta$-carotene in the control sample had disappeared (about $120 \mathrm{~min}$ ).

Assesment of the capacity of inhibition of spontaneous lipid peroxidation (LP). The quantitative measurement of lipid peroxidation was done by measuring the concentration of thiobarbituric acid reactive substances (TBARS) in liver homogenate using the method of Ohkawa et al. (1979). The amount of formed malondialdehyde (MDA) was quantitated by reaction with thiobarbituric acid and used as a measure of lipid peroxidation. The results were expressed as nmol MDA.mg-1 protein. The content of protein was determined according to the method of Bradford using bovine serum albumin as a standard (Bradford, 1976).

Preparation of liver homogenate. The rat livers were exposed, dissected free from extraneous tissues, rinsed with chilled $1.15 \% \mathrm{KCl}$ solution $(\mathrm{pH} 7.0)$ and $50 \%$ homogenate was prepared in $0.15 \mathrm{~mol} \mathrm{l}^{-1}$ sodium phosphate buffer ( $\mathrm{pH}$ 7.0). The homogenate was centrifuged at $3500 \mathrm{~g}$ for 10 minutes at $4{ }^{\circ} \mathrm{C}$ and the supernatant was used for the estimation of lipid peroxidation level.

Preparation of control: to $0.5 \mathrm{ml}$ of liver homogenate supernatant (LHS), $10 \mu \mathrm{H}_{2} \mathrm{O}$ and $4.5 \mathrm{ml}$ extractive solvent $\left(10 \mathrm{ml} 10 \% \mathrm{HClO}_{4}\right.$ saturated with TBA and $30 \mathrm{ml} 20 \%$ TCA) were added and heated on $95{ }^{\circ} \mathrm{C}$ for 20 minutes. After cooling, the mixture was centrifuged at $3500 \mathrm{~g}, 10 \mathrm{~min}-$ ute. Absorbance of transparent supernatant was measured on $532 \mathrm{~nm}$.

Preparation of test solution: to $0.5 \mathrm{ml}$ of liver homogenate supernatant (LHS), $10 \mu \mathrm{l}$ of plant extract (or reference substance solution) and $4.5 \mathrm{ml}$ extractive solvent were added and heated on $95{ }^{\circ} \mathrm{C}$ for 20 minutes. After cooling, the mixture was centrifuged at $3500 \mathrm{x} \mathrm{g}, 10$ minute. Absorbance of transparent supernatant was measured on $532 \mathrm{~nm}$.

The inhibition of lipid peroxidation (\%) was calculated using following equation:

$$
I \%=\frac{A_{o}-A_{u}}{A_{o}} \times 100
$$

$A_{o}$ - absorbance of control; $A_{u}$ - absorbance in presence of extract (reference substance).

The amounts of formed malondialdehyde (nmol MDA $\mathrm{mg}$ protein $^{-1}$ ) were calculated using following equation:

$$
c M D A=\frac{A}{\varepsilon} \times \frac{V_{u}}{V_{l}} \times 10^{-3} \times R
$$

A - absorbance; $\varepsilon$ - $156000 \mathrm{dm}^{3} / \mathrm{mol} ; \mathrm{V}_{\mathrm{u}}$ - volume before centrifugation; $\mathrm{V}_{1}$ - volume of LHS; $\mathrm{R}$ - dissolution rate. 


\section{Results and discussion}

\section{Basic chemical parameters}

The basic parameters important for assessment of quality of dried aerial part of Eryngium campestre from Kosovo (Eryngii herba) and roots (Eryngii radix) included determination of total ash, ash insoluble in hydrochloric acid and loss on drying (Table 3). The values of loss on drying ranged from 7.0 to $9.5 \%$ in herba and from $7.0-9.9 \%$ in radix. The amounts of total ash were lower in samples of herba (5.8-7.3\%) in comparison to those of radix (9.6$13.3 \%$ ). Samples of Eryngii herba had lower percentage of water extract (18.3-24.5\%) in comparison to the samples of Eryngii radix (29.6-36.6\%). Obtained results showed presence of larger amounts of possible active components in Eryngii radix. The amount of $8.41 \%$ total ash from the leaves of E. foetidisima are reported previously (Borah et al. 2009).

\section{Flavonoid content}

The results of determination of total flavonoid content in Eryngii herba are presented in Table 4. The percentages of total flavonoids $(0.12-0.14 \%)$ were expressed as total quercetin. Compared with literature data, the contents of total flavonoids were lower than those previously reported by other researchers. Thus, in dried aerial parts of E. planum, E. campestre and E. maritimum from Romania, total of $0.32-0.56 \%$ of flavonoids expressed as rutin were found (Suciu et al. 2006).

\section{Hemolytic activity}

The results of the evaluation of hemolytic activity of Eryngii radix are presented in Table 5. Obtained values were lower in comparison to the HA of some saponincontaining plants such as Saponaria officinalis (radix) (50 $\mathrm{SU} / \mathrm{g}$ ), Herniaria glabra (herba) (30 SU/g) or Primula ver-

Table 3. The levels of basic chemical parameters for assessment of quality of Eryngium herba and Eryngium radix, Eryngium campestre from Kosovo (\%)

\begin{tabular}{ccccc}
\hline \hline Sample & Loss on drying & Ash & Ash insoluble in hydrochlorid acid & Water extract \\
\hline EH1/02 & 7.5 & 6.6 & 1.9 & 24.2 \\
EH1/03 & 7.0 & 5.8 & 2.0 & 22.5 \\
EH2/02 & 7.6 & 6.6 & 1.7 & 18.8 \\
EH2/03 & 9.1 & 7.3 & 2.3 & 21.1 \\
EH3/02 & 7.7 & 5.8 & 1.5 & 21.8 \\
EH3/03 & 9.5 & 5.8 & 1.8 & 18.3 \\
ER1/02 & 8.9 & 10.7 & 1.9 & 36.6 \\
ER1/03 & 9.8 & 11.9 & 3.0 & 33.6 \\
ER2/02 & 7.0 & 13.0 & 2.5 & 31.6 \\
ER2/03 & 9.0 & 12.0 & 3.6 & 29.6 \\
ER3/02 & 9.9 & 13.3 & 4.8 & 34.7 \\
ER3/03 & 9.3 & 9.6 & 5.3 & 33.8 \\
\hline
\end{tabular}

$\mathrm{EH}$ - samples of Eryngii herba, ER - samples of Eryngii radix, $\mathrm{n}=3$.

Table 4. The content of total flavonoids in Eryngii herba, Eryngium campestre

\begin{tabular}{ccccccc}
\hline \hline & EH1/02 & EH2/02 & EH3/02 & EH1/03 & EH2/03 & EH3/03 \\
\hline$(\%) \pm$ Sd & $0.12 \pm 0.01$ & $0.14 \pm 0.01$ & $0.13 \pm 0.01$ & $0.13 \pm 0.03$ & $0.13 \pm 0.04$ & $0.14 \pm 0.03$ \\
\hline
\end{tabular}

$\mathrm{n}=3$; Sd - standard deviation; EH - samples of Eryngii herba

Table 5. The values of hemolytic activity of Eryngii radix, Eryngium campestre (saponin units per g plant material, SU/g)

\begin{tabular}{ccccccc}
\hline \hline & ER1/02 & ER2/02 & ER3/02 & ER1/03 & ER2/03 & ER3/03 \\
\hline HI & 14.4 & 15.3 & 15.8 & 14.9 & 16.3 & 14.08 \\
\hline
\end{tabular}

$\mathrm{ER}$ - samples of Eryngii radix, $\mathrm{n}=3$. 
is (radix) (120 SU/g), (Ph. Jug. 5). Data of hemolytic activity of Eryngii radix are not available in the literature. Among information about the presence of triterpene saponins in Eryngium campestre and other Eryngium species, data of chemical structure of saponins could be found (Kartal et al. 2005; 2006). Romanian researchers investigated the chemical composition of indigenous Eryngium species in Romania (E. planum, E. campestre and E. maritimum) and found that triterpene saponins (determined by gravimetric method) were presented in the aerial part of the plants, ranging from 3.7-10.1\% (Suciu et al. 2006).

\section{Mineral content}

Determination of mineral content included determination of eight microelements $(\mathrm{Cd}, \mathrm{Co}, \mathrm{Cr}, \mathrm{Cu}, \mathrm{Fe}, \mathrm{Mn}, \mathrm{Pb}$ and $\mathrm{Zn}$ ) and two macroelements ( $\mathrm{Na}$ and $\mathrm{K}$ ). The results obtained for the samples of Eryngii herba and Eryngii radix are presented in Table 6. Obtained results differ a lot depending on the plant organ or the origin of the sample. In some cases the content of investigated minerals in Eryngii herba was relatively constant such as that of Zn (15.14$\left.20.39 \mathrm{mg} \mathrm{kg}^{-1}\right), \mathrm{Cr}(0.7-1.57 \mathrm{mg} / \mathrm{kg})$ or $\mathrm{Cu}(8.17-11.17 \mathrm{mg}$ $\mathrm{kg}^{-1}$ ) while for the other minerals higher variability occurs (Fe from 69.93-196.77 $\mathrm{mg} \mathrm{kg}^{-1}$; Mn 31.46-47.68 $\mathrm{mg} \mathrm{kg}^{-1}$ ). The content of toxic elements was very low, from 0.17 $1.33 \mathrm{mg} \mathrm{kg}^{-1}$ and from $0.05-0.12 \mathrm{mg} \mathrm{kg}^{-1}$ for $\mathrm{Pb}$ and $\mathrm{Cd}$, respectively. The content of $\mathrm{K}$ in Eryngii herba was very high, from $1765.10-2538.08 \mathrm{mg} \mathrm{kg}^{-1}$ while the content of $\mathrm{Na}$ ranged from $43.65-94.7 \mathrm{mg} \mathrm{kg}^{-1}$.

Similar results were obtained for the content of minerals in Eryngii radix (Table 6). The content of Mn was almost the same as it was found in herba, from 25.19-41.19 $\mathrm{mg} \mathrm{kg}{ }^{-1}$, the content of $\mathrm{Zn}$ ranged from 15.55-25.29 $\mathrm{mg}$ $\mathrm{kg}^{-1}$, and for $\mathrm{Cu}$ from $9.16-12.45 \mathrm{mg} \mathrm{kg}^{-1}$. Great variabili- ty in the content of Fe was occurred again and significantly larger amounts were found in Eryngii radix ranging from 198.9-325.7 $\mathrm{mg} \mathrm{kg}^{-1}$. The content of $\mathrm{Na}$ in Eryngii radix was higher than in Eryngii herba, ranging from 170.2$590.9 \mathrm{mg} \mathrm{kg}^{-1}$, while the content of K in Eryngii radix was also very high, from $743.7-961.8 \mathrm{mg} \mathrm{kg}^{-1}$ but significantly lower than in Eryngii herba. The content of toxic elements was very low, from $0.10-1.76 \mathrm{mg} \mathrm{kg}^{-1}$ and from $0.04-0.16$ $\mathrm{mg} \mathrm{kg}^{-1}$ for $\mathrm{Pb}$ and $\mathrm{Cd}$, respectively.

Generally, Eryngii herba accumulates larger amounts of $\mathrm{K}$ while Eryngii radix accumulates larger amounts of $\mathrm{Na}$ and Fe. Comparing with the literature data, the leaves of E. billardieri contain higher amount of $\mathrm{N}, \mathrm{K}, \mathrm{Ca}$ and $\mathrm{Mg}$ and lower amount of $\mathrm{P}, \mathrm{S}$ and $\mathrm{Na}$ than some common vegetables, while the content of $\mathrm{Fe}, \mathrm{Mn}, \mathrm{Zn}$ and $\mathrm{Cu}$ were at the same level (Turan et al. 2003). In leaves of E. foetidisima, $24.26 \mathrm{mg} \mathrm{g}^{-1} \mathrm{Fe}$ and $11.26 \mathrm{mg} \mathrm{g}^{-1} \mathrm{~K}$ were found (Borah et al. 2009).

\section{Radical scavenging and antioxidant activity}

\section{DPPH free radical scavenging activity}

Free radical scavenging activity of Eryngium extracts was determined by comparing the activity with that of referent substances (quercetin and BHA), which possess known antioxidant potential. The values obtained in DPPH assay for plant extracts are shown together with that of reference substances (Table 7). The highest scavenging effect was obtained with quercetin $\left(\mathrm{IC}_{50}=0.06 \mathrm{mg} \mathrm{ml}^{-1}\right)$ and the lowest one with the root extract of $E$. campestre $\left(\mathrm{IC}_{50}=1.14\right.$ $\left.\mathrm{mg} \mathrm{ml}^{-1}\right)$. The results suggest that $E$. campestre extracts act as non-specific donators for hydrogen atoms or electrons in the DPPH-assay. When compared to the reference substances, the Eryngium extracts were found to be less efficient. Nevertheless, the existing scavenging effects of the

Table 6. The content of minerals in Eryngii herba and Eryngii radix after mineralization in micro-wave digestion system (MW) $(w / \mathrm{mg} / \mathrm{kg})$

\begin{tabular}{lcccccccccc}
\hline \hline Sample & $\mathrm{Cd}$ & $\mathrm{Co}$ & $\mathrm{Cr}$ & $\mathrm{Cu}$ & $\mathrm{Fe}$ & $\mathrm{K}$ & $\mathrm{Mn}$ & $\mathrm{Na}$ & $\mathrm{Pb}$ & $\mathrm{Zn}$ \\
\hline \multicolumn{1}{c}{ Eryngii herba } & & & & & & & & & \\
EH1/02 & 0.11 & 0.08 & 0.70 & 8.17 & 69.9 & 1963 & 33.78 & 43.66 & 0.17 & 17.19 \\
EH2/02 & 0.14 & 0.10 & 1.57 & 9.90 & 119.7 & 2167 & 47.68 & 81.50 & 0.75 & 19.17 \\
EH3/02 & 0.11 & 0.08 & 1.58 & 8.26 & 114.5 & 2228 & 44.67 & 56.74 & 0.28 & 20.40 \\
EH1/03 & 0.067 & 0.09 & 1.55 & 11.17 & 148.6 & 1774 & 32.51 & 46.15 & 0.18 & 15.99 \\
EH2/03 & 0.06 & 0.13 & 1.36 & 10.39 & 196.8 & 1765 & 31.46 & 62.87 & 0.97 & 15.93 \\
EH3/03 & 0.10 & 0.10 & 1.23 & 10.74 & 162.5 & 1797 & 32.86 & 94.70 & 1.33 & 17.47 \\
Eryngii radix & & & & & & & & & \\
ER1/02 & 0.16 & 0.50 & 3.19 & 12.45 & 213.7 & 934 & 26.11 & 590.91 & 0.14 & 25.29 \\
ER2/02 & 0.12 & 0.44 & 4.33 & 11.29 & 209.7 & 849 & 25.19 & 551.85 & 0.36 & 22.63 \\
ER3/02 & 0.10 & 0.49 & 3.82 & 10.64 & 325.7 & 744 & 26.02 & 492.99 & 0.10 & 20.95 \\
ER1/03 & 0.04 & 0.24 & 2.53 & 9.16 & 198.9 & 932 & 41.41 & 170.70 & 0.46 & 16.57 \\
ER2/03 & 0.09 & 0.18 & 2.45 & 9.52 & 208.7 & 962 & 41.18 & 172.38 & 1.76 & 16.68 \\
ER3/03 & 0.06 & 0.19 & 2.03 & 10.43 & 183.3 & 910 & 41.19 & 218.67 & 0.62 & 15.56 \\
\hline
\end{tabular}


examined extracts probably could be attributed to the presence of flavonoids, but also could be resulted of the activity of other secondary biomoleculs present in the extracts.

Compared to literature data, different Eryngium species manifest different radical scavenging activity. Thus, the methanol extracts of leaves and inflorescence of Eryngium caucasicum at flowering stage show remarkable activity with $\mathrm{IC}_{50}=0.15 \pm 0.01 \mathrm{mg} \mathrm{ml}^{-1}$ for leaves and $0.39 \pm$ $0.02 \mathrm{mg} \mathrm{ml}^{-1}$ for inflorescence (Ebrahimzadeh et al. 2009; Nabavi et al. 2009). Radical scavenging activity of E. maritimum methanol extract was investigated, as well, revealing $\mathrm{IC}_{50}=0.28 \mathrm{mg} \mathrm{ml}^{-1}$ in the ABTS assay (Meot-Duros et al. 2008).

Table 7. Free radical scavenging activity of the extracts of Eryngium campestre in DPPH assay and inhibition of $\mathrm{OH}^{-}$radical production (\%)

\begin{tabular}{ccc}
\hline \hline Sample & $\begin{array}{c}\text { DPPH assay } \\
\left(\mathrm{IC}_{50}, \mathrm{mg} / \mathrm{ml}\right)\end{array}$ & $\begin{array}{c}\mathrm{OH}^{-} \\
(\% \text { of inhibition })\end{array}$ \\
\hline Eryngii radix & 0.72 & 45.00 \\
Eryngii herba & 1.14 & 50.11 \\
Quercetin & 0.06 & 42.05 \\
BHA & 0.15 & 52.09 \\
\hline
\end{tabular}

\section{Hydroxyl radical scavenging activity}

The effect of Eryngium extracts on the inhibition of hydroxyl radical production $\left(\mathrm{IOH}^{-}\right)$was assessed by the iron (II)-dependent deoxyribose damage assay. It is well known that the Fenton reaction generates hydroxyl radicals $\left(\mathrm{OH}^{-}\right)$, which degrade deoxyribose, using $\mathrm{Fe}^{2+}$ salts as an important catalytic component (Haliwell and Gutteridge, 1981). Oxygen radicals may attack sugar, which leads to sugar fragmentation. Addition of transition metal ions such as iron at low concentrations to deoxyribose, causes degradation of sugar into malondialdehyde and other related compounds which form a chromogen with thiobarbituric acid (TBA). Table 7 presents the results of the effects of examined Eryngium extracts as well as that of reference substances on $\mathrm{OH}^{-}$radical production. They show that both extracts of Eryngium campestre and reference substances inhibited the production of $\mathrm{OH}^{-}$radicals. The strongest inhibitory activity was exhibited by BHA (52\%). Both extracts of Eryngium campestre exhibited significant inhibitory effect, $45 \%$ and $50 \%$, respectively, higher than the percentage of inhibition obtained by quercetin (42\%). Previously, it has been shown that quercetin and its glycosides exert inhibitory activity against lipid peroxidation (Cook and Samman, 1996; Dangles, 2000).

\section{Antioxidant activity}

The antioxidant activity of Eryngium campestre extracts was weak in $\beta$-carotene/linoleic acid system. From the results mentioned above, it was shown that Eryngium campestre extracts exhibited strong free radical scavenging activity against $\mathrm{DPPH}$ and $\mathrm{OH}^{-}$radicals, comparable to the activity of quercetin and BHA. In the $\beta$-carotene/linoleic acid system Eryngii extracts have shown modest antioxidant effects, which was comparable with the activity of quercetin for the period of the first 60 minutes (Table 8). According to the literature data, antioxidant activity of Eryngium species is an interesting topic for the scinence. It was found that antioxidant index of leaf extract of E. foetidum determined by measuring the coupled oxidation of carotene and linoleic acid had a value of 5.65 \pm 0.46 . The antioxidant index is the ratio of bleaching rate of control (system with no added test compounds) to the bleaching rate when a test compounds was added into the system (Chanwitheesuk et al. 2005). It was reported that vitamins $\mathrm{C}$ and E, carotenes, xanthophylls, tannins and total phenolics may be responsible for the activity, as they were present in leaves of E. foetidum (11.4; $0.0069 ; 1.92 ; 1.60 ; 17.7$ and $98.4(\mathrm{mg} \%)$, respectively). Accounting that the bleaching rate of $\beta$-carotene was determined by the differences in the spectral absorbance reading between the initial and last reading of bleaching that remained essentially linear, divided by time, antioxidant index was estimated for the investigated samples of Eyngium campestre. It was obtained that antioxidant index of Eryngii herba had a value of 0.54 while for Eryngii radix it was 0.69 . Both values were significantly under the antioxidant activity of $E$. foetidisima.

Table 8. Effect of ethanol extracts of Eryngium campestre in comparison to BHA and quercetin on the oxidation of $\beta$-carotenebleaching assay

\begin{tabular}{|c|c|c|c|c|c|c|c|c|c|}
\hline \multirow[t]{2}{*}{ Sample } & \multicolumn{9}{|c|}{$\begin{array}{c}\mathrm{A}_{470}(\% \text { of initial value }) \\
\text { Time (min) }\end{array}$} \\
\hline & 0 & 15 & 30 & 45 & 60 & 75 & 90 & 105 & 120 \\
\hline Eryngii radix & 100 & 80 & 60 & 52 & 42 & 40 & 38 & 37 & 36 \\
\hline Eryngii herba & 100 & 81 & 63 & 54 & 46 & 43 & 41 & 40 & 39 \\
\hline Quercetin & 100 & 89 & 82 & 62 & 46 & 34 & 26 & 20 & 16 \\
\hline BHA & 100 & 81 & 70 & 63 & 57 & 51 & 48 & 45 & 42 \\
\hline Control & 100 & 61 & 57 & 47 & 40 & 38 & 36 & 32 & 30 \\
\hline
\end{tabular}

Макед. фарм. билт., 55 (1, 2) 22 - 32 (2009) 


\section{Inhibition of lipid peroxidation (LP)}

Antioxidant activity of ethanol extracts of the aerial part and root of E. campestre was examined over the inhibition of spontaneous lipid peroxidation in rat liver homogenate as well, measuring the content of formed MDA by TBA assay (TBARS). The results given in Table 9 showed that the content of formed MDA was lower when the extract of root or aerial part were added into the system (3.67 \pm 0.04 and $4.05 \pm 0.07 \mathrm{nmol} \mathrm{ml}^{-1}$, respectively), but still the levels of MDA were significantly higher than those obtained when quercetin was used as an antioxidant (3.12 \pm $0.04 \mathrm{nmol} \mathrm{ml}^{-1}$ ).

Table 9. The content of MDA (nmol mg-1) and the inhibition of lipid peroxidation (\%) in rat liver homogenate by ethanol extracts of aerial part and root of E. campestre

\begin{tabular}{lcc}
\hline \hline Sample & $\begin{array}{c}\text { TBARS - homogenate } \\
(\text { nmol MDA } \\
\text { mg protein }\end{array}$ & $\begin{array}{c}\text { Inhibition } \\
\text { of LP } \\
(\%)\end{array}$ \\
\hline $\begin{array}{l}\text { Control } \\
\text { (ethanol) }\end{array}$ & $4.60 \pm 0.02$ & 0.0 \\
Eryngii radix & $3.67 \pm 0.04$ & 20.0 \\
Eryngii herba & $4.05 \pm 0.07$ & 12.2 \\
Quercetin & $3.12 \pm 0.04$ & 36.9 \\
\hline
\end{tabular}

The range of inhibition of lipid peroxidation in the rat liver homogenate was $20 \%$ and $12 \%$ for the extract of root and aerial part of E. campestre, respectively. Obtained values were lower than that of quercetin (36.9\%). Compared to the recently published data on the activity of some other wild plants such as Calamintha nepeta, Calamintha gradiflora and Micromeria cristata, higher inhibition activity of ethanol extracts on lipid peroxidation in the same biological system was exhibited $(20.35 \%, 25.6 \%$ and $29.6 \%$ of inhibition, respectively) (Kadifkova Panovska 2004). Besides evident free radical scavenging activity against DPPH and hydroxyl $\left(\mathrm{OH}^{\cdot}\right)$ radical, antioxidant activity of Eryngium campestre in both non-biological ( $\beta$-carotene/linoleic acid) and biological (rat liver homogenate) system manifested a low capacity.

\section{Conclusion}

Analysis of the chemical composition of the aerial part and root of Eryngium campestre from Kosovo showed that the content of total ash, ash insoluble in hydrochloric acid, loss on drying and the content of water extract were relatively constant regardles the differences in the characteristics of the locations and year of collection. Samples of Eryngii herba gave lower percentage of water extract (18.3$24.5 \%$ ) in comparison to the samples of Eryngii radix (29.6-36.6\%). The analysis of mineral content ( $\mathrm{Zn}, \mathrm{Fe}, \mathrm{Cu}$,
$\mathrm{Mn}, \mathrm{Ni}, \mathrm{K}, \mathrm{Co}, \mathrm{Pb}, \mathrm{Cd}$ and $\mathrm{Cr}$ ) showed that different part of $E$. campestre accumulate different amount of investigated minerals. Evaluation of radical scavenging and antioxidant activity showed that higher radical-scavenging activity against $\mathrm{DPPH}^{-}$radical has been presented by the ethanol extract of root of $E$. campestre $\left(\mathrm{IC}_{50}=0.72 \mathrm{mg} \mathrm{ml}^{-1}\right)$ compared to the aerial part of the plant $\left(\mathrm{IC}_{50}=1.14 \mathrm{mg} \mathrm{ml}^{-1}\right)$. Furthermore, the inhibition capacity on the production of hydroxyl radical in deoxyribose system was found to be strong $(50 \%$ and $45 \%$ for aerial part and root ethanol extract, respectively). However, both ethanol extracts of $E$. campestre from aerial part and root, exhibited low antioxidant activity in $\beta$-carotene/linoleic acid system as well as low capacity for inhibition of spontaneous lipid peroxidation in rat liver homogenate.

\section{Acknowledgment}

Authors are grateful to Assistant professor Biljana Miova from Institute of Biology at the Faculty of Natural Sciences and Mathematics for preparation and supplying with rat liver homogenate.

\section{References}

Alkofahi, A., Salla, A.J., Disi A.M. 1997. Effect of Eryngium creticum on the haemolytic activities of snake and scorpion venoms, Phytother. Res. 11(7), 540-542.

Al-Khail, S. 1994. Phytochemistry of Eryngium creticum, Mexandtia J. Pharm. Sci. 8, 73-75.

Assenov, Iv., Gevrenova, R. 1991. D-Mannitol from Eryngium campestre L. Farmatsia-Sofia 41(5-6), 26-28.

Borah, S., Baruah, A.M., Das, A.K., Borah, J. 2009. Determination of mineral content in commonly consumed leafy vegetables, Food and Anal. Methods 2, 226-230.

Bradford, M. M. 1976. A rapid and sensitive method for quantitation of microgram quantities of protein utilizing the principle of protein-dye-binding, Anal. Biochem. 72, 248254.

Capetanos, C., Saraglou, V., Marin, P., Simic, A., Skaltsa, H. 2007. Essential oil analysis of two endemic Eryngium species from Serbia, J. Serb. Chem. Soc. 72(10), 961-965.

Chanwitheesuk, A., Teerawutgulrag, A., Rakariyatham, N. 2005. Screening of antioxidant activity and antioxidant compounds of some edible plants of Thailand, Food Chemistry 92, 491497.

Cook, N.C., Samman, S. 1996. Flavonoids-chemistry, metabolism, cardioprotective effects, and dietary sources, Nutritional Biochemistry 7, 66-76.

Dangles, O. 2000. Inhibition of lipid peroxidation by quercetin and quercetin derivatives: antioxidant and prooxidant effects, J. Chem. Soc. Perkin Trans. 2, 1215-1222. DOI: 10.1039/ A910183G

Garcia, M.D., Saenz, M.T., Gomez, M.A., Fernandez, M.A. 1999. Topical anti-inflammatory activity of phytosterols isolated from Eryngium foetidum on cronic and acute inflammation models, Phytother. Res. 13, 78-80.

Ebrahimzadeh, A.M., Nabavi, S.F., Nabavi, S.M. 2009. Antioxidant activity of leaves and inflorescence of Eryngium caucasicum Tratv at flowering stage, Pharmacognosy Res. 
$1(6), 435-439$.

El-Gamal, M.H.A., Ei-Bay, F.K., Ei-Tawill, B.A.H., Gadalla, K.Z. 1978. Constituens of local plants. XXI. The coumarins of Ficus salicifolia L. fruits, Eryngium creticum Lam. and Pityrathus tortuosus Deaf. Erypt. J. Chem. 18(4), 767-72.

Erdelmeier C.A.J., Sticher, O. 1986. A cyclohexanone and a cyclohexadienone glycoside from Eryngium campestre, Phytochemistry 741-743.

Erdelmeier, C. A. J., Sticher, O. 1985. Coumarins derivatives from Eryngium campestre, Planta Medica 5, 407-409.

Halliwell, B., Gutteridge, J.M.C. 1981. Formation of a thiobarbituric acid-reactive substance from deoxyribose in the presence of iron salts: The role of superoxide and hydroxyl radicals, FEBS Letters 128, 347-352.

Hiller, K., Keipert, M., Pfeifer, S. 1972. Constituens of some Saniculoideae. 16. Isolation of esters of barringtogenol C from Eryngium planum, Pharmazie 27(5), 341-343.

Hiller, K., Nguyen, K.Q.C., Franke, P. 1978. Isolation of 3-OD-glucopyranosyloleanolic acid 28-O-xylopiranoside from Eryngium bromeliifolium Delar. Part 29. Data on the constitution for several Saniculoideae, Pharmazie 33(1), 78-80.

Hiller, K., Nguyen, K.Q.C., Franke, P., Hintsche, R. 1976. Contents of several Saniculoidae, Part 26. Isolation of betuilinic acid 3-O- $\beta$-D-glucoside, a saponin from Eryngium bromeliifolium Delar., Pharmazie 31(13), 891-893.

Hiller, K., Nguyen, Van Thi, Lehman, G., Grundemann. E. 1974. Saniculoidae components. 21. Betulinic acid, a sapogenin in Eryngium bromelifolium. Pharmazie 29(2), 148-149.

Hiller, K., Pohl, B., Franke, P. 1981. Flavonoid spectrum of Eryngium maritinum L. part 35. Components of Saniculoidae, Pharmazie 36(6) 451-452.

Hiller, K., Von Mach, B., Franke, P. 1976. On the saponins of Eryngium maritinum L. Part 25. Toward information on components of some Saniculoide, Pharmazie 31(1), 53-56.

Hohmann, J., Pall, Z., Guenther, G., Mathe I. 1997. Flavonolacyl glycosides of the aerial parts of Eryngium campestre, Planta medica 63(1), 96-99.

Ingram, M. 2006. Species account: Eryngium campestre, Botanical Societ of the British Isles. www.bsbi.uk

Кадифкова Пановска Т. 2004. Утврдување на механизмите на антиоксидативната активност на некои природни производиинивнатахепатопротективна (хепатотоксична) активност во биолошки модел системи, докторска дисертација, Фармацевтски факултет, УКИМ, Скопје.

Kartal, M., Mitaine-Offer, A.C., Abi-Asker, M., Miyamoto, T., Calis, I., Wagner, H., Lacaille-Dubois, M.A. 2005. Two new triterpene saponins from Eryngium campestre, Chem. Pharm. Bull. (Tokyo) 53(10), 1318-1320.

Kartal, M., Mitaine-Offer, A.C., Paululat, T., Abi-Asker, M., Wagner, H., Mirjolet, J.F., Guilbaud, N., Lacaille-Dubois, M.A. 2006. Triterpene saponins from Eryngium campestre, J. Nat. Prod. 69 (7), 1105-1108.

Kartnig, T., Wolf, J. 1993. Flavonoids from the aboveground parts of Eryngium campestre, Planta medica 59(3), 285.

Kupeli, E., Kartal, M., Aslan, S., Yesilada, E. 2006. Comparative evaluation of the anti-inflammatory and antinociceptive activity of Turkish Eryngium species, J. Ethnopharmacol. 107(1), 32-37.

Leclercq, P.A., Dung, N.X., Lo, V.N., Toanh, N.V. 1992. Compositrion of the essential oil of Eryngium foetidum L. from Vietnam, J. Essent. Oil Res. 4, 423-424.

Lisciani, R., Fattorusso, E., Surano, V., Cozzolino, S., Giannattasio, M., Sorrentino, L. 1984. Anti-inflammatory activity of
Eryngium maritimum L. rhizome extracts in intact rats, J. Ethnopharmacol. 12(3), 263-270.

Moet-Duros, L., Le Floch, G., Magne, C. 2008. Radical scavenging, antioxidant and antimicrobial activities of halophytic species, J. Ethnopharmacol. 116(2), 258-262.

Nabavi, S.M., Nabavi, S.F., Ebrahimzadeh, M.A., Banham, E. 2009. In vitro antioxidant activity of Pyrus boissieriana, Diospyros lotus, Eryngium caucasicum and Froriepia subpinnata, J. Rafsanjan Univ. Med. Sci. Healt Services 8(2), 137-148.

Nebija, F., Kulevanova, S., Stefova, M. 2006. Identificatiom and determination of flavonoids in Eryngii herba (Eryngium capestre L., Apiaceae), Maced. Pharm. Bull. 52(1,2), 73-80.

Ohkawa, H., Ohishi, N., Jagi, K. 1979. Assay for lipid peroxides in animal tissues by thiobarbituric acid reaction, Anal. Biochem. 95, 351-358.

Organic Herb Gardening, http://www.gardenzone.info/herbs/ fielderyngo.php?lang=latin

Pala-Paul, J., Perez-Alonso, M.J., Velasco-Negueruela, A., Varade, J., Vila, A.M., Sanz, J., Brophy, J.J. 2005. Analysis of the essential oil composition from different parts of Eryngium glaciale Boiss. from Spain, J. Chromatogr. A 1094(1,2), 179-182.

Petkov, V. 1982. Sovremena fitoterapija, Medicina i fiskultura, Sofija, 297-298.

Ph. JUG. IV, Pharmacopoeia Jugoslavica, 1984. $4^{\text {th }}$ ed., National Institute for Health Protection: Belgrade.

Ph. JUG. V, Pharmacopoeia Jugoslavica 2000. $5^{\text {th }}$ ed., National Institute for Health Protection: Belgrade, 123-126.

Ph. Eur. 4 - European Pharmacvopoeia 2002. $4^{\text {th }}$ edition, Council of Europe, Strasbourg.

Pinar, M., Galan, M.P. 1985. Coumarines from Eryngium ilicifolium, J. Nat. Prod. 48(5), 853-854.

Pino, J.A., Rosado, A., Fuentes, V. 1997a. Chemical composition of the seed oil of Eryngium foetidum L. from Cuba, J. Essent. Oil Res. 9, 123-124.

Pino, J.A., Rosado, A., Fuentes, V. 1997b. Composition of the leaf oil of Eryngium foetidum L. from Cuba, J. Essent. Oil Res. 9, 467-468.

Saenz, M.T., Fernandez, M.A., Garcia, M.D. 1998. Antiinflammatory and analgesic properties from leaves of Eryngium foetidum L. (Apiaceae), Phytother. Res. 11, 380-383.

Simon, O.R., Singh, N. 1986. Demonstration of anticonvulsant properties af an aqueous extract of spirt weed (Eryngium foetidum L.), West. Indian Med. J. 35, 121-125.

Stecka-Paszkiewez, L. 1983. Kaempherol 3,7-di-rhamnoside from Eryngium planum L., Z. Chem. 23(8), 294-295.

Suciu, S., Bodoki, E., Vlase, L. 2006. Comparative phytochemical study on Eryngium sp. from Romania, $4^{\text {th }}$ Conference of Medicinal and Aromatic Plants of South-East European Countries, Book of abstracts, 64-65.

Tagashira, M., Ohtake, Y. 1998. A new antioxidative 1,3benzodioxole from Melissa officinalis, Planta Medica 64, $555-558$.

Turan, M., Kordali, S., Zengin, H., Dursun, A., Sezen, Y. 2003. Macro and micro mineral content of some wild edible leaves consumed in Eastern Anatolia, Acta Agric. Scand., Sect. B, Soil and Plant Sci. 53, 129-137.

Wanasundara, U., Amarowicz, R., Shahidi, F. 1994. Isolation and identification of an antioxidative component in canola meal, J. Agric. Food Chem. 42, 1285-1290.

Wong, K.C., Feng, M.C., Sam, T.W., Tan, G.L. 1994. Composition of the leaf and root oils of Eryngium foetidum L., J. Essent. Oil Res. 6, 369-374. 
Zarnack, J., Hiller, K., Otto, A. 1977. The components of several Saniculoideae. XXXVIII. Isolation of kaemferol 3,7-di- rhamnozide from Eryngium planum L., Z. Chem. 17(12), 445-455.

Резиме

\title{
Хемиска карактеризација и антиоксидативна активност на Eryngium campestre L., Apiaceae од Косово
}

\author{
Флурим Небија ${ }^{1}$, Ѓше Стефков², Марија Карапанџова², Трајче Стафилов \\ Татјана Кадифкова Пановска², Светлана Кулеванова ${ }^{2 *}$ \\ ${ }^{1}$ Медицински факултет - Отсек за фармација, Универзитет во Приштина, Приштина, Косово, \\ ${ }^{2}$ Фармачевтски факултет, УКИМ, Скопје, Република Македонија, \\ ${ }^{3}$ Институт за хемија, ПМФ УКИМ, Скопје, Република Македонија
}

Клучни зборови: Eryngium campestre, флавоноиди, минерали, DPPH тест, антиоксидативна активност, $\beta$-каротен-избелувачки тест, ТВА тест.

\begin{abstract}
Оваа студија се однесува на дефинирање на хемиски состав и утврдување на антиоксидативна активност in vitro на екстракти подготвени од надземниот дел и од коренот на Eryngium campestre L. (Арiaceae) од Косово. Анализата на хемискиот состав вклучува определување на вкупен пепел, пепел нерастворлив во хлороводородна киселина, губиток со сушење и содржина на воден екстракт, како и определување на содржина на вкупни флавоноиди во надземниот дел и хемолитична активност на коренот. Составот на минералите ( $\mathrm{Zn}, \mathrm{Fe}, \mathrm{Cu}, \mathrm{Mn}, \mathrm{Ni}, \mathrm{K}, \mathrm{Co}, \mathrm{Pb}, \mathrm{Cd}$ и $\mathrm{Cr}$ ) во надземниот дел и во коренот се определени со користење на атомска апсорпциона спектроскопија (AAS и ETAAS). Утврдено е дека различните делови од E. campestre акумулираат различни количества од испитуваните минерали. Антиоксидативната активност е испитувана со четири методи: DPPH тест, инхибиција на продукција на хидроксил радикал, $\beta$-каротен-избелувачки тест и инхибиција на липидна пероксидација (TBA тест). Bo DPPH системот етанолните екстракти од коренот покажуваат подобра радикал-фаќачка активност $\left(\mathrm{IC}_{50}=0.72 \mathrm{mg} \mathrm{ml}^{-1}\right)$ во споредба со соодветните екстракти од надземниот дел $\left(\mathrm{IC}_{50}=1.14 \mathrm{mg} \mathrm{ml}^{-1}\right)$. Од друга страна, етанолниот екстракт од надземниот дел покажува поголем инхибирачки капацитет врз продукцијата на хидроксил радикалот во системот од дезоксирибоза во споредба со екстрактот од коренот (50\% и 45\%, соодветно). Двата етанолни екстракта од $E$. campestre покажуваат ниска антиоксидативна активност во $\beta$-каротен-избелувачки тест, како и низок капацитет за инхибирање на спонтана липидна пероксидација во хомогенат од црн дроб од стаорец.
\end{abstract}




\title{
Seasonal variation of flavonoids in Teucrium polium $\mathrm{L}$. (Lamiaceae)
}

\author{
Gjoshe Stefkov $^{1 *}$, Marija Karapandzova ${ }^{1}$, Marina Stefova², \\ Svetlana Kulevanova ${ }^{1}$
}

\author{
${ }^{1}$ Institute of Pharmacognosy, Faculty of Pharmacy, University Ss Cyril and Methodius, Skopje, Republic of Macedonia \\ ${ }^{2}$ Institute of Chemistry, Faculty of Natural Sciences and Mathematics, University Ss Cyril and Methodius, Skopje, Republic \\ of Macedonia
}

Received: January 2009, Accepted: February 2009

\begin{abstract}
The aim of the present study was identification of flavone aglycones and determination of the content of each and the content of total flavonoids as well as investigation of the eventual seasonal variations of flavonoids in Teucrium polium L. (Lamiaceae). The plant samples were collected at six different locations in Republic of Macedonia, during summer in 1999, 2000 and 2003. For determination of seasonal variations, the samples were collected in v. Koleshino, in 2004, each month during the whole season. Six flavone aglycones (luteolin, apigenin, diosmetin, cirsiliol, cirsimaritin and cirsilineol) were identified in the hydrolyzed extracts of the over ground part of Teucrium polium by HPLC method. The most abundant flavone was luteolin, followed by apigenin and cirsimaritin. Great seasonal variations were found in the content of each and in the content of total amount of flavonoids. The most abundant flavone during the whole season was luteolin with the highest content in May. The content of total flavonids was the highest in the period from May to July, which could be recommended as the most convenience period in the season for collecting of the plant material from Teucrium polium.
\end{abstract}

Key words: Teucrium polium, flavonoids, HPLC analysis, seasonal variation

\section{Introduction}

Teucrium polium L. (Lamiaceae) is a sub-shrub plant native to the Mediterranean region and the Middle East. In Republic of Macedonia it is widely distributed and traditionally used by native inhabitants, as herbal hypoglycemic tea. The decoctum of T. polium is used as an appetizer especially in children and also as a spice. Some biological and therapeutic effects have been reported for the plant such as antioxidant (Esmaeili et al., 2009; Ardestani et al., 2008), antiinflammatory (Tariq et al., 1989; Capasso et al., 1983), antinociceptive (Baluchnejadmojarad et al., 2005; Abdollahi et al., 2003), antipyretic (Aggelis et al., 1998; Autore et al., 1984), anti-microbial (Autore et al., 1984), hypolipidemic (Rasekh et al., 2001), hepatopro- tective (Panovska et al., 2007), cytotoxic and apoptotic effects (Rajabalian et al., 2008). The plant poses complex chemical composition with presence of new clerodane type diterpenes (Malakov and Papanov, 1983; Marquez and Valverde, 1979), essential oil with dominating sesquiterpene alcohols and pinenes (Cozzani et al., 2005; Moghtader, 2009; Kabouche et al., 2007), phenylethanoid glycosides such as verbascoside and poliumoside (Oganesyan et al.,1991), flavone glycosides with highly methylated aglycons (Verykokidou-Vitsaropoulou and Vajias, 1986; Rizk et al., 1986; Kawashty et al., 1999; Harborne et al., 1986; Sharififar et al., 2009), etc.

Flavonoids are representing the most important group of active components of Teucrium species, and many of the activities of these plants are attributed to the flavonoid

* gstefkov@yahoo.com 
class of secondary metabolites. It is also well known that the composition and the content of the flavonoids in plant material could be variable depending of the season, location and environmental condition of plant growth as well as the influence of other different factors (Liu et al., 1994; De Castro, et al., 2006; Bagdonaite et al., 2009). Seasonal variations of flavonoids were also studied in different plant species (Luengas-Caicedo et al., 2007; Akabori, 1978; Ioku et al., 2005; Xu et al., 2009).

Until now, there is no published data about the seasonal variation in the composition and the content of the flavonoids in Teucrium polium. Taking into account all of these, the aim of the present study were identification, quantification and determination of the seasonal variations of the flavonoids in Teucrium polium from Macedonian origin.

\section{Material and methods}

\section{Plant material}

The over-ground parts of the plant of 6 different populations of T. polium were collected during the summer of 1999, 2000, 2003 and 2004 (Table 1). The plant material was air dried, packed in paper bags and kept in a dark and cool place until analysis. Plant identity was verified and voucher specimens were deposited at the Institute of Pharmacognosy, Faculty of Pharmacy, Skopje, R. Macedonia.

\section{Reagents and authentic samples}

Reagents of HPLC purity were purchased from Sigma Chemical Co. (Germany). Authentic substances apigenin, luteolin, chryseriol, diosmetin, acacetin, genkwanin, naringenin and eryiodictiol were the products of Extrasynthese (France). Cirsimaritin, cirsilineol, and 5,4'$\mathrm{OH}$ and $6,7,8,3^{\prime}-\mathrm{OCH}_{3}$ flavones were kindly donated by Dr. B. Voirin from the Laboratoire de Phytochimie, U. E. R. des Sciences de la Nature, Université Claude Bernard Lyon, France.

\section{Preparation of hydrolyzed extracts}

Grounded plant material (1 g) was extracted in an Erlenmeyer flask with reflux in a water bath with mixture of $25 \mathrm{ml}$ acetone, $1 \mathrm{ml}$ of concentrated $\mathrm{HCl}$ and $0.5 \mathrm{ml}$ of $1 \%$ solution of urotropine. The extraction was performed twice, first for $40 \mathrm{~min}$ at $60{ }^{\circ} \mathrm{C}$ and then for 20 minutes more on the same temperature. The extracts were cooled, filtered and transferred to a $50 \mathrm{ml}$ volumetric flask and filled up with acetone. $10 \mathrm{ml}$ were transferred to a separating funnel. Water $(25 \mathrm{ml})$ was added and extraction with ethyl acetate was repeated 3 times with $10 \mathrm{ml}$ portion. The ethyl acetate fractions were collected, washed three times with $25 \mathrm{ml}$ of water, then dried with anhydrous $\mathrm{Na}_{2} \mathrm{SO}_{4}$, filtered, and evaporated to dryness under low pressure. The residue was dissolved in $1 \mathrm{ml}$ methanol and the solution was used for analyses of flavonoid aglycones by HPLC.

\section{HPLC analysis}

Flavonoid aglycones in the hydrolyzed extracts were analyzed by the HPLC method, using a Varian HPLC system equipped with a ternary pump Model 9012 and UV diode-array detector Model 9065. A reverse phase column C18 (250 x $4.6 \mathrm{~mm}, 5 \mu \mathrm{m}$ particles) was used. The column was stabilized in thermostat on $35{ }^{\circ} \mathrm{C}$ with heater of column (CH-30) and temperature controller (TC-45). The mobile phase consisted of $\mathrm{H}_{2} \mathrm{O}$ with $\mathrm{pH}$ adjusted to 3 with $\mathrm{H}_{3} \mathrm{PO}_{4}(\mathrm{~A})$ and $\mathrm{CH}_{3} \mathrm{CN}$ (B). The elution program for extracts screening was the following: $0-5 \min 70 \% \mathrm{~A} ; 10$ $20 \min 65 \% \mathrm{~A} ; 25-30 \mathrm{~min} 55 \% \mathrm{~A} ; 40-48 \mathrm{~min} 35 \% \mathrm{~A}$. The flow rate was $1 \mathrm{ml} \mathrm{min}^{-1}$, the temperature was set to $35^{\circ} \mathrm{C}$ and the injection volume was $20 \mu \mathrm{l}$.

The elution was monitored in the whole UV range and the chromatograms for flavone screening were best seen at $348 \mathrm{~nm}$, which is in the region where flavones exhibit an absorption maximum. Identification was made according to the retention times and UV spectra of the components compared to those of authentic samples of flavonoids. Semi-quantification of flavones was performed on the basis of the peak areas of flavones in the HPLC chromatograms at $348 \mathrm{~nm}$.

Table 1. The locations of collection of samples of T. polium

\begin{tabular}{cllll}
\hline \hline Species & $\begin{array}{c}\text { Voucher } \\
\text { specimen }\end{array}$ & \multicolumn{1}{c}{ Location } & $\begin{array}{c}\text { Mount and year of } \\
\text { collection }\end{array}$ & $\begin{array}{c}\text { Collection for determination of season- } \\
\text { al variation }\end{array}$ \\
\hline Teucrium polium & $\mathrm{T}_{\mathrm{p}}$ & v. Koleshino & July - 2003 & $\begin{array}{c}\text { Each month, from January to December, } \\
\text { in 2004. }\end{array}$ \\
Teucrium polium & $\mathrm{T}_{7}$ & v. Janche & July - 1999 & \\
Teucrium polium & $\mathrm{T}_{9}$ & v. Rashtak & July - 2000 & \\
Teucrium polium & $\mathrm{T}_{11}$ & v. Gari & July - 2000 & \\
Teucrium polium & $\mathrm{T}_{12}$ & Alshar & July - 2000 & \\
Teucrium polium & $\mathrm{T}_{15}$ & Arkutino & July - 2000 & \\
\hline
\end{tabular}




\section{Results and discussion}

\section{HPLC analysis of flavonoids}

The identification of flavone aglycons in the extracts of $T$. polium, was done by comparing the retention times and UV spectral data of the extract components with those of authentic flavonoid substances. Two mixtures of authentic substances of flavonoids were used, labeled as $\mathrm{St}_{1}$ and $\mathrm{St}_{2}$. The composition of the mixtures and relating retention times of flavonoids are presented in Table 2. The HPLC chromatograms of both mixtures of standards are presented on Fig.1.

Six flavone aglycons, luteolin, apigenin, cirsiliol, diosmetin, cirsimaritin and cirsilineol (Table 3) were identified in the hydrolyzed extracts of T. polium. As the authentic samples for the component cirsiliol was not available, identification was made using previously published data by Stefova et al. (2007) and other literature data (Verykokidou-Vitsaropoulou and Vajias, 1986; Rizk et al., 1986).
Table 2. Retention times $\left(t_{\mathrm{R}}\right)$ of the components in two mixture of authenthic samples of flavonoids $\left(\mathrm{St}_{1}\right.$ and $\mathrm{St}_{2}$ )

\begin{tabular}{|c|c|c|}
\hline Mixture & Structure & $t_{\mathrm{R}} / \min$ \\
\hline \multicolumn{3}{|l|}{$\mathrm{St}_{1}$} \\
\hline Apigenin & $5,7,4^{\prime}-\mathrm{OH}$ flavone & 15,59 \\
\hline Diosmetin & 5,7,3'-OH, 4'-OCH3 flavone & 17,65 \\
\hline Cirsimaritin & 5,4'-OH 6,7-OCH3- flavone & 26,77 \\
\hline Cirsilineol & 5,4'-OH 6,7,3'-OCH3-flavone & 28,43 \\
\hline Genkwanin & 5, 4'-OH 7-OCH3 flavone & 32,98 \\
\hline \multicolumn{3}{|c|}{ s } \\
\hline Eryodictiol & $5,7,3^{\prime}, 4^{\prime}$-OH flavanone & 9,15 \\
\hline Luteolin & $5,7,3^{\prime}, 4^{\prime}-\mathrm{OH}$ flavone & 10,79 \\
\hline Naringenin & $5,7,4^{\prime}-\mathrm{OH}$ flavanone & 13,82 \\
\hline Apigenin & $5,7,4^{\prime}-\mathrm{OH}$ flavone & 15,73 \\
\hline Chryseriol & $5,7,4^{\prime}-\mathrm{OH}, 3$ ' $-\mathrm{OCH}_{3}$ flavone & 17,31 \\
\hline Diosmetin & $5,7,3^{\prime}-\mathrm{OH}, 4^{\prime}-\mathrm{OCH}_{3}$ flavone & 17,77 \\
\hline Acacetin & 5,7 -OH 4'- $\mathrm{OCH}_{3}$ flavone & 32,09 \\
\hline Genkwanin & 5,4 '-OH 7-OCH ${ }_{3}$ flavone & 32,98 \\
\hline
\end{tabular}
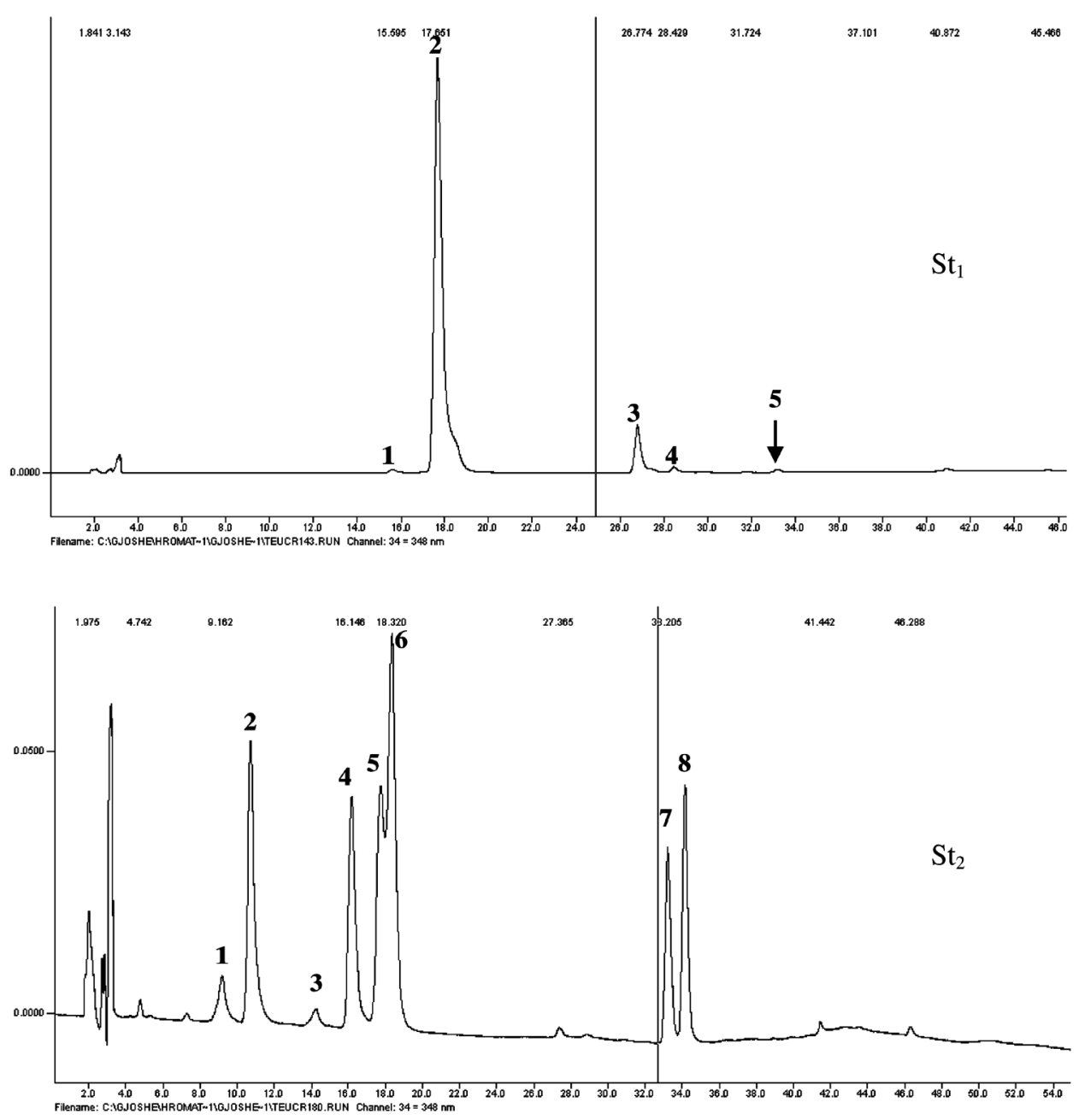

Fig. 1. HPLC chromatograms $(348 \mathrm{~nm})$ of two mixtures of standard substances of flavones. St 1 : 1-apigenin, 2 - diosmetin, 3- cirsimaritin, 4 - cirsilineol, 5 - genkwanin; $\mathrm{St}_{2}$ : 1 - eryodictiol, 2 - luteolin, 3 - naringenin, 4 - apigenin, 5 chrysoeriol, 6 - diosmetin, 7 - acacetin, 8 - genkwanin 
The HPLC chromatogram of hydrolyzed extract of $T$. polium is presented at Fig. 2 . The results of semi-quantitative analysis of the content of each flavones and the amount of total flavonoids are presented in Table 3.

Comparing to literature data, flavones identified in extracts of Macedonian T. polium are well known components of this species. Previously, in T. polium cirsimaritin, cirsiliol, cirsilineol, 5-hydroxy-6,7,3',4'-tetramethoxyflavone, salvigenin, apigenin 5-galloyl-glycoside, apigenin-7-glycoside, vicenin-2 and luteolin-7-glycoside were reported (Esmaeili and Yazdanparast, 2004; Esmaeili at al., 2009; Harborne et al., 1986; Verykokidou-Vitsaropoulou and Vajias, 1986; Rizk et al., 1986, Kwahtsy et al., 1997; Panovska et al., 2007).

\section{Seasonal variation of flavonoids}

For determination of the eventually presented seasonal variation, the composition and the content of flavonoids were determined by HPLC in the samples of T. polium col- lected from the same location (v. Koleshino, south-eastern part of Republic of Macedonia), each month (except June) during 2004. The same HPLC method mentioned above was used and the hydrolyzed extracts were prepared on a same way, as it was made in a purpose of identification and quantification of the flavonoids.

In all investigated samples of T. polium that were collected for purpose of determination of seasonal variations, the same flavone aglycons were identified (Table 4), but in variable ratio during the season. For expression of the relative ratio of flavones, the peak area of cirsilineol measured in October was the lowest, and this area was expressed as one. The all other peak areas of all determined flavones were expressed in appropriately larger values presented in Table 4. The content of total flavonoids is presented as a sum of these numerical values for each month separately. The seasonal variation in the content of six flavones aglycones in T. polium is presented at Fig. 4, while the relative abundance of the flavonoids is presented on Fig. 5.

Table 3. Semi-quantitative determination of flavones aglycons in hydrolyzed extracts of T. polium

\begin{tabular}{|c|c|c|c|c|c|c|}
\hline Sample & Luteolin & Apigenin & Cirsiliol & Diosmetin & Cirsimaritin & Cirsilineol \\
\hline $\mathrm{Tp}$ & ++ & ++ & ++ & + & ++ & $\operatorname{tr}$ \\
\hline $\mathrm{T}_{7}$ & ++ & + & + & $\operatorname{tr}$ & + & $\operatorname{tr}$ \\
\hline $\mathrm{T}_{9}$ & ++ & ++ & + & - & + & $\operatorname{tr}$ \\
\hline $\mathrm{T}_{11}$ & ++ & ++ & + & + & + & $\operatorname{tr}$ \\
\hline $\mathrm{T}_{12}$ & ++ & + & + & $\operatorname{tr}$ & + & $\operatorname{tr}$ \\
\hline $\mathrm{T}_{15}$ & ++ & + & + & + & + & $\operatorname{tr}$ \\
\hline
\end{tabular}

$(++)$ - Dominantly present; $(+)$ - present; tr - presented in traces; $(-)$ - not detected

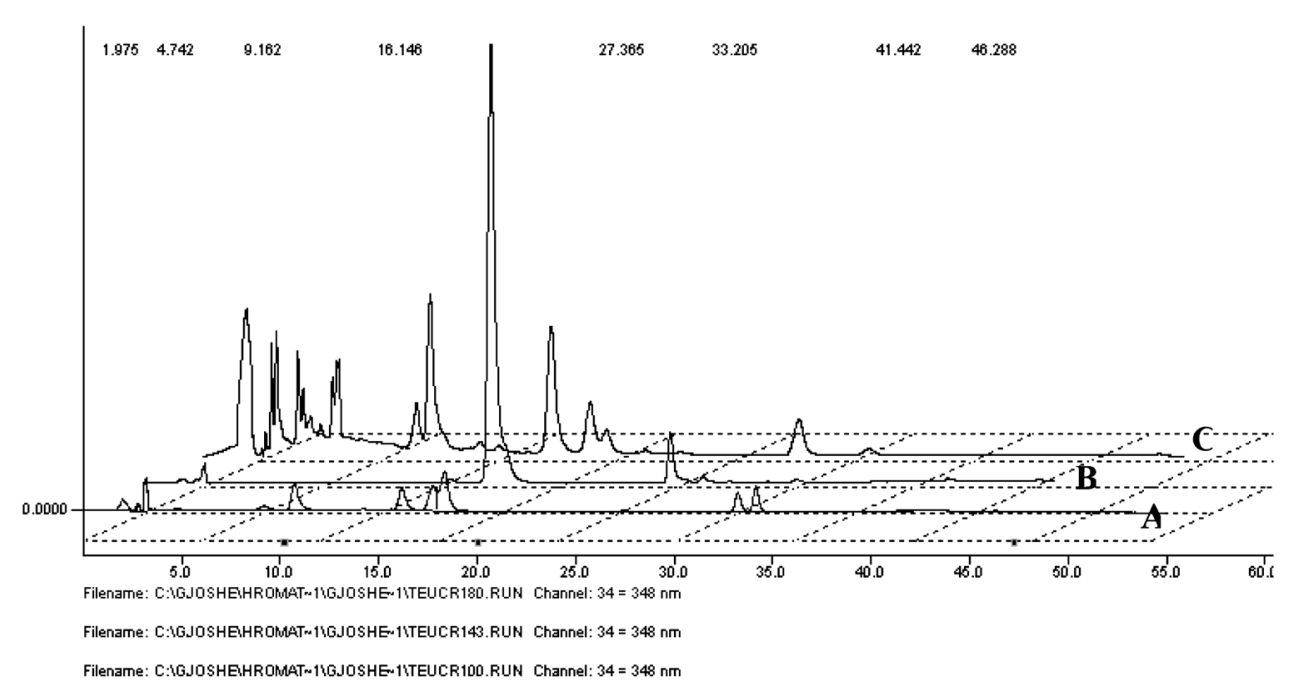

Fig. 2. HPLC chromatogram of hydrolyzed extract of T. polium $-\mathrm{C}$, and mixtures of standard substances: $\mathrm{St}_{1}-\mathrm{B}$ and $\mathrm{St}_{2}-\mathrm{A}$. 
Table 4. Total amount and relative abundance of flavone aglycones during the one season of Teucrium polium, with normalized peak areas values of flavonoids accounted on peak area of cirsilineol, expresed as value one.

\begin{tabular}{|c|c|c|c|c|c|c|c|c|c|c|c|}
\hline & III & $\begin{array}{c}\text { IV } \\
\text { Spring }\end{array}$ & $\mathrm{V}$ & VII & $\begin{array}{c}\text { VIII } \\
\text { Summer }\end{array}$ & $\begin{array}{l}\text { Mounts } \\
\text { IX }\end{array}$ & $\mathrm{X}$ & $\begin{array}{c}\text { XI } \\
\text { autum }\end{array}$ & XII & I & II \\
\hline Luteolin & 64 & 95 & 107 & 90 & 60 & 39 & 28 & 41 & 102 & 82 & 59 \\
\hline Apigenin & 2 & 5 & 30 & 56 & 21 & 25 & 14 & 28 & 6 & 4 & 3 \\
\hline Cirsiliol & 17 & 47 & 38 & 38 & 22 & 11 & 6 & 22 & 43 & 25 & 19 \\
\hline Diosmetin & 5 & 19 & 17 & 8 & 5 & 3 & 4 & 6 & 13 & 15 & 7 \\
\hline Cirsimaritin & 12 & 23 & 28 & 42 & 17 & 18 & 5 & 21 & 27 & 21 & 15 \\
\hline Cirsilineol & 5 & 9 & 6 & 8 & 7 & 3 & 1 & 11 & 9 & 8 & 8 \\
\hline Total: & 105 & 198 & 226 & 242 & 143 & 99 & 58 & 129 & 200 & 155 & 111 \\
\hline
\end{tabular}

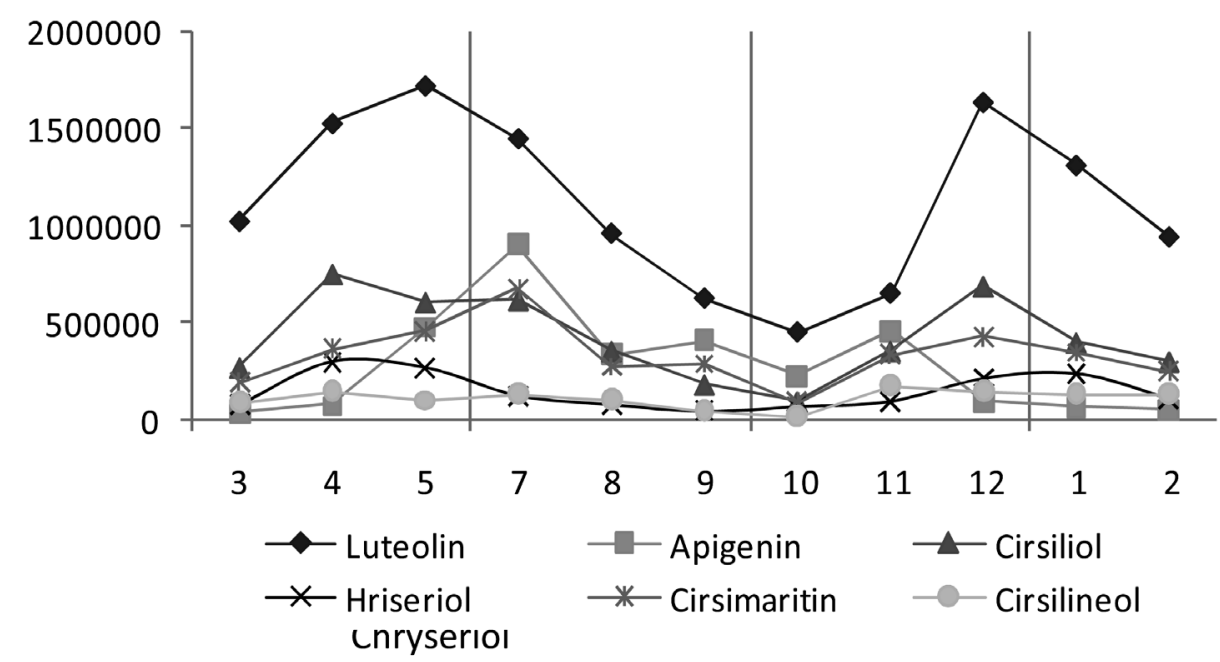

Fig. 3. Seasonal variations in the content of six flavone aglycones in Teucrium polium (1-12 number of mounths)

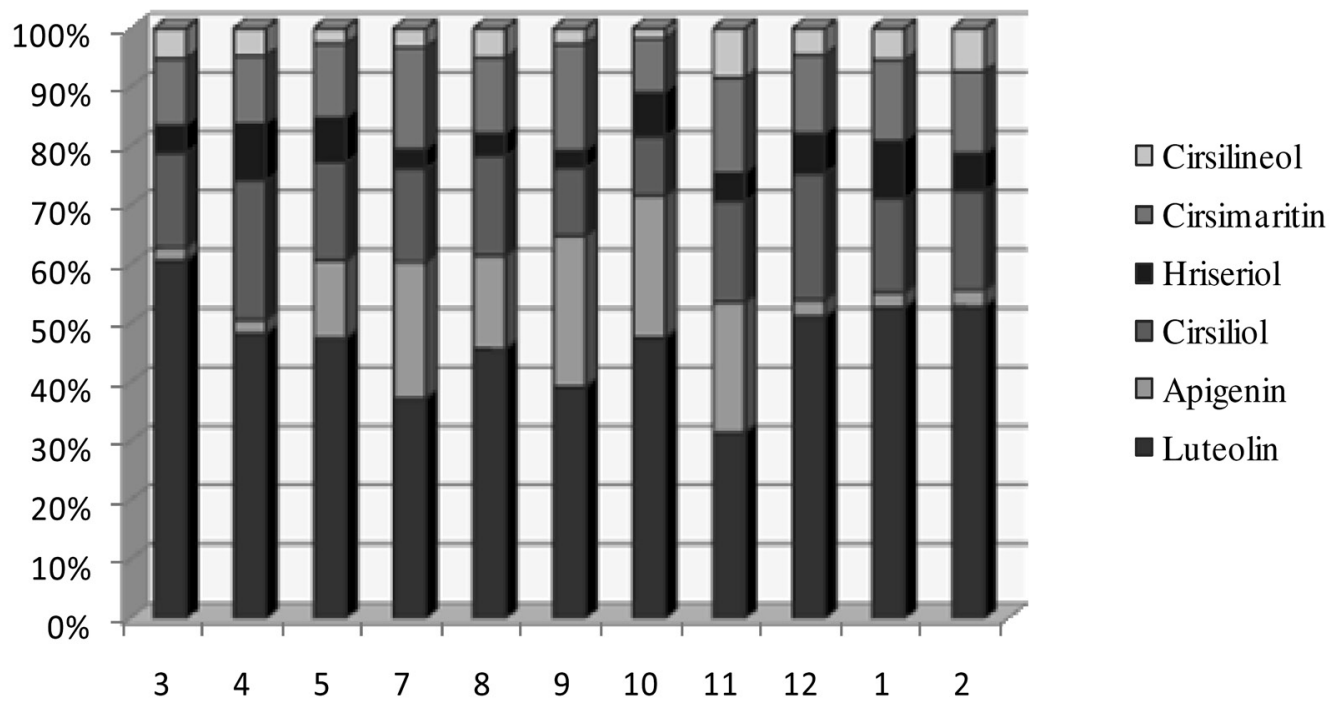

Fig. 4. Relative ratio of the flavonoids in Teucrium polium during one season (1-12 numbers of months) 
From the presented results (Table 4 and Fig. 3 and Fig. 4 ), it could be noticed that there are no qualitative variations in the flavone aglycons in T. polium during one season, as all six flavone aglycones were identified in each month. On the other side, the content of the each flavone aglycone and the content of the total flavonoids vary a lot during the whole season. For instance, cirsilineol ranged from 1 in October to 9 in April and in December, cirsimaritin from 5 in October to 42 in July, while luteolin from 28 in October rise to 107 in May. The variations of each flavonoid were different and the highest amount of lutolin was found in May, for apigenin in July, for cirsiliol and diosmetin in April, for cirsimaritin in July and for cirsiliol in November. The content of total flavonoids was the highest in the period from May to July, when in the composition of flavonoids, luteolin was dominated aglycone, followed by apigenin and than by cirsiliol and cirsimaritin. From the Fig. 5, it could be seen that luteolin was the dominated aglycon during the whole season. According to these results, the over ground parts of T. polium collected in the period from May to July will have the highest quantity of total flavonoids. This period correspond to flowering phase of T. polium. The period from August to November is period of fruiting and is not convenience for collecting of the plant material, as the content of total flavonoids declines.

\section{Conclusion}

Six flavone aglycones (luteolin, apigenin, diosmetin, cirsiliol, cirsimaritin and cirsilineol) were identified by HPLC method in the hydrolyzed extracts of the over ground part of Teucrium polium from R. Macedonia. The most abundant flavone was luteolin, followed by apigenin and cirsimaritin. Great seasonal variations were found in the content of each flavonoid and in the total flavonoids amount. The content of all flavonoids was the highest in the period from May to July, which could be recommended as the most convenient period for collecting of plant material from $T$. polium, rich in flavonoids. Opposite to this, the period of maturation was characterized with the lowest total amount of the flavonoids and represents the period in the year when the collection of plant material should be highly avoided.

\section{References}

Abdollahi, M., Karimpour, H., Monsef-Esfehani, H.R., 2003. Antinociceptive effects of Teucrium polium L. total extract and essential oil in mouse writhing test, Pharmacol. Res. 48, 31-35.

Akabori, Y., 1978. Flavonoid pattern in the Pteridaceae iv. seasonal variation of the flavonoids in the fronds of Adiantum monochlamys, Journal of Plant Research 91 (2), 137-139. DOI: $10.1007 / \mathrm{bf} 02498258$

Ardestani, A., Yazdanparast, R., Jamshidi, S., 2008. Therapeutic effects of Teucrium polium

extract on oxidative stress in pancreas of streptozotocin-induced diabetic rats. J. Med. Food 11, 525-532.

Autore, G., Capasso, F., De Fusco, R., Fasulo, M.P., Lembo, M., Mascolo, N., Menghini, A., 1984. Antipyretic and antibacterial actions of Teucrium polium (L.). Pharmacol. Res. Commun. 16, 21-29.

Bagdonaite, E., Janulis, V., Ivanauskas, L., Labokas, J., 2009. Variation in contents of hypericin and flavonoids in Hypericum maculatum (Hypericaceae) from Lithuania, Acta Botanica Hungarica 51 (3-4), 237-244. Accessed at: http://www.akademiai.com/content/f47256151p75t887/ fulltext.pdf?page $=1$

Baluchnejadmojarad, T., Roghani, M., Roghani-Dehkordi, F., 2005. Antinociceptive effect of Teucrium polium leaf extract in the diabetic rat formalin test. J. Ethnopharmacol. 97, 207210.

Capasso, F., Cerri, R., Morrica, P., Senatore, F., 1983. Chemical composition and anti-inflammatory activity of an alcoholic extract of Teucrium polium L. Boll. Soc. Ital. Biol. Sper. 59, 1639-1643.

Cozzani, S., Muselli, A., Desjobert, J., Bernardini, A., Tomi, F., Casanova, J., 2005. Chemical composition of essential oil of Teucrium polium subsp.capitatum (L.) from Corsica, Flavour and Fragrance Journal 20 (4), 436-441.

De Castro, W.V., Mertens-Talcott, S., Rubner, A., Butterweck, V., Derendorf, H., 2006. Variation of flavonoids and furanocoumarins in grapefruit juices: a potential source of variability in grapefruit juice-drug interaction studies, $\mathrm{J}$ Agric Food Chem. 54(1), 249-55.

Esmaeili, M.A., Yazdanparast, R., 2004. Hypoglycaemic effect of Teucrium polium: studies with rat pancreatic islets, J. Ethnopharmacol. 95, 27-30.

Esmaeili, M.A., Zohari, F. and Sadeghi, H., 2009. Antioxidant and protective effects of major flavonoids from Teucrium polium on beta-cell destruction in a model of streptozotocininduced diabetes. Planta Med. 75, 1418-1420.

Harborne, J.B., Tomas-Barberan, F.A., Williams, C.A., Gil, M.I., 1986. A chemotaxonomic study of flavonoids from European Teucrium species, Phytochemistry 25 (12), 2811-2816.

Ioku, K., Takada, Y., Aoyama,S., Takei, Y., 2005. Seasonal Variation in Flavonoid Contents of Green Pepper and Other Vegetables, Journal of the Japanese Society for Food Science and Technology 52 (4), 190-195. Accessed at: http:// sciencelinks.jp/j-east/article/200510/000020051005A03878 31.php

Kabouche, A., Kabouche, Z., Ghannadi, A., Sajjadi, S.E., 2007. Analysis of the essential oil of Teuctrium polium ssp. aurasiaticum from Algeria, J. Essent. Oil. Res. 19, 44-46.

Kawashty, S.A., Gamal, El-Din E.M., Saleh, N.A.M., 1999. The flavonoid chemosystematics of two Teucrium species from Southern Sinai, Egypt, Biochemical Systematics and Ecology 27, 657-660.

Liu, L.S., Crowe, N.L., Ju, H.Y., Pong, D.F., Liu, W.S., Zhang, J.Y., 1994. Variation of flavonoids and other phenolics in the leaves of Chinese plum (Prunus salicina Lindl.) cultivars, Advances in horticulture 472-480. Accessed at: http://www. cabdirect.org/abstracts/19961604858.html;jsessionid $=4081$ 32E3CF57935110BF1F1AF05D025C

Luengas-Caicedo, P.E., Castro Braga, F., Brandazo, G.C., de Oliveira, A.B., 2007. Seasonal and Intraspecific Variation of Flavonoids and Proanthocyanidins in Cecropia glaziovi Sneth. Leaves from Native and Cultivated Specimens, Z. Naturforsch. 62c, 701-709. Accessed at: http://www. znaturforsch.com/ac/v62c/s62c0701.pdf 
Malakov, P.Y., Papanov, G.Y., 1983. Furanoid diterpenes from Teucrium polium, Phytochemistry 22 (12), 2791-2793.

Marquez, C., Valverde, S., 1979. A new clerodane diterpene from Teucrium polium L., J. Chem. Soc., Perkin Trans. 1, 2526-2527. DOI: 10.1039/P19790002526

Moghtader, M., 2009. Chemical composition of the essential oil of Teucrium polium L. from Iran, American-Eurasian J. Agric. \& Environ. Sci. 5 (6), 843-846. Accessed at: http:// www.idosi.org/aejaes/jaes5(6)/18.pdf

Oganesyan, G.B., Galstyan, A.M., Mnatsakanyan, V.A., Shashkov, A.S., Agababyan, P.V., 1991. Phenylpropanoid glycosides of Teucrium polium, Chemistry of Natural Compounds 27, 556-559. DOI: 10.1007/BF00630353

Panovska, T.K., Kulevanova, S., Gjorgoski, I., Bogdanova, M., Petrushevska, G., 2007.

Hepatoprotective effect of the ethyl acetate extract of Teucrium polium L. against carbontetrachlorideinduced hepatic injury in rats. Acta Pharm. 57, 241-248.

Rajabalian, S., 2008. Methanolic extract of Teucrium polium L. potentiates the cytotoxic and apoptotic effects of anticancer drugs of vincristine, vinblastine and doxorubicin against a panel of cancerous cell lines. Exp. Oncol. 30, 133-138.

Rasekh, H.R., Khoshnood-Mansourkhani, M.J., Kamalinejad, M., 2001. Hypolipidemic effects of Teucrium polium in rats,
Fitoterapia 72, 937-939.

Rizk, A.M., Hammouda, F.M., Rimpler, H., Kamel, A., 1986. Iridoids and flavonoids of Teucrium polium herb, Planta Med. (2), 87-88.

Sharififar, F., Dehghn-Nudeh, G., Mirtajaldini, M., 2009. Major flavonoids with antioxidant activity from Teucrium polium L., Food Chemistry 112, 885-888.

Stefova, M., Stafilov, T., Kulevanova, S., Stefkov, G., Bankova, V., 2007. QSRR of Flavones: Evaluation of Substituent Contributions to RP HPLC Retention, Journal of Liquid Chromatography \& Related Technologies 30 (8), 10351049.

Tariq, M., Ageel, A.M., al-Yahya, M.A., Mossa, J.S., al-Said, M.S., 1989. Anti-inflammatory activity of Teucrium polium. Int. J. Tissue React. 11, 185-188.

Xu, Y., Guo, Z., Tan, L., Bu, X., Long, L., 2009. Seasonal Variation of Total Flavonoids Contents for Different Parts of Broussonetia papyrifera, Research and Practice on Chinese Medicines, DOI: CNKI:SUN:JZZY.0.2009-04-009. Accessed at:http://en.cnki.com.cn/Article_en/CJFDTOTALJZZY200904009.htm

Verykokidou-Vitsaropoulou, E, Vajias, C., 1986. Methylated Flavones from Teucrium polium, Planta Med. (5), 401-402.

\title{
Сезонски варијации на флавоноиди во Teucrium polium L. (Lamiaceae)
}

\author{
Ѓ оше Стефков ${ }^{1 *}$, Марија Карапанџова ${ }^{1}$, Марина Стефова², Светлана Кулеванова \\ ${ }^{1}$ Институт за фармакогнозија, Фармацевтски факултет, Универзитет Св. Кирил и Методиј, Скопје, \\ Република Македонија \\ ${ }^{2}$ Институт за хемија, Природно-математички факултет, Универзитет Св. Кирил и Методиј, \\ Скопје, Република Македонија
}

Клучни зборови: Teucrium polium, флавоноиди, HPLC анализа, сезонски варијации

Целта на трудот е идентификација на флавонски агликони и определување на содржина на поединечни и на вкупни флавоноиди, како и испитување на можни сезонски варијации на флавоноиди во Teucrium polium L. (Lamiaceae). Примероците од растението се собирани од шест различни локалитети во Република Македонија, во текот на летото во 1999, во 2000 и во 2003 година. За утврдување на сезонските варијации примероците се собирани во с. Колешино, во 2004 година, секој месец во текот на целата година. Во хидролизираните екстракти од надземните делови од Teucrium polium, co HPLC метод се идентификувани шест флавонски агликони (лутеолин, апигенин, диосметин, цирсилиол, цирсимаритин и цирсилинеол), меѓу кои доминираат флавонот лутеолин, а потоа апигенин и цирсимаритин. Во содржината на поединечните, како и во содржината на вкупните флавоноиди најдени се големи сезонски варијации. Доминантен флавон во текот на целата сезона е лутеолин, најмногу застапен во текот на месец мај. Содржината на вкупните флавоноиди е најголема во периодот од мај до јули и овој период може да се препорача како најсоодветен период во вегетациониот развој на растението за собирање на растителниот материјал од Teucrium polium. 



\title{
Фармакогностички интересни ендемични растенија во Република Македонија
}

\author{
Јана Јовановска, Гоше Стефков*, Марија Карапанџова \\ Институт за фармакогнозија, Фармацевтски факултет, Универзитет Св. Кирил и Метидиј, 1000 Скопје, \\ Република Македонија
}

Received: November 2009; Accepted: December 2009

\begin{abstract}
Апстракт
Во флората во Република Македонија има околу 3200 видови во 147 фамилии. Од нив според едни извори, 115 се познати ендемични виши растенија од кои 114 припагаaа во групата скриеносемени. Според други извори има 135 видови ендемични растенија од кои се смета дека околу 111 се локални ендемични видови, а 24 во пограничните планини. Точниот број сеуште не е утврден. Источниот дел на Македонија, источно од реката Вардар скоро и да нема ендемити, додека останатата територија западно од Вардар е многу богата со вакви видови. Од планините најбогата е Галичица, од клисурите - клисурата на реката Треска, а од низините посебно се истакнува околината на Прилеп.

И покрај богатството на ендемични и реликтни видови сеуште не се објавени било какви фармакогностички податоци за овие растенија. Од наведените ендемични видови, околу 30 би можеле да бидат фармакогностички интересни за испитување на хемискиот состав, изолација на потенцијално активни супстанции и испитување на биолошко-фармаколошката активност. Новите инструментални техники што денес се користат во испитување на хемијата на медицинските растенија и природните производи овозможуваат да се користи многу мало количество материјал, што не претставува ризик од загрозување на ендемичните видови. Дополнителен предизвик претставува изготвување на соодветна програма за заштита на сите ендемични растенија, со посебен акцент на фармакогностички интересните видови.
\end{abstract}

Клучни зборови: ендемични растителни видови, Република Македонија, фармакогнозија

\section{Вовед}

Ендемизам на растенија е еколошка состојба на уникатност на ботаничките видови врзани за определено географско подрачје, национални граници или географски зони, изолирани региони и слично, при што истите не можат да се најдат на никое друго подрачје, регион или област. Спротивно на ендемични растенија кои се врзани за ограничени географски подрачја и специфични еколошки средини, космополитските растенија се широко присутни во речиси сите географски и климатски зони. Физичките, биолошките и кли-

* gstefkov@yahoo.com матските фактори можат да придонесат во голема мера за појава на ендемизмот. Ендемичните видови можат посебно да се развијат на биолошки изолирани места како што се на пример, островите поради нивната географска положба (Endemism, 2009; Endemic Plants 2003; Definition of endemic in US English dictionary, 2009; Endemic, eLook Online Dictionary). Покрај ендемични, разликуваме уште една специфична група растенија означени како реликтни. Реликтни растенија се мала група на растенија што преживеале драматични промени во средината во која живеат и сеуште се задржале на местото на кое биле распостранети во многу далечно минато (Habel and Assmann, http://books. google.com/books). 
Освен што се интересни како флористички елементи, од таксономски аспект и како видови што го збогатуваат флорниот биодиверзитет, некои ендемични и реликтни растенија се интресни и од фармакогностички аспект. Можност да се проучува хемизмот и биолошката активност на ваквите видови овозможува добивање корисни научни податоци за збогатување на научниот фонд за испитуваните видови од флората на Република Македонија, но претставува и можност да се добијат информации што можат да се искористат во хемотаксономски цели, да се изнајдат нови соединенија и процени потенцијалот на нивната биолошка активност, што претставува уникатен научен податок со капацитет од пошироко значење во медицински или во други цели. Со оглед на можностите што ги нудат новите инструментални, високо софистицирани техники, потребното количество материјал за хемиски скрининг е многу мало (помало од еден грам) што не претставува дополнителна закана за нанесување штета на овие растенија кога материјалот за испитување се собира од природните наоѓлишта. Оттука, цел на овој труд е потенцирање на ендемични и реликтни видови од македонската флора што би биле интересни за вклучување во фармакогностички испитувања, со цел добивање нови и корисни податоци од каде би можело во иднина да се преземат и други активности за евентуално внесување на ваквите растенија во култура или нивно производство по пат на биоинжинеринг или пак производство на биолошко активни супстанци на ваквите растенија по биотехнолошки пат.

\section{Краток преглед на богатството на биолошка разновидност во Република Македонија}

Богатството од екосистеми, живеалишта, заедници и посебни растителни места во Република Македонија прават таа да биде на врвот на листата земји со импресивен биодиверзитет во Европа (,hot spot“). Врз основа на расположливите научни податоци утврдени се неколку екосистеми: водни и блатни, крајбрежни, тревести, ридски, степски, шумски и планински од кои клучни се водните и блатните, тревестите, шумските и планинските. Повеќе од 260 растителни заедници се документирани од кои доминираат тревестите и шумските заедници. Растителната разновидност е застапена со повеќе од 16000 таксони на диви растенија, габи и животни. Од особено значење е фактот дека повеќе од 900 се регионални ендемични видови виреат во Р. Македонија (Втор национален извештај кон конвенцијата за климатски промени, СекторгБиодиверзитетг).

\section{Биогеографски региони}

Во Република Македнонија може да се разликуваат два био-географски региони: континентален и алпски, и еден субрегион, суб-медитерански. Во зависност од локацијата и надморската висина се разликуваат осум растителни зони (во однос на климата и почвата). Две области во суб - медитеранскиот појас: суб-медитеранска област од 50-500 метри надморска висина - зафаќа површина од 800000 хектари, и континентално суб медитеранска област од 501 - 600 метри надморска висина зафаќа површина од 97000 хектари, повеќе од 35 \% од суб - медитеранскиот појас. Во континенталниот појас се разликуваат четири области: топла континентална област од 601-900 метри надморска висина зафаќа површина од 740000 хектари $(27,4$ \%), студена континентална област од 901-1 100 метри надморска висина зафаќа површина од 342000 хектари (13,3%), ниска планинска област од 1 101-1300 метри надморска висина зафаќа површина од 250000 хектари $(9,7$ \%) и планинска континентална област од 1 301-1 650 метри надморска висина зафаќа површина од 269000 хектари $(10,4 \%)$. Во алпскиот појас се разликуваат две области: суб - алпска област од 1 651-2 250 метри надморска висина зафаќа површина од 9700 хектари $(3,8$ \%) и алпска планинска област над 2250 метри надморска висина зафаќа површина од 13000 хектари и само 0,5 \% од појасот (Nature protection and biodiversity FYR Macedonia, http://www.eea.europa.eu/soer/countries/mk/ soertopic_view?topic=biodiversity).

\section{Разновидност во растителниот свет во Р. Македо- нuja}

Разновидноста во растителниот свет во Република Македонија како дел од биолошката разновидност во целина е многу богата. Тоа се однесува подеднакво и на микроорганизмите, нижите растенија како што се алгите и лишаите, габите и вишите растенија.

Табела 1. Растителен биодиверзитет на Р. Македонија (Nature protection and biodiversity FYR Macedonia, http://www.eea.europa.eu/soer/countries/mk/soertopic_view?topic=biodiversity)

\begin{tabular}{lcc}
\hline \hline \multicolumn{1}{c}{ Таксономска } & Број на видови & Ендемити \\
\hline Алги & 2198 & 196 \\
Лишаи & 354 & $/$ \\
Габи & 1250 & $/$ \\
Мовови & 398 & 2 \\
Папрати & 45 & 1 \\
Тресет мов & 6 & $/$ \\
Членковидни & 7 & $/$ \\
Голосемени & 18 & $/$ \\
Скриеносемени & 3200 & 114 \\
Вкупно & 7480 & 251 \\
\hline
\end{tabular}

Се проценува дека вишите растенија во флората во Република Македонија опфаќаат околу 3000 видови во 147 фамилии: Lycopsida (со 3 фамилии, 5 родови и 6 видови), Sphenopsida (со една фамилија, еден род 
и 13 таксони - 7 видови и 6 пониски таксони), папрати (Filicinae, со 15 фамилии, 21 род и 60 таксони - 42 видови и 18 пониски таксони), Coniferophyta - co 4 фамилии, 6 родови и 22 таксони - 15 видови и 7 пониски таксони, 50 фамилии од класата Dicotyledonae со 235 родови и 1630 таксони - 1028 видови и 602 пониски таксони. Во рамките на Македонската Академија на науките и уметностите преку изданието „Флора на Република Македонија“ претставени се резултатите од интензивните истражувања и во останатите фамилии во оваа класа (Мицевски, 1985; 1993). Ендемичните и реликтните видови се исклучително значајна компонента во растителната разновидност на Македонија. Според податоците на Матевски (1990) и Матевски и Костадиновски (1996) има 135 ендемични виши растителни видови на територијата на Република Македонија од кои 111 се наоѓаат на територијата на Македонија, а останатите видови се наоѓаат на планинските места на границите со Грција, Албанија, Србија, Косово и Бугарија.

\section{Ендемични, реликтни и ретки растителни видови во Р. Македонија}

Од 115 познати ендемични виши растенија, 114 припаѓаат во групата скриеносемени растенија. Во класата дикотиледони има 109 ендемични видови, а во класата на монокотиледони има само 5. Фамилии со најмногу ендемични видови се: Asteraceae (18), Caryophyllaceae (17), Lamiaceae (12), Violaceae (10), Scrophulariaceae (9) и Rosaceae (9) (Assessment and evaluation of biodiversity on national level, http://www.undp.org.mk/content/ Publications/Biodiverzitet\%20eng(6).pdf).

Табела 2. Позначајни реликтни растителни видови во Р. Македонија

\begin{tabular}{|c|c|}
\hline \multicolumn{2}{|c|}{ Реликтни растителни видови } \\
\hline Thymus oehmianus* & Campanula formanekiana \\
\hline Crocus cvijici* & Ramonda nathaliae (serbica)* \\
\hline Pinus heldreichii* & Pinus peuce* \\
\hline Ruscus hypoglossum* & Narthecium scardicum \\
\hline Taxus baccata* & Trolius europaeus* \\
\hline Gentiana asclepiadea* & Swerthia punctata* \\
\hline Viola kosaninii* & Rhamus rupestris \\
\hline Acer heldreichii* & Ostrya carpinifolia \\
\hline \multicolumn{2}{|c|}{ Бореал, арктички реликтни растителни видови } \\
\hline Trifolium pilczii* & Vaccinium uliginosum $*$ \\
\hline Dryas octopetala & Carex curvula \\
\hline Arctostaphylus uva ursi* & Carex rigida var. macedonica \\
\hline Salix reticulata* & Salix herbacea* \\
\hline Carex laevis & Salix retusa* \\
\hline Arabis alpina & Primula minima* \\
\hline
\end{tabular}

*видови коишто имаат свои сродници во истиот род што се фармакогнозрички значајни

Присуството на ендемични, реликтни и ретки растителни видови во Р. Македонија е од особено зна- чење за науката. Во согласност со студиите што до сега се направени може да се заклучи дека е голем бројот на таквите видови (Мицевски, 1995; 1998). Позначајните реликтни и ретки растителни видови во Република Македонија се прикажани во Табела 2.

\section{Територијална поделба на ендемитите во Р. Македонија и проблемот со нивната загрозеност}

Територијата на Р. Македонија е богата со ендемити, а тоа е условено со геолошкото минато на овој дел на Балканскиот Полуостров и неговата флорогенеза. За сега се смета дека има околу 111 локални ендемични видови и 24 во пограничните планини. Источниот дел на Македонија, источно од реката Вардар скоро и да нема ендемити, додека останатата територија западно од Вардар е многу богата со вакви таксони. Од планините најбогата е Галичица, од клисурите - клисурата на реката Треска, а од низините посебно се истакнува околината на Прилеп. Ендемитите во Македонија може да се групираат во 5 посебни групи (Micevski \& Matevski, 1987). На многу мал дел од ендемитите во Р. Македонија им се заканува опасност од уништување.

Ендемизмот во флората во Македонија е во непосредна врска со геолошката историја, со климатскате состојби во минатото и денес на оваа територија, орографијата, геолошката подлога и педолошките особености на Р. Македонија. Сите овие фактори заедно со миграцијата што се случувала кон крајот на терциерот (пред 2,5 милиони год.), за време на плеистоценскиот и во постглацијалниот период, одиграле значајна улога во зачувување на поедини реликтни видови на ограничен простор во Р. Македонија. Во текот на плеистоценскиот период, глацијалниот феномен зафатил и поедини врвови на високите планински масиви. Меѓутоа поради поволните услови на теренот и климата, голем дел од претставниците на старата терциерна флора успеал да преживее и да се одржи до денес. Скоро секој поголем планински масив во Р. Македонија има свои локални ендемични видови кои се исклучиво врзани за тој масив. Овој феномен некои поедини видови да се строго врзани за одреден планински масив или планина некои ботаничари (на пр., Koshanin, во Biodiversity www. catsg.org) ги поврзува со претпоставката дека и за време на терциерот овие видови имале локално распостранување. Денес е многу тешко да се потврди или негира оваа претпоставка бидејќи во терциерот и во плеистоценскиот период имало големи промени во климата, во развојот и во составот на растителниот свет. Меѓутоа останува фактот дека речиси секоја наша планина има свои ендемични видови. Покрај планинските ендеми кои биле најпознати и најбројни исто како и ендемитите во клисурите, денес се повеќе се откриваат ендеми што растат во низините и во ридските места 
во Македонија, од кои некои се прилагодени на многу специфични услови во животната средина и се со многу ограничено распостранување.

Иако има податоци за 135 ендемични видови, се смета дека е сеуште рано да се говори за точниот број на растителни ендемити, бидејќи деталните испитувања и монографската обработка на многу родови откриваат нови локални ендеми. Со интензивирање на таксономските и хоролошките истражувања, се случува и да се намалува бројот на ендемите со откривање на нивни нови наоѓалишта во другите региони или соседни земји. Така на пример познатиот ендемит за соседна Албанија - Colchicum pieperianum Markgr. кој бил познат само за локалитетот Deja бил најден и на планината Бистра и денес синонимот на овој таксон е Colchicum macedonicum Kosanin.

Според расположливите податоци за нашата флора би можеле орентационо да се наведат 111 локални ендемични видови, кои според сегашните познавања за нивниот опсег се со многу ограничено распостранување и исклучиво се на територијата на Македонија. Покрај овие ендеми постои уште еден број од 24 ендеми кои во Македонија се наоѓаат во пограничните планини, кон Грција и Албанија, и за кои се верува дека се задржани само на пограничниот планински појас. Така вкупниот број на ендеми е 135 видови. Ако се земат в предвид и подвидовите и вариететите, бројот би бил значително поголем, а истовремено би се дошло и до значајни фитогеографски заклучоци. Секој ендемит спрема својата генетска припадност укажува на роднинска врска со блиски видови кои се развиваат во други делови од светот. Таков случај е и со нашите ендемити. Така на пример еден вид упатува на роднинска врска со елементите на флората во Крим и Кавказ, друг со флората на Крит, трет со флората во Мала Азија и Блискиот Исток итн., а тоа јасно кажува дека флората во Македонија е многу хетерогена по своето потекло и состав.

Ако се анализира распоредот на ендемите на територијата на Македонија може да се дојде до многу интересен заклучок. На прв поглед се забележува дека реката Вардар ја дели територијата на два дела при што во источниот дел скоро и да нема ендемити, а скоро сите ендемити се наоѓаат во западниот дел. Ваквиот распоред на ендемите единствено може да се објасни со мислењето на Стојанов, според кое некогашното Серматско Море за време на неговото максимално простирање го делело Балканскиот Полуостров на два дела, и тоа по долината на реките Морава и Вардар. Распоредот на ендемите е последица на распоредот на копното и водата во минатото.

Во источна Македонија има само 6 ендемити и 7 во средниот тек на реката Вардар. Но тие имаат тенденција кон западниот дел на групата ендемити. Во источна Македонија на планината Осогово и тоа на врвот Султан Тепе (Царев врв) расте ситен ендемичен вид Genistra fukarekiana. Потоа кон Гевгелија се наоѓа Astragalus psysocalyx, два вида од родот Viola на Бела- сица, еден Verbascum и една Centaurea кај Дојранско Езеро. Посебно се интересни ендемите на Вардар во триаголникот помеѓу Велес, Штип и Неготино. Овие ендемити се посебно значајни бидејќи се претставници на стара степска флора кои благодарение на специфичните и поволни еколошки услови на средината и поволното историско - геолошко минато успеале да се одржат до денес. Тука спаѓаат многу интересни видови: Salvia jurisicii, Astragalus cernjavski, Tulipa marianae, Alyssum bargalense, Ferulago macedonica, Hedysarum macedonicum и Potentilla tridentula, а на нив им се приклучува и еден голем број на реликтни видови кои кај нас единствено се наоѓаат на тој локалитет. Останатите видови кои се наоѓаат во клисурите на Вардар воглавно се распостранети на десната страна од реката. Во однос на групирањето на ендемите односно нивната поделба разни автори како на пример Адамовиќ, Turrill, Гајиќ и др. имале различни погледи односно критериуми за формирање групи (Micevski \& Matevski, 1987).

\section{Поделба на ендемитите според големината на прос- mopom што го зафаќaаm}

Ендемите во Македонија се поделени врз основа на големината на просторот и областа што ја зафаќаат (Micevski \& Matevski, 1987). На тој начин се поделени во 5 групи :

- І група, опфаќа ендеми кои се многу ограничено распостранети, т.е. ендеми познати само од еден локалитет.

- $\quad$ II група опфаќа ендеми кои се пошироко распостранети на територијата на Македонија.

- III група опфаќа ендеми кои се наоѓаат во западните погранични краеви.

- $\quad$ IV група опфаќа ендеми од јужните погранични планини.

- V група опфаќа ендеми на Балканскиот Полуостров.

I група ендемични растенија, ендеми само на еден локалитет

Од сите групи на ендеми најинтересни се оние кои завземаат многу мал и ограничен простор и често тоа се видови кои се прилагодени на многу специфични услови на животната средина. Тоа се главно видови кои се наоѓаат на палеогени седименти како на пример Astragalus cernjavski и Tulipa marianae, кои се познати само на еден локалитет помал од $0,5 \mathrm{~km}^{2}$. Слично е и со видовите Hedysarum macedonicum, Salvia jurisicii и Ferulago macedonica, меѓутоа нив ги има на значително поголемо подрачје во централниот дел на Македонија кое има изглед на степа.

Посебен случај претставува видот Sambucus deborensis кај Дебар кој егзистира на површина не поголема од $50 \mathrm{~m}^{2}$, и тоа е единствен познат локалитет. 
Уште еден интересен случај е видот Astragalus psysocalyx кој бил опишан 1837 година од Fischer, од околината на Пловдив во Бугарија. 50 години подоцна наоѓалиштето од кое е опишан овој вид е целосно уништено и тој вид исчезнал. Подоцна бил пронајден во околината на Петрич. Но според информациите и тој локалитет бил уништен. Денес единствено наоѓалиште е во Македонија во околината на Гевгелија во областа со дабови (Quercus coccifera), каде што успешно расте и покрај дејството на човекот.

Кон овие видови може да се приклучат и уште некои кои ги населуваат врвовите на поедини планини и завземаат мали површини како на пример Colchicum macedonicum (Бегово поле на Јакупица) и Pedicularis ferdinandii по страните на врвот Солунска Глава на Јакупица. (Biodiversity, www.catsg.org).

\section{II група ендемични растенија, ендеми на два и повеќе локалитети}

Во посебна група се сместени ендемите кои се многу пошироко распостранети т.е. се јавуваат на два или повеќе локалитети, а можно е и некои од нив да навлегуваат во соседните земји. Тоа е група од 15 видови кои главно растат на камења и карпи. Во оваат група спаѓаат Centaurea grbavacensis, Astragalus gracaninii, Pulsatilla macedonica, Sempervivum macedonicum, Verbascum pachyurum, Tulipa scardica, Campanula formanekiana, Aristolochia macedonica, Satureja fukarekiana, Satureja adamovicii, Pedicularis limnogena, Alkanna noneiformis и Anthoxanthum pauciflorum (Micevski \& Matevski, 1987).

III група ендемични растенија, ендеми во западни погранични области

Вo III група спаѓаaт 11 ендеми кои ги има во западните погранични планини (Кораб, Дешат и Јабланица) но некои од нив навлегуваат и во внатрешноста на Албанија. Тоа се главно високо палнински видови како Festuca kontrabensis, Trifolium pulczii, Solenanthus scardicus, Fritillaria macedonica, Narthecium scardicum, Colchicum pieperianum, Ranunculus wettsteinii, Asperula doerfleri, Draba korabensis, Centaurea kosaninii и др. (Micevski \& Matevski, 1987).

\section{IV група ендемични растенија, ендеми во јужни пог-} ранични области

Bo IV група има 13 ендеми кои според тоа што ги има во внатрешноста на Македонија и пограничните планини, навлегуваат и во Албанија и во Грција. Тоа ce Stachys horvaticii, Viola velutina, Viola eximia, Viola brachyphylla, Veronica kindlii, Alyssum doerfleri, Crocus maudi, Centaurea graeca, Lilium heldreichii, Astragalus sericophyllus и др. На нив може да се приклучат и некои ендеми кои се познати за Пелистер, Кајмакчалан и Кожуф и секако Галичица (Micevski \& Matevski, 1987).
V група ендемични растенија, Балкански ендеми

Најголемата група ендеми во флората во Македонија се балканските ендеми кои играат значајна улога во составот на флората во Македонија. Нивниот процент кој во границите на Балканскиот Полуостров изнесува 30 \% не е мал меѓутоа ако се земат в предвид и подвидовите и вариететите тој процент би бил многу поголем (Micevski \& Matevski,1987).

Поделба на ендемитите според вертикалната дистрибуција

Врз основа на вертикалната дистрибуција на ендемите може да се издвојат ендеми на високите планини, ендеми во низините и ридските места и како посебна група ендеми во клисурите.

\section{Високопланински ендеми}

Иако скоро сите високи планини во Македонија имаат свои локални ендемични видови сепак две планини, Галичица и Шар Планина се одликуваат со богатство од ендеми. За Галичица се познати 13 ендеми, а за Шар Планина 10. Шар Планина според својата положба и односот со другите планини претставува бариера која многу видови не успеале да ја преминат во текот на повеќекратните меридијански миграции и поради тоа се задржале на неа. И Галичица претставува сличен случај само со разлика во тоа што на неа се задржале видови што доаѓале од јужните грчки планини. Од 13 ендеми за планината Галичица посебно се значајни Centaurea galicicae, Centaurea tomorosii, Centaurea soskae, Nepeta ernestimayeri, Astragalus mayeri, Laserpitium ochridanicum, Crocus cvijici, Helichrysum zivojini, Edraianthus horvatii, Festuca galicicae, Micromeria kosaninii и др. На Шар Планина и тоа претежно на варовничка подлога се наoŕaat Crocus scardicus, Dianthus scardicus, Verbascum scardiocolum, Potentilla doerfleri, Sempervivum kosaninii, Viola schariensis, Thymus zygiformis и др. (Мицевски \& Матевски, 1987).

Планината Баба со Пелистер, Ниџе со Кајмакчалан и Јакупица во просек имаат 4 или 5 ендемични видови (Мицевски \& Матевски, 1987): Баба со Пелистер: Crocus pelistericus, Dianthus myrtinervius, Sempervivum octopodes и Alchemilla peristerica; Ниџе со Кајмакчалан: Silene horvatii, Dianthus kajmaktzalanicus, Peucedanum lavrentiades и Viola doerfleri; Јакупица: Viola bornmulleri, Veronica vandasii, Sempervivum macedonicum, Pedicularis ferdinandi и Colchicum macedonicum; Кожуф, делот над Маврово и Стогово имаат по еден ендемичен вид.

\section{Ендеми во клисурите}

Друго место кај што се среќаваат ендемите се длабоките речни клисури. За сега се смета дека нај- 
богата е клисурата на реката Треска која има 6 ендеми (Thymus skopjensis, Viola herzogii, Silene lindtneri, Dianthus kapinensis, Thymus oehmianus и Cerastium cernjavskii), потоа Таорската клисура со 4 ендеми (Anchusa macedonica, Tragopogon kindingeri, Hesperis macedonica и Sempervivum kindingeri), долниот тек на Црна Река има 3 ендеми (Verbascum macedonicum, Verbascum herzogii и Cytisus lupinifolis), Демиркаписката клисура има 2 ендеми (Heptaptera macedonica и Centaurea formanekii), додека во клисурите на реките Бабуна, Црн Дрим и Рајец има само по еден ендемит (Viola babunensis, Campanula deborensis и Verbascum chrysanthum). Во досегашната ботаничка литература многу често се пишувало за богатството на клисурите со ендеми, меѓутоа се дошло до заклучок дека клисурите се многу побогати со реликтни видови (Micevski \& Matevski,1987).

\section{Ендеми во низините и ридските места}

Третото место што е поврзано со ендемите се низините и ридските места. Во тој поглед посебно се значајни три локалитети. Првите два локалитети се во околината на Прилеп и тоа еден е во непосредна близина на градот. Тој локалитет се одликува со присуство на големи гранитни блокови помеѓу кои растат 4 ендеми: Centaurea karamani, Verbascum adenanthum, Moeringia minutiflora и Asplenium macedonicum. Вториот локалитет го опфаќа теренот околу Плетвар со врвот Козјаксевероисточно од Прилеп и Сивец каде се сретнуваат 7 ендеми : Stachys iva, Silene viscariopsis, Seseli vandasii, Centaurea kozjakinensis, Centaurea marmorea, Armeria vandasii и Allium bornmulleri. Овие два локалитети заслужуваат посебен третман на заштита поради својата богата и разновидна флора.

Третиот локалитет е местото Мајдан (Алшар) кој поради својот богат и разновиден геолошки состав условува развој на многу интересна ендемична и реликтна флора. Тој дел од Македонија е познат како подрачје кое имало најдоцна вулканска активност на Балканскиот Полуостров. Но и покрај касната вулканска активност во поглед на флората претставува исклучително интересно подрачје поради богатството од ендемични и реликтни видови. На варовничката подлога или на подлога богата со арсен се развиваат еден покрај друг ендемите Viola allchariensis, Viola arsenica, Onobrychis degeni, Knautia caroli-rechingeri, Centaurea leucomala и Asyneuma cordifolia.

Во другите низински делови на Македонија на поедини места може да се најдат места на кои се развиваат по еден или два ендемити како на пример кај Дебар (Silene soskae и Sambucus deborensis), во околината на Битола (Gypsophylla macedonica и Aira scoparia), во околината на Радуша кај Скопје (Bromus oostachys и Carum seseloides) и др. (Micevski \& Matevski, 1987).

\section{IUCN црвена листа на загрозени видови}

IUCN (Interanational Union for Conservation Nature) е основана во октомври 1948 година како IUPN (International Union for the Protection of Nature) на меѓyнародна конференција во Франција. Организацијата го променила името во International Union for Conservation of Nature and Natural Resources во 1956 година (скратено IUCN или UICN на француски и шпански). Употребата на името World Conservation Union во релација со IUCN започнало во 1990 година. Претставува најстара и најголема еколошка организација во светот во која членуваат повеќе од 1000 владини и невладини организации и скоро 11000 научници волонтери во повеќе од 160 земји. Нејзината работа е поткрепена со повеќе од 1000 професионалци во 60 канцеларии низ светот и стотици партнери од невладини организации и приватниот сектор. Седиштето на организацијата е во Гланд, во близина на Женева во Швајцарија. Има и официјален статус на набљудувач во Генералното собрание на Обединетите нации.

Според оваа организација растенијата се означуваат со посебни ознаки се со цел да се овозможи полесна групација и заштита на видовите од изумирање. Како кратеници се користат следниве: Ex - extinct (истребен), En - endangered (загрозен), V - vulnerable (ранлив), R rare (редок) и I - undefined (недефиниран) (International Union for Conservation of Nature. www.iucn.org.).

\section{Значајни растителни подрачја (ЗРП)}

Главната цел на програмата за значајните растителни подрачја е да се идентификуваат и заштитат приоритетните области за растенијата низ цела Европа, користејќи сооодветни критериуми. Целите на програмата ги опфаќаат петте главни задачи на Европската стратегија за заштита на растенијата (Меловски и сор., 2010):

1. толкување и документирање на растителниот диверзитет (растителна разновидност),

2. заштита на растителниот диверзитет,

3. одржливо користење на растителниот диверзитет,

4. едукација на тема "Растителен диверзитет",

5. зајакнување на капацитетите за заштита на растителниот диверзитет.

\section{Потенцијани значајни растителни подрачја (ЗРП) во Македонија}

Според наведените критериуми во Македонија се издвоени 42 значајни растителни подрачја од кои $12 \mathrm{ce}$ наоѓаат на границите со соседните земји. Според критериумот А се класифицирани 40 ЗРП, а сите 42 се класифицирани според критериумот С. Загрозените ендемични видови (Aiii) се застапени во $62 \%$ од македонските ЗРП, а субендемитите (главно балкански енде- 

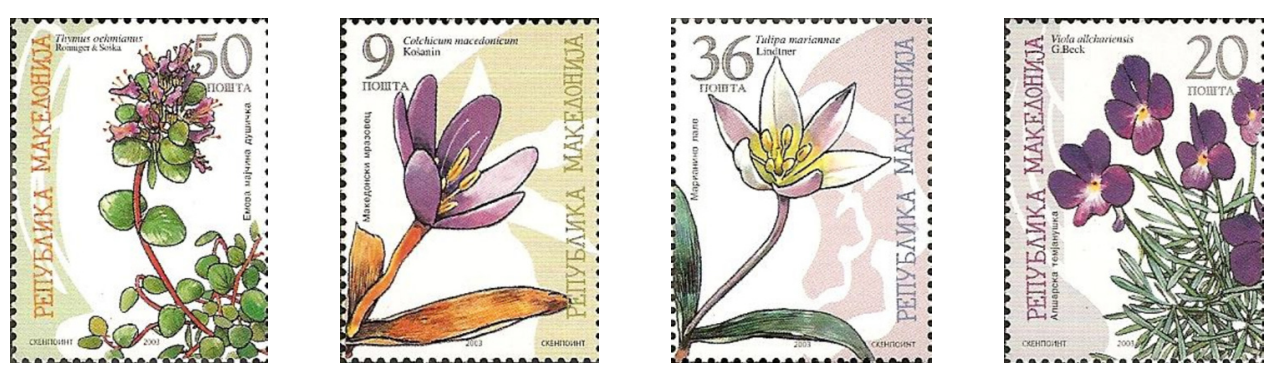

Слика 1. Некои од типичните македонски ендемити се искористени како филателистички орнаменти

Табела 3. Фармакогностички интересни ендемични растенија, со локалитети и класификацијата според IUCN (Meловски и сор., 2010)

\begin{tabular}{|c|c|c|c|}
\hline Вид & Фамилија & Локалитети & IUCN * \\
\hline Alchemilla pelisterica & Rosaceae & Пелистер & \\
\hline Alkanna nonneiformis & Boraginaceae & $\begin{array}{l}\text { Бабуна, Бистра, Галичица, Јакупица, Маврово, При- } \\
\text { леп, Скопска Црна Гора, Таорска клисура, Клисура на } \\
\text { река Треска, Водно, Шар Планина }\end{array}$ & $\mathrm{R}$ \\
\hline Armeria vandasii & Plumbaginaceae & Прилеп & $\mathrm{R}$ \\
\hline Asplenium macedonicum & Aspleniaceae & Мариово, Прилеп & \\
\hline Astragalus cernjavskii & Fabaceae & Криволак & \\
\hline Centaurea leucomalla & Asteraceae & Алшар-Трибор & \\
\hline Centaurea marmorea & Asteraceae & Прилеп & \\
\hline Centaurea rufidula & Asteraceae & Дојранско Езеро & $\mathrm{R}$ \\
\hline Dianthus kapinensis & Caryophyllaceae & Македонски Брод-Барбарас, Клисура на река Треска & \\
\hline Gypsophila macedonica & Caryophyllaceae & & $\mathrm{R}$ \\
\hline Hedysarum macedonicum & Fabaceae & Криволак, Овче Поле-Богословец & $\mathrm{R}$ \\
\hline Heptaptera macedonica & Apiaceae & Демиркаписка клисура, Клисура Раец -Тиквешко Езеро & I \\
\hline Knautia caroli-rechingeri & Dipsacaceae & Алшар-Трибор & \\
\hline Moehringia minutiflora & Caryophyllaceae & Јакупица, Мариово, Прилеп & $\mathrm{R}$ \\
\hline Nepeta ernesti-mayeri & Lamiaceae & Галичица & \\
\hline Onobrychis degenii & Fabaceae & Алшар-Трибор & I \\
\hline Pedicularis ferdinandii & Orobanchaceae & Јакупица & $\mathrm{R}$ \\
\hline $\begin{array}{l}\text { Salvia jurisicii } \\
\text { Sambucus deborensis }\end{array}$ & $\begin{array}{l}\text { Lamiaceae } \\
\text { Adoxaceae }\end{array}$ & $\begin{array}{l}\text { Криволак, Овче Поле-Богословец } \\
\text { Дебар }\end{array}$ & $\mathrm{R}$ \\
\hline Saxifraga karadzicensis & Saxifragaceae & Јакупица & \\
\hline Sempervivum octopodes & Crassulaceae & Ниџе, Пелистер & $\mathrm{R}$ \\
\hline $\begin{array}{l}\text { Sempervivum thopso- } \\
\text { nianum }\end{array}$ & Crassulaceae & Стогово & $\mathrm{R}$ \\
\hline Silene paeoniensis & Caryophyllaceae & Бабуна, Мариово & \\
\hline Silene schmucheri & Caryophyllaceae & Кораб-Дешат, Шар Планина & $\mathrm{R}$ \\
\hline $\begin{array}{l}\text { Silene viscariopsis } \\
\text { Thymus alsarensis }\end{array}$ & $\begin{array}{l}\text { Caryophyllaceae } \\
\text { Lamiaceae }\end{array}$ & $\begin{array}{l}\text { Бабуна, Мариово, Прилеп } \\
\text { Алшар-Трибор }\end{array}$ & $\mathrm{R}$ \\
\hline $\begin{array}{l}\text { Thymus skopjensis } \\
\text { Thymus oehmianus }\end{array}$ & $\begin{array}{l}\text { Lamiaceae } \\
\text { Lamiaceae }\end{array}$ & Клисура на река Треска & Ex \\
\hline Tulipa marianae & Liliaceae & Криволак & \\
\hline Tulipa scardica & Liliaceae & Радуша-Жеден & \\
\hline Verbascum herzogii & Scrophulariaceae & Клисура Раец-Тиквешко езеро, Мариово & $\mathrm{R}$ \\
\hline Verbascum macedonicum & Scrophulariaceae & Демиркаписка Клисура, Клисура Раец-Тиквешко Езеро & $\mathrm{R}$ \\
\hline Viola allchariensis & Violaceae & Алшар-Трибор & \\
\hline Viola arsenica & Violaceae & Алшар-Трибор & \\
\hline
\end{tabular}

* Глобална црвена листа 
Табела 4. Фармакогностички интересни ендемични видови во флората на Р. Македонија во споредба со компаративни видови од истиот род за кои се објавени релевантни фармакогностички податоци

\begin{tabular}{|c|c|c|c|}
\hline Бр. & Ендемски вид & $\begin{array}{c}\text { Компаративен вид од } \\
\text { истиот род }\end{array}$ & Фармакогностички значајни податоци на компаративниот вид \\
\hline 1. & $\begin{array}{l}\text { Alchemilla } \\
\text { pelisterica } \text { Pawl., } \\
\text { Rosaceae }\end{array}$ & Alchemilla vulgaris L. & $\begin{array}{l}\text { Херба: танини (елагни танини), флавоноиди (кверцетин), салицилна } \\
\text { киселина во траги и др. } \\
\text { Дејство: атстрингентно, антиинфламаторно, диуретично, } \\
\text { антидијароично (Kiselova et al., 2006). }\end{array}$ \\
\hline 2. & $\begin{array}{l}\text { Alkanna } \\
\text { nonneiformis } \\
\text { Griseb., } \\
\text { Boraginaceae }\end{array}$ & Alkanna tinctoria L. & $\begin{array}{l}\text { Корен: црвени пигменти од 5-6 \% алканин и негови естри и } \\
\text { пиролизидински алкалоиди. } \\
\text { Дејство: атстрингентно, антидијароично, } \\
\text { (Assimopoulou \& Papageorgiou, 2005). }\end{array}$ \\
\hline 3. & $\begin{array}{l}\text { Armeria } \\
\text { vandasii Hayek, } \\
\text { Plumbaginaceae }\end{array}$ & $\begin{array}{l}\text { Armeria martima } \\
\text { (Mill.) Willd. }\end{array}$ & $\begin{array}{l}\text { Корен: хинони - плумбагин, алкалоиди, антоцијанидини и др. } \\
\text { Дејство: антиоксидатнтно, потенцијално цитотоксично. Способност } \\
\text { за акумуласција на метали од надворешна средина. (Allen \& Hatfield, } \\
\text { 2004; Szarek-Łukaszewska et. al., 2004). }\end{array}$ \\
\hline 4. & $\begin{array}{l}\text { Asplenium } \\
\text { macedonica } \\
\text { Asplenidaceae }\end{array}$ & Asplenium trichomanes & $\begin{array}{l}\text { Херба: токоферол, холестерол, ситостерол и стигмастерол, киселини, } \\
\text { флавоноиди и др. } \\
\text { Дејство: експекторанс, еменагог и лаксативн. }\end{array}$ \\
\hline 5. & $\begin{array}{l}\text { Astragalus } \\
\text { cernjavskii Stoj., } \\
\text { Fabaceae }\end{array}$ & $\begin{array}{l}\text { Astragalus } \\
\text { membranaceus (Fisch. } \\
\text { Ex Link.) Bunge. }\end{array}$ & $\begin{array}{l}\text { Корен: полисахариди, алкалоиди, холин, бетаин, гума, тритерпеноидни } \\
\text { сапонини, амино киселини и др. } \\
\text { Дејство: адаптогено, антиоксиданто, антиинфламаторно и } \\
\text { антибактериско, антивирусно, имуномодулаторно и др. (Matkowski et } \\
\text { al., 2003; Zheng et al., 1998). }\end{array}$ \\
\hline 6. & $\begin{array}{l}\text { Centaurea } \\
\text { leucomalla Bornm., }\end{array}$ & Centaurea cyanus L. & \\
\hline & $\begin{array}{l}\text { Centaurea } \\
\text { marmorea } \text { Bornm.\& } \\
\text { Soska, }\end{array}$ & & $\begin{array}{l}\text { Цвет: флавоноиди и антоцијани, танини, кумарини, слузи и др. } \\
\text { Дејство: намалува инфекции на очите, дејствува антиинфламаторно } \\
\text { дејство и спречува создавање каменчиња во уринарниот тракт. Има и } \\
\text { еменагогно, антиинфламаторно, аперитивно и тонизирачко дејство,а } \\
\text { се користи при габични инфекции, треска, кашлица, констипација, } \\
\text { нарушувања во функцијата на црниот дроб и жолчката и други состојби } \\
\text { (Takeda \& Tominaga, 1983; Garbacki et al., 1999). }\end{array}$ \\
\hline
\end{tabular}

Dianthus superbus

Gypsophila paniculata L.

8. Gypsophila macedonica Vandas., Caryophyllaceae

9. Hedysarum macedonicum Bornm., Fabaceae

10. Heptaptera macedonica Bornm., Apiaceae

11. Knautia carolirechingeri Micev., Dipsacaceae

12. Nepeta ernestimayeri Dikl. et Nikolic, Lamiaceae
Nepeta cataria L.
Hedysarum polybotrys

Heptaptera sp.

Knautia arvensis $\mathrm{L}$.
Херба: антоцијанини, емодин, естри на бензоева киселина, ситостерол-3О-глукозид, емодин-8-О-гликозид, изоориентин, фицион, тритерпенски сапонини и др. Дејство: диуретично (Li et al., 2000).

Корен: сапонини.

Дејство: експекторант, спермицид (Primorac et al., 1985; Southon et al., 1998).

Корен: танини, флавоноиди, сапонини, протеини и јаглехидрати (Hai et al., 2004; Piccaglia et al., 2003).

Дејство: антиоксидативно (Chen et al., 2007; Hailiqian et al., 2007).

Херба/плод: етерично масло (Yilmaz et al., 2009).

Дејство: антиоксидантно и на ацетилхолин естераза.

Херба/цвет: тритерпенски сапонини, иридоиди, стероиди, флавоноиди, танини и др. (Kowalczyk, 1996).

Дејство: Атстрингентно, антисептично, експекторантно и благо диуретично (Hoffmann et al., 2008).

Херба: етерично масло со карвакрол, непетол, тимол, напеталактон, цитронелол и гераниол; потоа витамини $\mathrm{C}$ и Е, танини и розмаринска киселина (Kimek \& Modnicki, 2005).

Дејство: карминативно, дијафоретско, еменагогно и афродизијачко, антиоксидантно (Adiguzel et al., 2009; Sarkar et al., 2005). 


\begin{tabular}{ccc}
\hline \hline Бр. & Ендемски вид & $\begin{array}{c}\text { Компаративен вид од } \\
\text { истиот род }\end{array}$ \\
\hline 13. & $\begin{array}{l}\text { Onobrychis degenii } \\
\text { Dörfl., Fabaceae }\end{array}$ & Onobrychis vicifolia
\end{tabular}

Фармакогностички значајни податоци на компаративниот вид

Dörfl., Fabaceae

Лист: арбутин, кемпферол, кверцетин, рутин, никотилфлорин, танини (катехин, епикатехин, галокатехин и епигалокатехин), процијанидин и проделфинидин. (Marais et al., 2000). Фитоестрогени компоненти (Halabalaki et al., 2006).

14. Pedicularis ferdinandii Bornm., Orobanchaceae

15. Salvia jurisicii Kosanin, Lamiaceae

16. Saxifraga karadzicensis (Deg. et Kos.) Bornm., Saxifragaceae

17. Sempervivum octopodes Turill

Sempervivum thopsonianum Wale.

18. Silene paeoniensis Bornm., Silene schmucheri Boiss., Silene viscariopsis Bornm.,

19. Thymus alsarensis Ronn.

Thymus oehmianus Ronn. \& Soska,

20. Lamiaceae Tulipa marianae Lindtn.

Tulipa scardica Bornm., Liliaceae

21. Verbascum herzogii Bornm.

Verbascum macedonicum Kosanin \& Murb.,

22. Viola allchariensis Beck

Silene viridiflora Silene capensis Caryophyllaceae

Sempervivum tectorum L.,

\section{Crassulaceae}

Thymus vulgaris L.

Tulipa sp.

(T. gesneriana)

(T. sintenisii)

Verbascum thapsus L.

Scrophulariaceae

Viola arsenica Beck, Violaceae
Дејство: естрогено.

Херба: фенилпропаноидни и иридоидни гликозиди, алкалоиди, танини (Kang \& Jia, 1997).

Дејство: антиоксидантно, седативно, хипотензивното и холеретичното $(* 1)$.

Лист: етерично масло со тујон, цинеол, борнеол, линалол, камфор, салвен и пинен; естрогени супстанции, салвин и карнозинска киселина, флавоноиди, фенолни киселини, розмаринска киселина, танини и др.

Дејство: антибактериско, антифунгално, антиоксидантно, аналгетично, ароматично, антиперспирантно, атстрингентно дејство (Baricevic et al., 2001; Pizzale et al., 2002).

Корен: танини, гална киселина, скроб, глукоза, минерали, албумин, слузни материи и др.

Дејство: антиинфламаторно и атстрингентното дејство, експекторантно, уроантисептично $(* 2)$.

Лист: полифеноли (кемпферол е единствен агликон), делфинидол (единствен антоцијанидин), 4-тиобензил-(-)-епигалокатехин, 4-тиобензил (-) епигалокатехин-3-галат, слузни материи, смолести материи и др. (Abram \& Donko, 1999).

Дејство: Атстрингентно, антимикробно антивирално (Blázovics et al., 2003; Šentjurc et al., 2003).

Лист/семе: сапонини, ситостерол, стигмастерол, полиизопреноиди, $\alpha$-токоферол, есенцијални амино киселини (хистидин, изолеуцин, леуцин, лизин, фенилаланин, метионин, треонин, валин и аргинин), галактоза, глукоза, арабиноза и рамноза, пектински материи и др. (Eshmirzaeva et al., 2005).

Дејство: емолиентно, смирувачко, седативно.

Херба: етерично масло со карвакрол и тимол, флавоноидни гликозиди, фенолни компоненти и полисахариди.

T. alsarensis: етерично масло (Kulevanova et al., 1996a,b).

Дејство: антимикробно, антиоксидативно, сапазмолитично (Marino et al., 1999; Meister et al., 1999).

Цвет: антоцијанини (Novruzov \& Ibadov, 1986).

Дејство: антимикробно (Fujimura et al., 2004).

Цвет: слузи, гуми, тарги од етерични масла, смоли, сапонини, фалавоноиди, аукубин и други иридоиди, стероли, каротеноиди, ксантофили и танини (Warashina et al., 1992; Klimek, 1996; Pardo et al., 1998).

Дејство: експекторантно, антимикробно, благо диуретично, лаксативно, емолиентно и благо седативно (Tatli \& Akdemir, 2006).

Херба/цвет: салицилна киселина и нејзини деривати (метил естри и гликозиди), флавоноиди (виолантин и рутин), сапонини, алкалоиди, танини, слузи, гуми и смоли (Toiu et al., 2009; Vukics et al., 2008a; Molnár \& Szabolcs, 1980).

Дејство: експекторантно, антиинфламаторно, диуретично, антиревматско и лаксативно (Witkowska-Banaszczak et al., 2005; Toiu et al., 2007; Vukics et al., 2008b; Rimkieni et al., 2003).

* цитатот се однесува на соодветен web-cite:

1 - Lousewort (Pedicularis muscicola). http://www.martindalesnutrition.com/ns/DisplayMonograph.asp?StoreID=le1jvdg81es92lh70g03n0et9d9x0r89\&D ocID=bottomline-lousewort.;

2 - Saxifraga granulata. http://www.ayurveda-textbooks.com/saxifraga-granulata.html; 
Табела 5. Фармакогностички интересни субендемични растенија според локалитети и класификацијата според IUCN (Меловски и сор., 2010)

\begin{tabular}{|c|c|c|c|}
\hline Вид & Фамилија & Локалитет & IUCN * \\
\hline $\begin{array}{l}\text { Acer heldreichii subsp. } \\
\text { visiani }\end{array}$ & Sapindaceae & Бистра; Шар Планина & I \\
\hline Ajuga piskoi & Lamiaceae & Галичица & $\mathrm{R}$ \\
\hline Alkanna stribrnyi & Boraginaceae & $\begin{array}{l}\text { Дојранско Езеро; катланово-Бадер; Клисура Раец-Тиквешко } \\
\text { Езеро; Скопска Црна Гора; Таорска клисура; Клисура на } \\
\text { река Тополка }\end{array}$ & $\mathrm{R}$ \\
\hline Alyssum doerfleri & Brassicaceae & Клисура Раец-Тиквешко езеро; Мариово; Прилеп & $\mathrm{R}$ \\
\hline Anchusa macedonica & Boraginaceae & $\begin{array}{l}\text { Катланово-Бадер; Криволак; Овче Поле-Богословец; } \\
\text { Прилеп; Таорска клисура; Клисура на река Тополка }\end{array}$ & \\
\hline Anchusa serpentinicola & Boraginaceae & Галичица; Прилеп & $\mathrm{R}$ \\
\hline Anthemis meteorica & Asteraceae & Демиркаписка Клисура; Дојранско Езеро & $\mathrm{R}$ \\
\hline Astragalus baldacii & Fabaceae & Галичица; Радуша-Жеден & $\mathrm{R}$ \\
\hline Astragalus physocalyx & Fabaceae & Богданци (Чурчулум-Паљурци) & $\mathrm{Ex} / \mathrm{En}$ \\
\hline Aubrieta thessalia & Brassicaceae & Јабланица & $\mathrm{R}$ \\
\hline Campanula debarensis & Campanulaceae & Клисура на Црн Дрим (Глобочица-Луково-Дебар) & \\
\hline Centaurea grbavacensis & Asteraceae & $\begin{array}{l}\text { Баба Сач-Љубен; Буковиќ-Стража; Јакупица; Клисура Раец- } \\
\text { Тиквешко Езеро; Македонски Брод-Барбарас;Мариово; } \\
\text { Прилеп; Сува Гора; Клисура на река Треска }\end{array}$ & $\mathrm{R}$ \\
\hline Centaurea kosaninii & Asteraceae & Радуша-Жеден & $\mathrm{R}$ \\
\hline Centaurea soskae & Asteraceae & Галичица & $\mathrm{R}$ \\
\hline Colchicum macedonicum & Colchicaceae & Јакупица & $\mathrm{R}$ \\
\hline Colchicum pieperanum & Colchicaceae & Бистра & $\mathrm{R}$ \\
\hline Cynoglossum scardicum & Boraginaceae & Бистра; Галичица; Маврово & $\mathrm{R}$ \\
\hline Dianthus myrtinervius & Caryophyllaceae & Пелистер & $\mathrm{R}$ \\
\hline Dianthus scardicus & Caryophyllaceae & Шар Планина & \\
\hline Erodium guicciardii & Geraniaceae & $\begin{array}{l}\text { Баба Сач-Љубен; Буковиќ-Стража; Галичица; Македонски } \\
\text { Брод-Барбарас }\end{array}$ & $\mathrm{R}$ \\
\hline Eryngium serbicum & Apiaceae & Алшар-Трибор; Галичица; Маврово; Прилеп; Шар Планина & $\mathrm{R}$ \\
\hline Fritillaria graeca & Liliaceae & $\begin{array}{l}\text { Плачковица; Прилеп; Скопска Црна Гора; Таорска клисура; } \\
\text { Клисура на река Треска; Водно }\end{array}$ & \\
\hline Fritillaria gussichiae & Liliaceae & $\begin{array}{l}\text { Бабуна-кањонскиот дел; Кожуф-Дудица; Осогово; Клисура } \\
\text { на река Треска }\end{array}$ & $\mathrm{R}$ \\
\hline Fritillaria macedonica & Liliaceae & Јабланица; Кораб-Дешат & $\mathrm{R}$ \\
\hline Galium rhodopeum & Rubiaceae & Криволак; Овче Поле-Богословец; Клисура на река Треска & \\
\hline Genista nissana & Fabaceae & $\begin{array}{l}\text { Јакупица; Радуша-Жеден; Скопска Црна Гора; Клисура на } \\
\text { река Треска; Водно }\end{array}$ & $\mathrm{R}$ \\
\hline Hypericum dimoniei & Hypericaceae & Кожуф-Дудуца; Беласица & \\
\hline Isoetes phrygia & Isoetaceae & $\begin{array}{l}\text { Богданци (Чурчулум-Паљурци); Мариово; Струмица- } \\
\text { Моноспитовско Блато }\end{array}$ & \\
\hline Jurinea taygetea & Asteraceae & Галичица & $\mathrm{R}$ \\
\hline
\end{tabular}




\begin{tabular}{|c|c|c|c|}
\hline Вид & Фамилија & Локалитет & IUCN * \\
\hline Lilium albanicum & Liliaceae & $\begin{array}{l}\text { Беласица; Бистра; Галичица; Јабланица; Јакупица; Кожуф- } \\
\text { Дудица; Кораб-Дешат; Ниџе; Шар Планина; Пелистер }\end{array}$ & \\
\hline Linum elegans & Linaceae & Мариово & $\mathrm{R}$ \\
\hline $\begin{array}{l}\text { Melampyrum } \\
\text { heracleoticum }\end{array}$ & Orobanchaceae & $\begin{array}{l}\text { Клисура на Црн Дрим; Галичица; Јакупица: Клисура на река } \\
\text { Треска; Мариово }\end{array}$ & $\mathrm{R}$ \\
\hline Minuartia baldaccii & Caryophyllaceae & Јабланица & $\mathrm{R}$ \\
\hline Narthecium scardicum & Nartheciaceae & Јабланица; Јакупица; Кораб-Дешат; Шар Планина & $\mathrm{R}$ \\
\hline Oxytropis purpurea & Fabaceae & Бистра; Галичица; Илинска Планина & $\mathrm{R}$ \\
\hline Pedicularis limnogena & Orobanchaceae & Пелистер & $\mathrm{R}$ \\
\hline Pinus peuce & Pinaceae & Јабланица; Ниџе; Пелистер; Шар Планина & $\mathrm{R}$ \\
\hline Potentilla doerfleri & Rosaceae & Шар Планина & $\mathrm{R}$ \\
\hline Potentilla visanii & Rosaceae & Радуша-Жеден & $\mathrm{R}$ \\
\hline Ramonda nathaliae & Gesneriaceae & $\begin{array}{l}\text { Клисура Раец-Тиквешко езеро; Кожуф-Дудица; Мариово; } \\
\text { Ниџе; Скопска Црна Гора; Таорска клисура; Клисура на } \\
\text { река Треска; Шар Планина }\end{array}$ & $\mathrm{R}$ \\
\hline Ramonda serbica & Gesneriaceae & $\begin{array}{l}\text { Бистра; Клисура на Црн Дрим; Галичица; Маврово; Шар } \\
\text { Планина }\end{array}$ & $\mathrm{R}$ \\
\hline Ranunculus cacuminis & Ranunculaceae & Ниџе & $\mathrm{V}$ \\
\hline Ranunculus degenii & Ranunculaceae & Кораб-Дешат; Шар Планина & $\mathrm{Ex} / \mathrm{En}$ \\
\hline $\begin{array}{l}\text { Ranunculus wettsteinii } \\
\text { Rhamnus }\end{array}$ & Ranunculaceae & Кораб-Дешат & \\
\hline Rindera graeca & Boraginaceae & & $\mathrm{R}$ \\
\hline Sempervivum kindingeri & Crassulaceae & Таорска Клисура & $\mathrm{R}$ \\
\hline Sempervivum kosaninii & Crassulaceae & Бистра; Кораб-Дешат; Шар Планина & $\mathrm{R}$ \\
\hline $\begin{array}{l}\text { Sempervivum } \\
\text { macedonicum }\end{array}$ & Crassulaceae & Јакупица & $\mathrm{R}$ \\
\hline Sideritis raeseri & Lamiaceae & Галичица; Мариово & \\
\hline Sideritis scardica & Lamiaceae & $\begin{array}{l}\text { Баба Сач-Љубен; Бистра; Илинска Планина; Клисура на } \\
\text { река Треска; Шар Планина }\end{array}$ & \\
\hline Soldanella pindicola & Primulaceae & Јакупица; Кораб-Дешат; Пелистер; Шар Планина & $\mathrm{R}$ \\
\hline Stipa rechingeri & Poaceae & Мариово & $\mathrm{R}$ \\
\hline Trifolium pilczii & Fabaceae & $\begin{array}{l}\text { Бабуна-кањонскиот дел; Бистра; Галичица; Јабланица; } \\
\text { Пелистер; Стогово }\end{array}$ & \\
\hline Viola brachyphylla & Violaceae & Ниџе & $\mathrm{R}$ \\
\hline Viola eximia & Violaceae & Галичица; Јабланица; Кожуф-Дудица; Ниџе; Пелистер & $\mathrm{R}$ \\
\hline Viola kosaninii & Violaceae & Бабуна-кањонскиот дел; Сува Гора & $\mathrm{R}$ \\
\hline Viola stojanowii & Violaceae & Беласица & $\mathrm{R}$ \\
\hline
\end{tabular}

* Глобална црвена листа 
мити) (Aiv) во 90,4\% од подрачјата. Значајно е и тоа што македонските ЗРП содржат само 6 видови од списоците на Европската директива за живеалишта и само 4 кои се на Глобалната Црвена листа со што се укажува на несоодветност на овие листи за употреба во Југоисточна Европа. Листите на Бернската конвенција кои се паневропски се посоодветни за примена во овој регион. Најчесто се застапени шумите и пасиштата како ЗРП (85\% и 67\% соодветно) и тоа најчесто на 18 планински масиви. Најчести се широколисните листопадни шуми во 34 ЗРП и широколисните зимзелени шуми во 23 ЗРП. Иглолисни шуми се застапени во 9 ЗРП. Од пасиштата најзастапени се сувите брдски пасишта во 20 ЗРП, а потоа планинските и високопланинските пасишта во 12 ЗРП. Чести се и живеалиштата со слаб вегетациски покрив (околу 60\% од сите ЗРП). Тука најчесто спаѓаат карпи и карпести предели во 25 ЗРП од кои 8 се длабоки речни клисури и кањони, но овде се вклучени и планински карпи.

\section{Фармакогностички интересни ендемични видови во флората на Р. Македонија}

Според определени податоци, 10\% од светската флора се растенија што се декларираат како лековити, ароматични и медицински или фармацветски значајни, било како лековити (Metha, Matricaria, Digitalis, Hypericum, ....), било како извори на екстракција и изолација на фармаколошки активни (таксол, подофилотоксин, винбластин, рутин, ....) или индиферентни супстации за употреба во фармацевтска технологија (скроб, целулоза, растителни масла, арапска гума, ....). Растенијата во медицината, во фармацијата и во козметиката имаат големо значење, но нивнато комерцијално значење и употреба во производство на храна, пијалоци, производи од тутун, емулгатори во различни области, средства за флотација на руди, материјали за гаснење пожари, и редица други намени ги прави особено интересни за различни испитувања.

Од фармакогностичкиот аспект, проучувањето на до сега неиспитаните растителни видови во поглед на нивниот хемиски состав и евентуална биолошка и фармаколошка активност, значи многу повеќе отколку само надополнување на вкупниот научен фонд на информации за растителните суровини. Проучувањето на ендемичните видови од Р. Македонија, во оваа смисла се особено значајни токму заради нивната уникатност и релативна недостапност за истражувачи од странство, што за домашните научни работници од националните институции претставува дополнителен предизвик. Ендемичните видови се предизвик токму поради тоа што до сега фармакогностички воопшто не биле проучувани.

Од 135 ендемични видови вкупно во флората на P. Македонија, сепак не сите веднаш го привлекуваат нашето внимание. Во однос на изборот на ендемитите кои евентуално би се проучувале, во Табела 3 се наведени оние што се фармакогностички интересни. Во Табела 4 се прикажани истите таксони во споредба со избрани компаративни видови кои се до сега фармакогностички испитувани, при што се дадени податоци за основниот хемиски состав и за најзначајните биолошко-фармаколошки дејства на компаративните видови.

За одбележување е фактот дека во флората на Р. Македонија се јавува и голем број суб-ендемични видови. Во Табела 5 се дадени оние што се потенцијално фармакогностички интересни. Речиси ниту еден од наведените видови не е фармакогностички проучуван од научни работници од домашните институции.

Од сите наведени субендемични видови во Р. Македонија, само видовите Sideritis raeseri и Sideritis scardica се изучувани во поглед на хемискиот состав и биолошката активност. Во однос на хемискиот состав, определен е составот на етеричното масло (Kostadinova et al, 2007), составот на хексанските екстракти (Kostadinova et al., 2008) и идентификувани се и определени флавоноидните агликони (Janeska et al., 2007). Во однос на биолошката активност испитувана е антимикробната на хексанските екстракти (Kostadinova et al., 2008), при што е утврдена добра активност врз Staphylococcus aureus.

\section{Заклучок}

Се проценува дека вишите растенија во флората во Република Македонија опфаќаат околу 3200 видови во 147 фамилии. Од нив посебно се значајни ендемичните растенија, кои успеале да се развијат на овој дел на Балканскиот Полуостров врз основа на геолошкото минато. Според некои извори има 115 познати ендемични виши растенија од кои 114 припаѓаат во групата скриеносемени. Во класата дикотиледони има 109 ендемични видови, а во класата на монокотиледони има само 5 видови. Фамилии со најмногу ендемични видови се: Asteraceae (18), Caryophyllaceae (17), Lamiaceae (12), Violaceae (10), Scrophulariaceae (9) и Rosaceae (9). Според други извори има 135 видови ендемични растенија од кои се смета дека околу 111 се локални ендемични видови, а 24 во пограничните планини. Точниот број сеуште не може да се утврди. Источниот дел на Македонија, источно од реката Вардар скоро и да нема ендемити, додека останатата територија западно од Вардар е многу богата со вакви видови. Од планините најбогата е Галичица, од клисурите - клисурата на реката Треска, а од низините посебно се истакнува околината на Прилеп.

Значајно е што и покрај богатството на ендемични и реликтни видови сеуште нема податоци за нивниот хемиски состав, евентуалното дејство и можната употреба. Од наведените ендемични видови околу 30 би биле фармакогностички интересни за испитување на хемискиот состав, изолација на потенцијално активни 
супстанции и испитување на биолошко-фармаколошка активност. Секако дека новите инструментални техники што денес се користат во хемијата на медицинските растенија и хемијата на природните производи овозможуваат користење на минимално количество материјал, што не претставува ризик за природните популации на ендемичните видови. Во поглед на биолошко-фармаколошката анализа, bio-assay водените техники би овозможиле рационално користење на екстрактите и изолатите од интерес, со што исто така би се намалила потреба од собирање поголемо количество материјал. Дополнителен предизвик претставува секако планирање на соодветна програма за заштита на сите ендемични растенија без оглед на степеност на нивната загрозеност, со особен акцент на видовите што се фармакогностички интересни и што покажале позитивни резултати во фармакогностичката анализа.

\section{Литература}

Abram, V., Donko, M., 1999. Tentative Identification of Polyphenols in Sempervivum tectorum and Assessment of the Antimicrobial Activity of Sempervivum L., Journal of Agricultural and Food Chemistry 47 (2), 485-489.

Adiguzel, A., Ozer, H., Sokmen, M., Gulluce, M., Sokmen, A., Kilic, H., Sahin, F., Baris, O., 2009. Antimicrobial and antioxidant activity of the essential oil and methanol extract of Nepeta cataria, Polish J. Microbio. 58 (1), 69-76. Available at: http://jonnsaromatherapy.com/pdf/GC-MS Nepeta_cataria_2009_01.pdf

Allen, D.E., Hatfield, G., 2004. Medicinal plants in folk traditions: an ethnobotany of Britain \& Ireland, Portland, OR, and Cambridge: Timber Press, pp.100. Available at: http://books. google.com/books?id=4oK04rRw-k4C\&pg=PA100\&lpg=P A100\&dq $=$ armeria + official + drug + medicinal \&source=bl\&o ts=Wzx_R-D8DL\&sig=xsiQ3uvO2K2gz1BsHq0Q_NTY-J $8 \& \mathrm{hl}=\mathrm{en}_{-} \& \mathrm{ei}=65 \mathrm{qx}$ TaHqJoT3 $\mathrm{sgbNuv} 3 \mathrm{CW} \& \mathrm{sa}=\mathrm{X} \&$ oi $=$ boo $\mathrm{k} \_$result\&ct $=$result\&resnum $=1 \& \mathrm{ved}=0 \mathrm{CBQQ6AEwAA \# v=}$ onepage \&q\&f=false

Assessment and evaluation of biodiversity on national level (Report and national catalogue of species). Available at: http:// www.undp.org.mk/content/Publications/Biodiverzitet $\% 20$ eng(6).pdf

Assimopoulou, A.N,, Papageorgiou, V.P. 2005. Radical scavenging activity of Alkanna tinctoria root extracts and their main constituents, hydroxynaphthoquinones, Phytother Res. 19(2), 141-147.

Baricevic, D., Sosa, S., Della Loggia, R., Tubaro, A., Simonovska, B., Krasna, A., Zupancic, A., 2001. Topical anti-inflammatory activity of Salvia officinalis L. leaves: the relevance of ursolic acid, J. Ethnopharmacol. 75 (2-3), 125-132.

Biodiversity. Available at: http://www.catsg.org/balkanlynx/05 wildlife-management/5_4_biodiversity/Pdfs/GRIDA _2000_Biodiversity_in_FYR_Macedonia.pdf

Blázovics, A., Lugasi, A., Szentmihályi, K., Kéry, A. 2003 Reducing power of the natural polyphenols of Sempervivum tectorum in vitro and in vivo, Acta Biologica Szegediensis 47(1-4):99-102. http://www.sci.u-szeged.hu/ABS

Chen, C., Donq, J.Y., Liu, K., Liu, Y.Q., Wanq, Y.L., 2007. Antioxidant effect of total flavonoids of Hedysarum polybotry on human umbilical vein endothelial cells injury induced by hydrogen peroxide, Zhong Yao Cai. 30 (9),1099102. http://www.ncbi.nlm.nih.gov/pubmed/18236754

Definition of endemic in US English dictionary, 2009. Oxford University Press. Available at: http://oxforddictionaries. com/definition/english/endemic

Endemic Plants. Available at: http://www.parks.tas.gov.au/file. aspx?id $=6504$

Endemic, eLook Online Dictionary. Available at: http://www. elook.org/dictionary/endemic.html

Endemism. 2009. Available at: http://en.wikipedia.org/wiki/ Endemism

Eshmirzaeva, N.E., Khidyrova, N.K., Khodzhaeva, M., Mezhlumyan, L.G., Shakhidoyatov, Kh. M., 2005. Chemical composition of Silene viridiflora, Chemistry of Natural Compounds 41 (4), 451. Available at: http://resources. metapress.com/pdf-preview.axd?code $=$ p10673027707m627 $\&$ size $=$ largestess

Fujimura, M., Ideguch, M., Minami, Y., Watanabe, K., Tadera, K., 2004. Purification, characterization, and sequencing of novel antimicrobial peptides, Tu-AMP 1 and Tu-AMP 2, from bulbs of tulip (Tulipa gesneriana L.), Biosci Biotechnol Biochem. 68(3), 571-7.

Garbacki, N., Gloaguen, V., Damas, J., Bodart, P., Tits, M., Angenot, L., 1999. Anti-inflammatory and immunological effects of Centaurea cyanus flower-heads, J Ethnopharmacol. 68(1-3), 235-41.

Habel, J.K., Assmann, T., Relict Species: Phylogeography and Conservation Biology, Springer, Heidelberg. Available at: http://books.google.com/books?id=vM TCbd_7qWUC\&pg $=$ PA3\&lpg $=$ PA3\&dq $=$ relict + plants + definition \& source $=$ bl\&ots $=$ QaaFBKo812\&sig $=$ ENW4y5SB1sY-SeOe5i5OTEE-mk\&hl=en\&ei=19mlTeHMo7AswbV1rmUCA\&sa $=X \&$ oi $=$ book_result\&ct $=$ resul t\&resnum $=6 \& \mathrm{ved}=0 \mathrm{CDwQ} 6 \mathrm{AEwBQ} \# \mathrm{v}=$ onepage $\& \mathrm{q}=$ relic $\mathrm{t} \%$ 20plants\%20definition\& $\mathrm{f}=$ false)

Hai, L.Q., Zhang, Q.Y., Liang, H., Zhao, Y.Y., Du, N.S., 2004. Studies on chemical constituents of Hedysarum polybotrys, Zhongguo Zhong Yao Za Zhi., 38(8), 592-5. http://www. ncbi.nlm.nih.gov/pubmed/15706896

Hailiqian, T., Kanq, J.S., Sun, L. 2007. Effects of aqueous extract of Hedysarum austrosibiricum on metabolism of oxyen free radicals in subacute aging mice caused by D-galactose, Zhongguo Zhong Yao Za Zhi. 32(8), 729-31. http://www. ncbi.nlm.nih.gov/pubmed/17608232

Halabalaki, M.,Alexi, X., Aligiannis, N., Lambrinidis, G., Pratsinis, H., Florentin, I., Mitakou, S., Mikros, E., Skaltsounis, A.L., Alexis M.N., 2006. Estrogenic activity of isoflavonoids from Onobrychis ebenoides, Planta Med. 72(6),488-93. http:// www.ncbi.nlm.nih.gov/pubmed/16773531

Hoffmann, E.M., Selje-Assmann, N., Becker, K., 2008. Dose studies on anti-proteolytic effects of a methanol extract from Knautia arvensis on in vitro ruminal fermentation, Animal Feed Science and Techology 145 (1), 285-301. http://www.ncbi.nlm.nih.gov/pubmed/3345304

International Union for Conservation of Nature. Available at: http://www.iucn.org/about/

Janeska, B., Stefova, M., Alipieva, K., 2007. Assay of flavonoid aglycones from the species of genus Sideritis (Lamiaceae) from Macedonia with HPLC-UV DAD, Acta Pharm., 57(3), 371-377.

Kang, J., Jia, Z. 1997. The Chemical Constituents of Pedicularis muscicola Maxim., Zhongguo Zhong Yao Za Zhi., 22(3): 
167-8, 191-2. (abstract). http://www.ncbi.nlm.nih.gov/ pubmed/10743186

Kimek, B., Modnicki, D., 2005. Terpenoids and sterols from Nepeta cataria L. var. citriodora (Lamiaceae), Acta Poloniae Pharmaceutica, Drug Research 62(3):231-5. Available at: http://www.ptfarm.pl/pub/File/Acta_Poloniae/2005/3/231235.pdf

Kiselova, Y., Ivanova, D., Chervenkov, T., Gerova, D., Galunska, B., Yankova, T., 2006. Correlation between the in vitro antioxidant activity and polyphenol content of aqueous extracts from Bulgarian herbs, Phytother Res. 20(11), 961-5.

Klimek, B., 1996. Hydroxycinnamoyl ester glycosides and saponins from flowers of Verbascum phlomoides, Phytochemistry 43(6),1281-1284.

Kostadinova, E., Alipieva, K., Stefova, M., Antonova, D., Evstatieva, Lj., Stefkov, G., Tsvetkova, I., Naydenski, H., Bankova, V., 2008. Influence of cultivation on the chemical composition and antimicrobial activity of Sideritis spp., Pharmacognosy Magazine 4 (14), 102-106.

Kostadinova, E., Nikolova, D., Alipieva, K., Stefova, M., Stefkov, G., Evstatieva, L., Matevski, V., Bankova, V., 2007. Chemical constituents of the essential oils of Sideritis scardica Griseb. and Sideritis raeseri Boiss and Heldr. from Bulgaria and Macedonia, Natural Product Research 21 (9), 819-823.

Kowalczyk, A., 1996. HPLC analysis of polyphenolic compounds in Knautia arvensis Coult, Beitrage zur Zuchtungsforschung Bundesanstalt fur Zuchtungsforschung an Kulturpflanzen 2(1), 389-392. Available at: http://eurekamag.com/ research/002/856/hplc-examination-polyphenoliccompounds-knautia-arvensis-coult.php

Kulevanova, S., Ristic, M., Stafilov, T., Dotrevski, K., Ristov, T., 1996. Essential oil analysis of some taxa of genera Thymus L. (environment influences), Bulletin of the Chemists and Technologists of Macedonia 15 (1), 33-38. Available at: http://www.mjcce.org.mk/PDF/15_1_218.pdf

Kulevanova, S., Ristic, M., Stafilov, T., Ristov, T., 1996. Composition of the essential oil from Thymus alsarensis Ronn. growing in Macedonia, Pharmazie 51 (4), 254-255.

Li, J.J., Tu, Y.Y., Tong, J.Z., Wang, P.T., 2000. Inhibitory activity of Dianthus superbus L. and 11 kinds of diuretic Traditional Chinese medicines for urogenital Chlamydia trachomatis in vitro, Zhongguo Zhong Yao Za Zhi 25(10), 628-30. http://pubget.com/paper/12516457/_Inhibitory_ activity_of_Dianthus_superbus_L__and_11_kinds_of_ diuretic_Traditional_Chinese_medicines_for_urogenital_ Chlamydia_trachomatis_in_vitro_

Lousewort (Pedicularis $-{ }^{-}$muscicola). http://www. martindalesnutrition.com/ns/DisplayMonograph.asp?StoreI $\mathrm{D}=$ le1jvdg81es92lh70g03n0et9d9x0r89\&DocID=bottomlin e-lousewort

Marais, J.P., Mueller-Harvey, I., Bandit, E.V., Ferreira, D. 2000 Polyphenols, condensed tannins, and other natural products in Onobrychis viciifolia (Sainfoin), J Agric Food Chem. 48(8):3440-7. Available at: http://www.ncbi.nlm.nih. gov/pubmed/10956131

Marino, M., Bersani, C., Comi, G., 1999. Antimicrobial activity of the essential oils of Thymus vulgaris L. measured using a bioimpedometric method, J Food Prot. 62(9), 1017-23.

Matevski, V., Micevski, K., Sekovski, Z., 1990. Thymus karadzicensis Matevski \& Micevski spec. nov. in der flora von Makedonien. Razprave IV razreda SAZU. 31(11),169178. Ljubljana
Matkowski, A., Woz'niak, D., Lamer-Zarawska, E., Oszmian'ski, J., Leszczyn'ska, A., 2003. Flavonoids and Phenol Carboxylic Acids in the Oriental Medicinal Plant Astragalus membranaceus Acclimated in Poland, Z. Naturforsch. 58c, 602Đ604. Available at: http://www.znaturforsch.com/ac/ v58c/s58c0602.pdf

Meister, A., Bernhardt, G., Christoffel, V., Buschauer, A., 1999. Antispasmodic activity of Thymus vulgaris extract on the isolated guinea-pig trachea: discrimination between drug and ethanol effects. Planta Med. 65(6), 512-6.

Меловски, Љ., Матевски, В., Костадиновски, М., Караделев, М., Ангелова, Н., Радфорд, Е., 2010. Значајни растителни подрачја во Република Македонија, Македонско еколошко друштво, Скопје.

Micevski K., Matevski, V., 1987. Teritorijalna podela endema u SR Makedoniji i problem njihove ugrozenosti, Akademija nauka i umetnostj Bosne i Hercegovine, Posebna izdanja Kniga LXXXIII, Odjeljenje prjrodnih I matematickih nauka Knjiga 14, 199-206.

Micevski, K., 1985. Flora in the Republic of Macedonia. MANU, 1(1):1-152

Micevski, K., 1993. Flora in the Republic of Macedonia. MANU, 1(2):153-391

Micevski, K., 1995. Flora in the Republic of Macedonia. MANU, 1(3):503-548

Micevski, K., 1998. Flora in the Republic of Macedonia. MANU, 1(4): 781-1113

Molnár, P., Szabolcs, J., 1980. Occurrence of 15-cis-violaxanthin in Violatricolor, Phytochemistry, 19 (4), 623-627.

Nature protection and biodiversity FYR Macedonia, European Environment Agency.

Novruzov, E.N., Ibadov, O.V., 1986. Anthocyanins of the flowers of plants of Tulipa genus, Chemistry of natural compounds 22 (2), 231-232. Available at: http://www.springerlink.com/ content/t044038832672060/

Pardo, F., Perich, F.,Torres, R., Delle Monache, F., 1998. Phytotoxic iridoid glucosides from the roots of Verbascum thapsus, Journal of chemical ecology 24(4), 645-653.

Piccaglia, R., Gaspari, F., Vecchiettini, M., 2003. Characterisation of an Italian wild sulla (Hedysarum coronarium L.), Proceedings of the $12^{\text {th }}$ Symposium of the European Grassland Federation, volume 8. Available at: www.cabdirect.org /abstracts/ 20053180468. html

Pizzale, L., Bortolomeazzi, R., Vichi, S., Uberegger, E., Conte L.S., 2002. Antioxidant activity of sage (Salvia officinalis and S fruticosa) and oregano (Origanum onites and $\mathrm{O}$ indercedens) extracts related to their phenolic compound content, Journal of the Science of Food and Agriculture 82 (14), 1645-1651.

Primorac, M., Sekulović, D., Antonić, S., 1985. In vitro determination of the spermicidal activity of plant saponins, Pharmazie 40(8), 585. Available at: http://linkedlifedata.com/ resource/pubmed/id/4080814

Rimkieni, S., Ragazinskieni, O., Savickieni, N., 2003. The cumulation of Wild pansy (Viola tricolor L.) accessions: the possibility of species preservation and usage in medicine, Medicina 39 (4), 411-416. Available at: http://medicina. kmu.lt/ 0304/0304-12e.pdf

Sarkar, M., Rashmi, R., Vikramaditya, Varma P.N., 1995. Pharmacognosy of Nepeta cataria, Anc Sci Life., 14(4), 225 234. Available at: www.ncbi.nlm.nih.gov/pmc/ articles/ PMC3331250/

Saxifraga granulata. Ayurvedic Herbs For UTI, Kidney 
Stone, Burning Sensation Of Urine. Available at: www.ayurveda-textbooks.com/ saxifraga-granulata.html

Šentjurc, M., Nemec, M., Connor, H.D., Abram, V., 2003. Antioxidant Activity of Sempervivum tectorum and its Components, J. Agric. Food Chem. 51 (9), 2766-2771. DOI: $10.1021 / \mathrm{jf0} 26029 \mathrm{z}$

Southon, S., Johnson, I.T., Gee, J.M., Price, K.R. ,1988. The effect of Gypsophila saponinsin the diet on mineral status and plasma cholesterol concentration in the rat, Br. J. Nutr. 59(1), 49-55.

Szarek-Łukaszewska, G., Słysz,A.,Wierzbicka,M.,2004. Response of Armeria maritima (Mill.) Willd. to $\mathrm{Cd}, \mathrm{Zn}$ and $\mathrm{Pb}$, Acta BiologicaCracoviensiaSeriesBotanica46,19-24.Availableat: www.ib.uj.edu.pl/abc/ pdf/46/02_szar.pdf

Takeda, K., Tominaga, S., 1983. The anthocyanin in blue fowers of Centaurea cyanus, Journal of plant research, J.Plant Res. 96 (4), 359-363. Available at: www.springerlink.com/ content/8v1381205u7h7657/

Tatli, I.I., Akdemir, Z.S., 2006, Traditional Uses and Biological Activities of Verbascum Species, FABAD J. Pharm. Sci. 31, 85-96. Available at: http://fabad.org/fabad.org/pdf/volum31/issue2/85-96.pdf

Toiu, A., Muntean, E., Oniga, I., Voştinaru, O., Tămaş, M., 2009, Pharmacognostic research on Viola tricolor L. (Violaceae), Rev Med Chir Soc Med Nat Iasi 113(1), 264-7.

Toiu, A., Pârvu, A.E., Oniga, I., Tămaş, M., 2007. Evaluation of anti-inflammatory activity of alcoholic extract from Viola tricolor, Rev Med Chir Soc Med Nat Iasi 111(2), 525-9.

Vukics, V., Kery, A., Bonn, G.K., Guttman, A., 2008a. Major flavonoid components of heartsease (Viola tricolor L.) and their antioxidant activities, Anal Bioanal Chem. 390(7), 1917-25.

Vukics, V., Kery, A., Guttman, A. 2008b Analysis of polar antioxidants in Heartsease (Viola tricolor L.) and Garden pansy (Viola $x$ wittrockiana Gams.), J Chromatogr Sci. 46(9), 823-7.

Втор национален извештај кон конвенцијата за климатски промени, Сектор биодиверзитет. Available at: http:// www.makmontana.org/Documents/Biodiversity_Status_in Macedonia_Report.pdf

Warashina, T., Miyase, T., Ueno, A., 1992. Phenylethanoid and lignan glycosides from Verbascum thapsus, Phytochemistry 31(3), 961-5.

Witkowska-Banaszczak, E., Bylka, W., Matławska, I., Goślińska, O., Muszyński, Z., 2005. Antimicrobial activity of Viola tricolor herb, Fitoterapia 76(5), 458-61.

Yilmaz, G., Demirci, B., Koyuncu, M., Baser, K.H.C., 2009. Composition of the fruit essential oils of four Heptaptera species growing in Turkey, Chemistry of natural compounds 4 (3), 431-433. DOI: 10.1007/s10600-009-9324-Z.

Zheng, Z., Liu, D., Song, C., Cheng, C., Hu, Z., 1998. Studies on chemical constituents and immunological function activity of hairy root of Astragalus membranaceus, Chin J Biotechnol. 14(2), 93-7. Available at: www.ncbi.nlm.nih.gov/pubmed/10196633

\title{
Pharmacognosticaly interesting endemic plant species in the flora of Republic of Macedonia
}

\author{
Jana Jovanovska, Gjoshe Stefkov, Marija Karapandzova
}

\author{
Institute of Pharmacognosy, Faculty of Pharmacy, University Ss Cyril and Methodius, Skopje, 1000 Skopje, Republic of \\ Macedonia
}

Key words: endemic plant species, Republic of Macedonia, pharmacognosy

Flora in the Republic of Macedonia comprises about 3200 species in 147 families. According to some sources there are 115 endemic higher plants, of which, 114 belong to gymnosperm. According to other sources, there are 135 species of endemic plants and about 111 of which are local endemic species and 24 are stretched in the border mountains. The exact number has not been determined yet. Eastern part of Macedonia, east of the river Vardar almost poses no endemics, while the rest of the territory, west of the Vardar is very rich in such species. The richest areas with endemic plants are Galicica Mountain, Treska River Gorge and the lowlands surrounding the city of Prilep.

Despite the wealth of endemic and relict species, any pharmacognostical data for these plants have not been published yet. Of all these endemic species, 30 could be pharmaconosticly interesting for future investigation of the chemical composition, isolation of potentially active substances and testing biological-pharmacological activity. Modern analytical techniques utilized in the examination of the chemistry of medicinal plants and natural products require a very small amount of material does not pose a risk of endangering endemic species. An additional challenge is the development of an appropriate program for the protection of all endemic, pharmaconosticly interesting species. 



\title{
Professional competences, credentialing and continuing professional development in the pharmacy profession
} - Model Framework for Patient Centered Pharmaceutical Care -

\author{
Renata Slaveska Raichki ${ }^{1}$, Vasilka Nicha ${ }^{2}$ and Tatjana Kadifkova Panovska ${ }^{1}$ \\ ${ }^{1}$ Faculty of Pharmacy, University "Ss Cyril and Methodius", Skopje \\ ${ }^{2}$ Public Institution in the Health Sector, for the needs of PHI University Clinics, Institute and Urgent Centre, Skopje
}

Received: June 2009; Accepted: July 2009

\begin{abstract}
The crucial changes have taken place in the role of pharmacy profession in the past decade. All these changes have been systematically evolved and adopted to support professional quality improvement aspect. In general, the worldwide professional and national authorities have been committed to develop the professional competencies, credentialing and continuing professional development; to emphasis the maintenance of high standards of professional development and in response to changes which occurred to pharmacy education and national health regulation policy. The constantly evolving health regulatory environment in each country will shape the progress of this process in the future.

This article provides a review of existing concepts for professional competences, credentialing and continuing professional development in pharmacy profession in an attempt to understand and clarify the complexity encountered in this comprehensive domain. It can also serve as a platform for the local interaction of a broad range of authorities in the health field.
\end{abstract}

Key words: pharmacy, competences, credentialing, continuing professional development, patient centered pharmaceutical care

\section{Introduction}

Drug therapy is the most frequently used form of treatment in any health practice setting. Namely, evidencebased practices confirm that drug therapy treatment has significantly increased due to the aging of world population, emerging of new infectious diseases, the prevalence of chronic diseases and increased number of patients who suffer from co-morbidities and require implementation of advanced multidrug therapy approach of complex nature (Kaplan and Laing, 2004). It must also be taken into account that community-based treatments for both acute and chronic illnesses that include newly developed therapies and act as the driving force towards outpatient surgeries have been related with the increased need of use of drugs. Moreover, with the development of the drug science and state-of-the art industrial technologies, the range of new efficient drugs has dramatically expanded. It is also worth to mention that the adoption and implementation of new health technologies created real opportunities for increased access to drugs. On the other hand, health technologies also alter the way of receiving health services and ultimately revolutionize healthcare operations. Nowadays, modern health facilities apply computerized dispensing techniques and devices. Since recently, drugs can also be obtained by mail order and via Internet. As far as the drugs are concerned, the increased number of prescriptions, and the increased number of available over-the-counter drugs (Fenichel, 2004), as a consequence focused the patient interest on self-directed care. The complexity of these features, as noted above, combined with these new circumstances have placed the pharmacist in a more prominent position in terms of providing more information and sophisticated services to patients. The new role of pharmacists requires improved platform of knowledge, skills, eth- 
ical attitude, and behavior that would contribute to the development of competently trained and adequately credentialed professionals.

The objective of this general overview is to present the first initiative of competency and categories of credentialing of pharmacy professionals, continual education of pharmacists and the best practices, with special focus on patient centered pharmaceutical care framework. This concept, developed and established in USA, due to its sophisticated characteristics has served as the model for Europe and other regions. The parallel concepts have also been developed for pharmacy technicians. However, they are not the subject of this overview. This overview, also presents the different aspects of the professional development and pharmacist's competencies that should be considered in our country, in the near future.

The process of achieving and maintaining the competency in the pharmacy profession and in the entire health care profession indeed, has been the subject of many support programs and initiatives which are to serve the public interest, healthcare professional oversight boards, pharmacy organizations, regulatory agencies, credentialing and governing boards (appendix A).

The basic principles underlying the roles and responsibilities of pharmacists are stated in the Code of Ethics for Pharmacists edited by American Pharmacists Association-APhA. (APhA, 2007). These principles, based on the moral obligations and qualities, are established in order to serve as a guidance for pharmacists in their relations with patients, health professionals, and society. Hence, defined basic principles include:

1. A pharmacist respects the covenantal relationship between the patient and pharmacist.

2. A pharmacist promotes the good of every patient in a caring, compassionate, and confidential manner.

3. A pharmacist respects the autonomy and dignity of each patient.

4. A pharmacist acts with honesty and integrity in professional relationships.

5. A pharmacist maintains professional competence.

6. A pharmacist respects the values and abilities of colleagues and other health professionals.

7. A pharmacist serves individual, community and societal needs.

8. A pharmacist seeks justice in the distribution of health resources

According to the fifth principle, it is obvious that professional competence is one of the key points in the pharmacy career.

The Institute of Medicine (IOM) identified five core competencies required for all health professionals (including pharmacists) aimed at optimizing patients' outcomes. They are the following: (I) deliver patient-centered care; (II) work as part of an interdisciplinary team; (III) practice evidence-based medicine; (IV) apply quality improvement approaches; and (V) use information technology. These competencies are the base for developing relevant standards and competence statements concerning healthcare professionals. The recommendations targeting oversight organizations include integrating these core competencies into accreditation, and certification processes across the professions. IOM challenges health care oversight agencies (licensing boards and certifying agencies) to abandon reliance on continuing education in favor of a more systematic approach that require each practitioner's competence be assessed, that interventions be targeted to specific deficiencies, and that each care-giver be tested to ensure that the desired competencies have been acquired and incorporated into practice. The employees must demonstrate professional judgment, ethics, attitudes, and values (Greiner and Knebel, 2003).

Citizen Advocacy Center (CAC) urges to put the subject of continual competence on the agendas of theirs and related organizations' meetings and conferences to generate considerable interest and support. Thus, at CAC Conference held in June, 2000, the National Association of Boards of Pharmacy (NABP) representative stated that:"there has been a philosophical change in the way consumers approach health care practitioners". It appeared that in the past, professionals used to say: "Trust me to be competent because I practice every day". But, at present, patients are saying: "Demonstrate to me that you are competent because my life and well being are in your hands" (CAC, 2001). Moreover, CAC recommended a five-step framework for assessing and demonstrating continual professional competence: (i) routine periodic assessment, (ii) development of a personal improvement plan, (iii) implementation of the improvement plan documentation (steps for quality improvement) and (iv) demonstration of competence (quality assurance step). The critical first step is routine periodic assessment. It serves as the key to identify knowledge deficiencies requiring correction and to tailor lifelong learning ${ }^{1}$ choices according to the needs of individual health care professionals. Assessment also reveals whether a practitioner applies his or her knowledge and skills competently in clinical situations.

In addition, Council on Credentialing in Pharmacy (CCP) adopted the following definition about competence in 2000, as follow: "The ability to perform one's duties accurately, make correct judgments, and interact appropriately with patients and with colleagues. Professional competence is characterized by good problem-solving and decision-making abilities, a strong knowledge base, and the ability to apply knowledge and experience to diverse patient-care situations" (CCP, 2006).

\footnotetext{
${ }^{1}$ Lifelong learning includes all learning activities undertaken throughout life, with the aim of improving knowledge, skills and competences within a personal, civic, social and/or employment-related perspective (ECD,2003).
} 
It is more than clear that the pharmacists intend to take leadership roles in improving the use of medicines, which they cannot accomplish if working do in isolation from the many others professionals involved in the medicines use process (WHO, 2006).

\section{Tasks and Functions of Pharmacists and Future Vision of Pharmacy Practice}

Contemporary pharmacy practice reflects an evolving pattern: from having a primary role in medicine distribution and advising patients to a much broader and teambased clinical role which includes provision of patient centered medicine therapy management, health improvement, and disease prevention services. Thus, the pharmacy practice integrates fields that are directly related to the patient and performed in community pharmacy, ambulatory care clinics, hospitals, long-term care facilities, home-care institutions, and managed-care organizations.

However, other roles of pharmacists are practiced in the pharmaceutical industry, research and development, national agencies, academia, associations, and a number of unique healthcare practices such as drug and poison information centers that are not directly related to patient care.

The Model State Pharmacy Act and Model Rules of the NABP define the practice of pharmacy as follows: The "Practice of Pharmacy" means the interpretation, evaluation, and implementation of Medical Orders; the Dispensing of Prescription Drug Orders; participation in Drug and Device selection; Drug Administration; Drug Regimen Review; the Practice of Telepharmacy within and across state lines; Drug or Drug-related research; the provision of Patient Counseling; the provision of those acts or services necessary to provide Pharmacist Care in all areas of patient care, including Primary Care and Collaborative Pharmacy Practice; and the responsibility for Compounding and Labeling of Drugs and Devices (except Labeling by a Manufacturer, Re-packager, or Distributor of Non-Prescription Drugs and commercially packaged Legend Drugs and Devices), proper and safe storage of Drugs and Devices, and maintenance of required records.

The practice of pharmacy also includes continually optimizing patient safety and quality of services through effective use of emerging technologies and competencybased training (NABP, 2006).

Following the third Joint Commission of Pharmacy Practitioners (JCPP) - "Pharmacy in the $21^{\text {st }}$ Century", at the Conference in 1994, a collaborative effort of ten national pharmacy organizations led to the development of the Pharmacist Practice Activity Classification (PPAC), a hierarchical categorization of pharmacist activities (Table 1). The PPAC is focused primarily on activities of licensed, practicing pharmacists across the continuum of health care settings. The PPAC also includes activities that are either delegated by pharmacists to technicians or are carried out by automated systems. The PPAC facilitates the compara- ble data among studies, such as: building databases for statistical purposes about pharmacists'; patient-centered activities (to improve patient outcomes); the use of resources and provides a solid foundation to support systems for payment model that can be used for billing. The classification captures a range of activities from a traditional dispensingbased practice towards a higher level of patient care and direct patient care services.

This document classify pharmacy practice activities as follows: the highest level is the Domain or field of activity where four major domains of pharmacist activities have been identified. Within each domain there are more specific Classes of Activities. Within each Class there are Activities or Interventions - labels for sets of specific behaviors that, based on their professional knowledge and clinical judgment, pharmacists engage in as a part of their professional practice to enhance patient care and outcomes. Under many of the activities, one or more Tasks are specified. Some tasks are further divided into distinct Steps. Each entry has a unique alphanumeric identity. It is expected that this design will allow for easy and timely modification of the system (Maine,1998)-Table 1.

Table 1. Pharmacist Practice Activity Classification (PPAC); Domain and Classes related to practice activity

\begin{tabular}{|c|c|}
\hline Domain & Class \\
\hline $\begin{array}{l}\text { A. Ensuring } \\
\text { Appropri- } \\
\text { ate Thera- } \\
\text { py and Out- } \\
\text { comes }\end{array}$ & $\begin{array}{l}\text { A.1. Ensuring appropriate pharmacothera- } \\
\text { py } \\
\text { A.2. Ensuring patient's understanding/ad- } \\
\text { herence to his or her treatment plan } \\
\text { A.3. Monitoring and reporting outcomes }\end{array}$ \\
\hline $\begin{array}{l}\text { B. Dispensing } \\
\text { Medications } \\
\text { and De- } \\
\text { vices }\end{array}$ & $\begin{array}{l}\text { B.1. Processing the prescription or drug or- } \\
\text { der } \\
\text { B.2. Preparing the pharmaceutical product } \\
\text { B.3. Delivering the medication or device }\end{array}$ \\
\hline $\begin{array}{l}\text { C. Health Pro- } \\
\text { motion and } \\
\text { Disease } \\
\text { Prevention }\end{array}$ & $\begin{array}{l}\text { C.1. Delivering clinical preventive servic- } \\
\text { es } \\
\text { C.2. Surveillance and reporting of public } \\
\text { health issues } \\
\text { C.3. Promoting safe medication use in so- } \\
\text { ciety }\end{array}$ \\
\hline $\begin{array}{l}\text { D. Health Sys- } \\
\text { tems Man- } \\
\text { agement }\end{array}$ & $\begin{array}{l}\text { D.1. Managing the practice } \\
\text { D.2. Managing medications throughout the } \\
\text { health system } \\
\text { D.3. Managing the use of medications with- } \\
\text { in the health system } \\
\text { D.4. Participating in research activities } \\
\text { D.5. Engaging in interdisciplinary collab- } \\
\text { oration }\end{array}$ \\
\hline
\end{tabular}

According to the well known consensus document: "The Future Vision for Pharmacy Practice 2015" that has 
been officially adopted by the JCPP: "Pharmacists will be the healthcare professionals responsible for providing patient care that ensures optimal medication therapy outcomes. "The concept of "optimal medication therapy" implies that the use of medicines occurs within a system that assures the highest possibility of achieving desired clinical, humanistic, and economic outcomes. The "JCPP Vision" further states that: "Pharmacists will benefit society and be essential to the provision of effective health care by ensuring that: (a) medication therapy management is readily available to all patients;(b) desired patient outcomes are more frequently achieved; (c) overuse, underuse, and misuse of medications are minimized; (d) medication-related public health goals are more effectively achieved; and (e) cost effectiveness of medication therapy is optimized" (JCPP, 2004)

With the aim of achieving the mission of pharmacy profession and fulfilling these professional activities, a sound pharmacists' education and numerous post-graduate studies and training opportunities have been introduced and made available to pharmacists.

\section{Professional competencies addressing pharmacy practice}

\section{Competency based education - credential needed to prepare for pharmacy practice}

Miller, graded the competency-based education on four levels: the learner knows the facts (cognition), knows how to apply the facts, shows how (in a controlled environment) and does (behavior, in real situations) (Miller,
1990). At the beginning, the curricula lead the learner from dependent and directed towards independent, self-directed and lifelong learner. Pharmaceutical education needs to develop content and process of the educational curriculum that is required to prepare students to render pharmaceutical care at the entry points in the health care system.

As concerns the competency based education, accreditation standards and guidelines have been established for the Professional Program in Pharmacy leading to the Doctor of Pharmacy Degree by the Accreditation Council for Pharmacy Education-ACPE (ACPE, 2006). According to Standard No. 9, the Goal of the Curriculum is: "The college or school's professional degree curriculum must equip the graduates with professional competencies in order to enter the pharmacy practice in any setting and ensure optimal medication therapy outcomes and patient safety, satisfy the educational requirements for obtaining a license as a pharmacist, and meet the requirements for the university degree. The curriculum must provide the graduates with knowledge that meets the criteria of good science; professional skills, attitudes, and values; and the ability to integrate and apply learning to both the present practice of pharmacy and the advancement of the profession. Graduates must be able to identify and implement needed changes in pharmacy practice and health care delivery".

The AACP (American Association of Colleges of Pharmacy) proposed a series of initiatives under the Center for the Advancement of Pharmaceutical Education (CAPE) with the aim of supporting and facilitating the efforts of colleges and schools of pharmacy in the US for transforming their curricula and supporting the education of future practitioners to deliver pharmaceutical care. Important fea-

Table 2. Alignment of AACP CAPE educational outcomes and ACPE Standard No.12

\begin{tabular}{|c|c|c|c|}
\hline \multirow{2}{*}{$\begin{array}{l}\text { AACP CAPE Edu- } \\
\text { cational outcomes } \\
2004\end{array}$} & $\begin{array}{l}\text { Outcome 1: } \\
\text { Pharmaceutical care }\end{array}$ & $\begin{array}{l}\text { Outcome 2: } \\
\text { System managements }\end{array}$ & $\begin{array}{l}\text { Outcome 3: } \\
\text { Public health }\end{array}$ \\
\hline & $\begin{array}{l}\text { *Provide patient-centered care } \\
\text { *Provide population-based care }\end{array}$ & $\begin{array}{l}\text { *Manage human, physical, medi- } \\
\text { cal, informational and technolog- } \\
\text { ical resources } \\
\text { *Manage medication use systems }\end{array}$ & $\begin{array}{l}\text { *Assure the availability of ef- } \\
\text { fective, quality health and dis- } \\
\text { ease prevention services } \\
\text { *Develop public health policy }\end{array}$ \\
\hline $\begin{array}{l}\text { Standard No.12 } \\
\text { Professional Com- } \\
\text { petencies and Out- } \\
\text { come Expectations }\end{array}$ & $\begin{array}{l}\text { Provide patient care in cooperation with: } \\
\text { - patients, } \\
\text { - prescribers, and } \\
\text { of an interprofessional health care team } \\
\text { based upon sound therapeutic principles } \\
\text { and evidence-based data, taking into ac- } \\
\text { count relevant legal, ethical, social, cul- } \\
\text { tural, economic, and professional issues, } \\
\text { emerging technologies, and evolving bio- } \\
\text { medical, pharmaceutical, social/behav- } \\
\text { ioral/administrative, and clinical sciences } \\
\text { that may impact therapeutic outcomes. }\end{array}$ & $\begin{array}{l}\text { Manage and use resources of the } \\
\text { health care system, in cooperation } \\
\text { with: } \\
\text { - patients, } \\
\text { - prescribers, } \\
\text { other health care providers, } \\
\text { administrative and } \\
\text { supportive personnel, } \\
>\text { to promote health; } \\
>\text { to provide, assess, and co- } \\
\text { ordinate safe, accurate, and } \\
\text { time-sensitive medication } \\
\text { distribution; and } \\
>\text { to improve therapeutic out- } \\
\text { comes of medication use. }\end{array}$ & $\begin{array}{l}\text { Promote health improvement, } \\
\text { wellness, and disease preven- } \\
\text { tion in cooperation with: } \\
\text { - patients, } \\
\text { - communities, } \\
\text { - at-risk populations, and } \\
\text { of an interprofessional team of } \\
\text { health care providers. }\end{array}$ \\
\hline
\end{tabular}


tures of the design of the new curricula were the CAPE Educational Outcomes, which the evolving pharmacy curriculum should pursue. Upon request by 2001-02 AACP Academic Affairs and Professional Affairs Committees, the AACP Board of Directors committed to review and revise the CAPE Educational Outcomes during 2003-04. The result of this revision, CAPE Educational Outcomes 2004 provided a framework that integrated the professionalism, inter-professional practice, ethical attitudes and behaviors, and basic science across three expected educational outcomes: (i) Pharmaceutical Care, (ii) Systems Management, and (iii) Public Health in order to meet the mandate of this mission (AACP, 2004). Pursuant to this framework, ACPE adopted the CAPE Educational Outcomes with minor modifications. AACP CAPE educational outcomes and Standard No.12 are summarized in Table 2. It was noted that a periodic review and revision should be conducted in order to ensure the contemporary validity of the educational content and outcomes with emerging sciences and scientific developments and evolving roles of the pharmacists in serving patient and public health needs.

Problem-based curricula have been introduced at universities in a number of countries (Savery, 2006). These standards are used to assess health professionals' knowledge and skills during in reregistration examinations or during the continual professional development (CPD). In fact, CPD including research and reflecting the outcomes of actions contributes to maintaining the life-long competency to practice. CPD framework will be elaborated in the text below.

\section{Credentials that needs to enter into practice and renew professional knowledge and skills.}

NAPB, as an association of state boards of pharmacists, assists its member boards and jurisdictions in developing, implementing, and enforcing uniform standards for the purpose of protecting the public health. NAPB develops diversity of programs such as: examination, licensure, assessment, consumer protection, accreditation and $\mathrm{CPE}$ monitor.

One of the NABP examination programs is the North American Pharmacist Licensure Examination $\left(\right.$ NAPLEX $\left.^{\circledR}\right)$ (Newton, Boyle and Catizone, 2008). NAPLEX is the principal licensure examination that must be passed by all graduates from an accredited professional degree program in pharmacy in order to obtain licensure and practice as a pharmacist. In this instance, candidates are licensed to practice after having: (I) a degree in pharmacy ap- proved by the board, (II) have completed the minimum number of hours in practice; and (III) have passed the licensing examination.

The NAPLEX assesses the ability of a prospective pharmacist to identify the practice standards for safe and effective pharmacotherapy; optimize therapeutic outcomes in patients; determine safe and accurate methods to prepare and dispense medications; and provide and apply health care information to promote optimal health care. In 1996, the NAPLEX introduced the computer adaptive testing (CAT) model to the professional pharmacy. The CAT NAPLEX is designed according to a set of specific knowledge areas and practice functions and skills, i.e. the Competency Statements or Competencies published in the Blueprint (NABP, 2006), Table 3. The ACPE Standards are some of the reference sources for determining the NAPLEX Blueprint. The Blueprint reflects the knowledge, judgment, and skills to be demonstrated by an entry-level pharmacist to protect the health and welfare of his or her patients.

There is no doubt that AACP CAPE Educational Outcomes 2004, ACPE Standard No.12 Professional Competencies and Outcome Expectations, NAPLEX ${ }^{\circledR}$ Blueprint and the PPAC are closely related to the five core competencies applicable to all healthcare professionals and recently identified by the IOM.

However, NAPLEX should not be considered as the final examination of the college's or school's curricula. Therefore, in 2005, NABP introduced the Pharmacists Self-Assessment Mechanism (PSAM) (NAPB, 2005). The PSAM is 100 questions assessment for pharmacists to evaluate their professional practice skills and knowledge. The PSAM Blueprint Competencies are similar to those of NAPLEX. Moreover, the MPJE (Multistate Pharmacy Jurisprudence Examination), combines federal and state-specific questions to test the pharmacy jurisprudence knowledge of prospective pharmacist. It serves as the pharmacy law examination in participating jurisdictions. Graduates from foreign colleges of pharmacy must document that they have education and experience equivalent to their UStrained colleagues. They must also pass the Foreign Pharmacy Graduate Equivalency Examination (FPGEE), the Test of English as a Foreign Language (TOEFL), and the Test of Spoken English (TSE). Once these requirements are met, they receive the Foreign Pharmacy Graduate Examination Committee's (FPGEC) certificate. In addition to the NAPLEX ${ }^{\circledR}$ and MPJE $^{\circledR}$, some US states require a laboratory examination or an oral examination before licensure is conferred.

Table 3. NABP NAPLEX® Blueprint-competency statements

\begin{tabular}{ll}
\hline Area 1 & Assure Safe and Effective Pharmacotherapy and Optimize Therapeutic Outcomes \\
Area 2 & Assure safe and Accurate Preparation and Dispensing of Medications \\
Area 3 & Provide Health Care Information and Promote Public Health \\
\hline
\end{tabular}


All state boards also require that candidates complete an internship before being licensed. The internship may be completed during the candidate's academic training or after graduation, depending on the state requirements. An internship requirement traditionally requires a pharmacy student to work in a licensed pharmacy under the supervision of a board-registered pharmacist or to complete-collegecoordinated clerkships as equivalent to (or as a significant portion of) state-mandated internships- A license to practice Pharmacy as a Pharmacy Intern shall be granted only to those individuals who:(1) are enrolled in a professional degree program of a school or college of pharmacy that has been approved by the Board and satisfactorily progressing toward meeting the requirements for licensure as a Pharmacist; or (2) are graduates of an approved professional degree program of a school or college of Pharmacy or are graduates who have established educational equivalency by obtaining a Foreign Pharmacy Graduate Examination Committee $^{\mathrm{TM}}\left(\right.$ FPGEC $\left.^{\circledR}\right)$ Certificate, who are currently licensed by the Board of Pharmacy for the purpose of obtaining practical experience as a requirement for licensure as a Pharmacist; or (3) are qualified applicants awaiting examination for licensure or meeting Board requirements for re-licensure; or (4) are participating in a residency or fellowship program.

Licensure renewal: licensure renewal is mandatory for pharmacists who wish to continue to practice their profession. All member state boards of pharmacy require that registered pharmacists complete a minimum number of hours or continual education units (CEUs) before they can renew their licenses. Continual education is defined by CCP as: Organized learning experiences and activities in which pharmacists engage after they have completed their entry-level academic education and training. These experiences are designed to promote the continuous development of the skills, attitudes, and knowledge needed to maintain proficiency, provide quality servicer products, respond to patient needs, and keep abreast of change (CCP, 2001).

More recently (June 2003), ACPE adopted the following definition: Continuing education for the profession of pharmacy is a structured process of education designed or intended to support the continuous development of pharmacists to maintain and enhance their professional competence. Continuing education should promote problemsolving and critical thinking and be applicable to the practice of pharmacy (ACPE, 2003).

The candidate for licensure renewal may acquire a number of CEUs by attending educational seminars, teleconferences, meetings reading journal articles, completing home study courses or computer-based educational programs (CCP, 2006).

The hours or CEUs must be earned either through participation in a continuing education (CE) program whose provider has been accredited by the ACPE, or through a program or activity, which has been otherwise approved by the state board. Achievement of a satisfactory score on an assessment that is created by and submitted to the CE provider is generally required as a documentation of completion of a CE program.

The ACPE has established accreditation standards for providers of continuing pharmacy education. The majority of ACPE-approved providers are professional pharmacy organizations, colleges of pharmacy, and pharmaceutical companies. Each program is reviewed every 6 years by the ACPE. ACPE re-evaluates the CE model in pharmacy through a process of identification of the $\mathrm{CE}$ requirements of other organizations, exploration of the CE processes and activities of other health professions, domestic and international, including the use of new models, such as CPD. Also, ACPE is exploring the re-engineering of the CE provider accreditation process to make it more efficient and effective, while fostering continuous quality improvement and encouraging innovation (ACPE, 2001).

\section{Professional development and enhanced competency of pharmacist}

While, academic degrees in the field of pharmacy, state licensure and re-licensure are obligated, mandatory, other credentials (postgraduate degrees, certificates and certification), pharmacists earn to document their specialized or advanced knowledge and skills on voluntary bases. Pharmacy practitioners who have completed programs of various types that are intended to develop and enhance their knowledge and skills or those who have successfully documented a specialized level of knowledge and skills through an assessment process are awarded appropriate qualification-Many different organizations (public and private) are directly involved in assessing pharmacists' knowledge and skills, granting credentials and certificates, and accrediting educational programs and institutions. Post-licensure training programs and credentials are competency-based, developed on the basis of a comprehensive practice analysis in the relevant areas, and offered or accredited by an organization that adhere to the accepted principles and practices to assure quality, integrity, and validity. A pharmacist's credentials are indicators that he or she holds the qualifications needed to practice the profession of pharmacy and is therefore worthy of the trust of patients, of other health care professionals and of the society as a whole (CCP, 2006; Scope of Contep. PP, 2009).

The three categories of pharmacist credentials and oversight bodies are illustrated in Figure 1.

\section{Academic Postgraduate Education and Training}

Postgraduate master's (M.S.) programs cover common fields of studies: business administration, clinical pharmacy and public health.

Postgraduate doctor of philosophy (Ph.D.) programs cover common fields of studies: pharmacology, pharmaceutics, pharmaceutical and medicinal chemistry, pharma- 


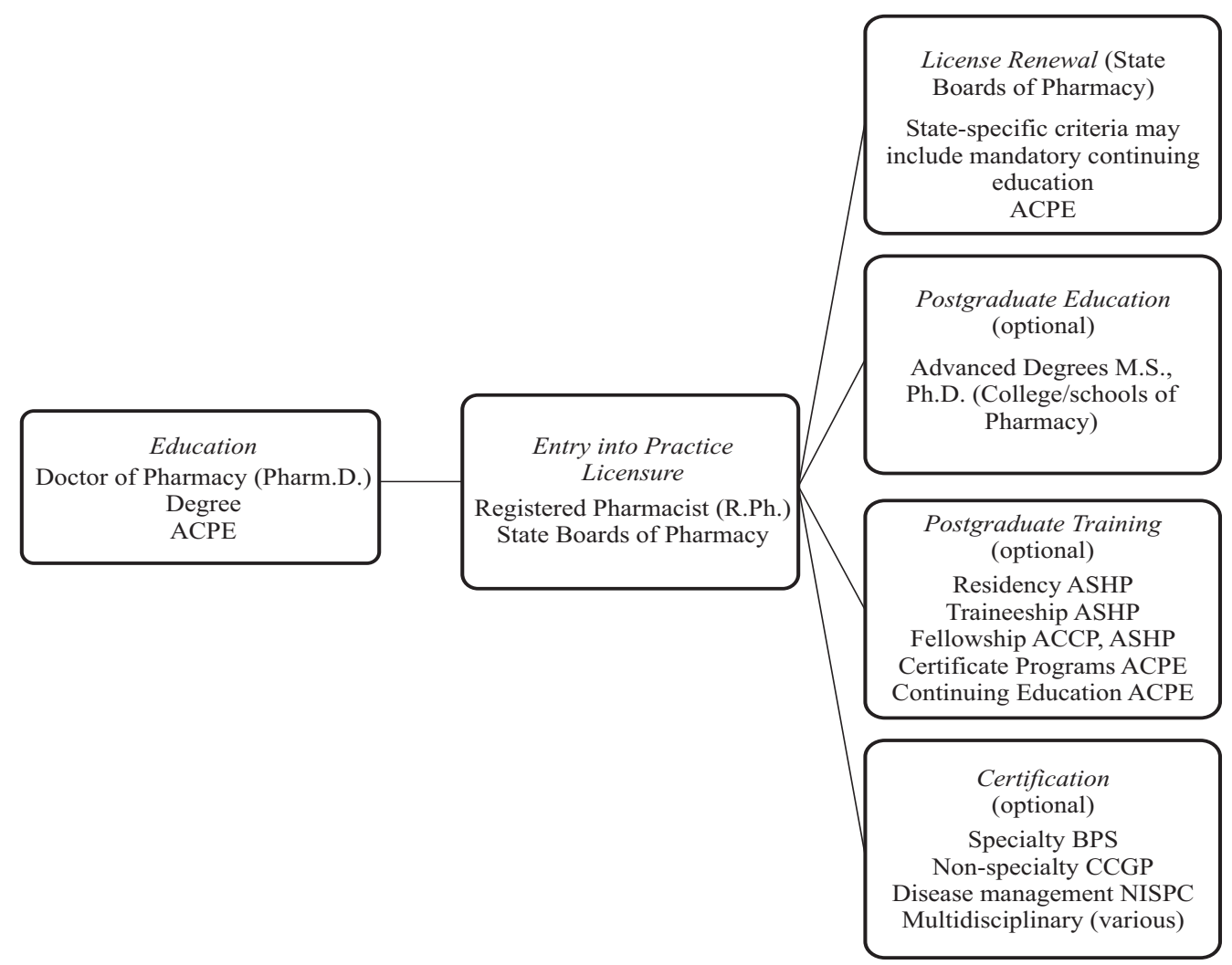

Figure 1. Pharmacy Credentials and Oversight Bodies for Pharmacists in U.S.

cotherapeutics, pharmacy practice and social and administrative scie nces.

\section{Residency Training program (Credential acquired: Res- idency Certificate)}

A residency is an organized, directed postgraduate program, accredited by American Society of Health-System Pharmacists (ASHP) independently or in collaboration with other pharmacy organizations in a defined area of pharmacy practice. Residencies usually last 12 months, although certain specialized residencies require additional 12 (or continuous 24) months for completion - Table 4.

\section{Pharmacy practice residencies - PGY1 (Post Graduate Year one)}

Pharmacy practice residencies focus on the development of the resident of professional competence in the delivery of patient care (providing optimum medication therapy outcomes) and practice management activities (managing medication use process). This program provides an environment and structure for accelerating the growth and experience beyond entry-level professional competence through supervised practice under the guidance of model practitioners in "real-world" settings (hospital, community pharmacy, managed care organization, home or long term care practice). Residents are exposed to a wide range of patients with multiple diseases, chronic or acute, and work with a variety of health professionals, thereby advancing their clinical, interpersonal, and leadership skills.

\section{Specialized pharmacy practice residencies PGY2 (Post Graduate Year two)}

Specialized pharmacy practice residencies focus on the knowledge, skills, attitudes and abilities to raise the resident's level of expertise needed to provide care in a specialized area of pharmacy practice (e.g., critical care, drug information, pharmacotherapy, or oncology). This specialized residency training is an organized, directed, accredited program that builds upon the competencies established in pharmacy practice residencies, after the first year of residency training. The second year of postgraduate residency training involves additional education and pharmacists obtain more in-depth training and experience. In partnership with the APhA for Community Pharmacy, and the Academy of Managed Care Pharmacy (AMCP) for Managed Care, the American Society of Health-System Pharmacists' Research and Foundation has established residency standards and reviews for programs that include community and managed care pharmacy residencies. The National Association of Chain Drug Stores (NACDS) and National Community Pharmacists Association (NCPA) sup- 
Table 4. Residency Programs

\section{Residency Programs Accredited by ASHP Commission on Credentialing}

Pharmacy practice

Pharmacy practice residency (traditionally conducted in health systems)

$>\quad$ Pharmacy practice with emphasis on community pharmacy

$>$ Pharmacy practice with an emphasis on managed care

$>$ Pharmacy practice with an emphasis on home care

$>$ Pharmacy practice with an emphasis on long-term
Specialized Residencies

- Cardiology,

- Clinical pharmacokinetics,

- Critical care,

- Drug information,

- Emergency medicine,

- Geriatrics,

- Infectious diseases,

- Internal medicine,

- Managed care pharmacy systems,

- Nuclear pharmacy,

- Nutrition support,

- Oncology,

- Pediatrics,

- Pharmacotherapy,

- pharmacy practice management,

- Primary care,

- Psychiatric ported community pharmacy residency programs, including development of the NACDS/NCPA community pharmacy residency guidelines. The Institute for the Advancement of Community Pharmacy, (an organization founded by the NACDS and NCPA), has provided grants to encourage schools of pharmacy and community pharmacies to develop additional community pharmacy residency programs nationwide (Sheaffer, 2004).

\section{Fellowships (Credential acquired: Fellowship Certif- cate)}

Fellowship is direct, highly individualized postgraduate program that prepares the participant to become an independent researcher in an area of pharmacy practice. Fellowship programs are developed by faculties of pharmacy, academic health centers, universities, pharmaceutical manufacturers and usually last one to two years. ACCP (American College of Clinical Pharmacy) has developed guidelines for organization of clinical fellowships. To improve the consistency in the quantity and quality of the research experience, the ACCP has implemented a process for peer review of pharmacy fellowship training programs. If the specialist qualifications and the training program meet the guidelines based on a review by the ACCP Fellowship Review Committee, they are recognized and the program and specialist are listed on the ACCP Web site (CCP, 2006). Otherwise, there is no formal accreditation process.

\section{Certificate Programs (Credential earned: Certificate of Completion)}

A certificate program is a structured and systematic postgraduate continuing education experience for pharmacists that is smaller in magnitude and shorter in duration than degree programs. Certificate programs are offered by national and state pharmacy organizations and by schools and colleges of pharmacy and other educational groups (CCP, 2006). The design of certificate programs includes didactic instruction, practice experiences, simulations, and/ or other opportunities for the demonstration of desired professional competencies. Attributes that differentiate certificate program from CE programs are practice experiences, simulations and other activities for demonstration of stated competencies. The length of any particular certificate program is determined by its stated goals, desired professional competencies and outcome measures. This generally requires a minimum of 15 contact hours (1.5 CEUs). Certificate programs are designed to instill, expand, or enhance practice competencies through the systematic acquisition of specified knowledge, skills, attitudes, and behaviors. For example, the APhA offers programs in such areas as asthma, diabetes, immunization delivery, and management of dyslipidemias. The value of these programs depends on individuals' goals or in instances when an employer or regulatory body recognizes the importance of the certificate. Examples are state boards of pharmacy that allow pharmacists to administer vaccines, after they have completed a certificate program in vaccine administration.

\section{Traineeships}

In contrast to certificate programs, traineeships allow practicing pharmacists abbreviated clinical training experience through intensive, individualized, structured postgraduate programs (combination of self-study and didac- 
Table 5. Programs, Credentialing Agencies and credentials acquired

\begin{tabular}{|c|c|c|}
\hline Anticoagulation & $\begin{array}{l}\text { National Institute for Standards for Pharmacist Creden- } \\
\text { tialing (NISPC) } \\
\text { National Certification Board for Anticoagulation Pro- } \\
\text { viders (NCBAP) }\end{array}$ & $\begin{array}{l}\text { Certified Anticoagulation Care Provider } \\
(\mathrm{CACP})\end{array}$ \\
\hline Asthma & $\begin{array}{l}\text { National Institute for Standards for Pharmacist Creden- } \\
\text { tialing (NISPC) } \\
\text { National Asthma Educator Certification Board } \\
\text { (NAECB) }\end{array}$ & Certified Asthma Educator (AE-C) \\
\hline Diabetes & $\begin{array}{l}\text { National Institute for Standards for Pharmacist Creden- } \\
\text { tialing (NISPC) } \\
\text { National Certification Board for Diabetes Educators } \\
\text { (NCBDE) } \\
\text { American Nurses Credentialing Center (ANCC) }\end{array}$ & $\begin{array}{l}\text { Certified Disease Manager (CDM) } \\
\text { Certified Diabetes Educator (CDE) } \\
\text { Board Certified-Advanced Diabetes } \\
\text { Management (BC-ADM) }\end{array}$ \\
\hline Dyslipidemia & $\begin{array}{l}\text { National Institute for Standards for Pharmacists } \\
\text { (NISPC) }\end{array}$ & Certified Disease Manager (CDM) \\
\hline Geriatrics & $\begin{array}{l}\text { Commission on Certification in Geriatric } \\
\text { Pharmacy }(\text { CCGP })\end{array}$ & $\begin{array}{l}\text { Certified } \\
\text { Geriatric Pharmacist (CGP) }\end{array}$ \\
\hline Life Support & American Heart association & $\begin{array}{l}\text { Advanced Cardiovascular Life Support } \\
\text { Certification (ACLS) } \\
\text { Pediatric Cardiovascular Life Support } \\
\text { Certification (PALS) }\end{array}$ \\
\hline Lipids & $\begin{array}{l}\text { National Institute for Standards for Pharmacist Creden- } \\
\text { tialing (NISPC) } \\
\text { Accreditation Council for Clincal Lipidology }\end{array}$ & $\begin{array}{l}\text { Certified Disease Manager (CDM) } \\
\text { Clinical Lipid Specialist }\end{array}$ \\
\hline Nuclear & Board of Pharmaceutical Specialties (BPS) & $\begin{array}{l}\text { Board Certified Nuclear Pharmacist } \\
(\mathrm{BCNP})\end{array}$ \\
\hline Nutrition Support & Board of Pharmaceutical Specialties (BPS) & $\begin{array}{l}\text { Board Certified Nutrition Support Phar- } \\
\text { macist (BCNSP) }\end{array}$ \\
\hline Oncology & Board of Pharmaceutical Specialties (BPS) & $\begin{array}{l}\text { Board Certified Oncology Pharmacist } \\
\text { (BCOP) }\end{array}$ \\
\hline Pain Management & American Academy of Pain Management (AAPM) & Credentialed Pain Practitioner (CPP) \\
\hline Pharmacotherapy & Board of Pharmaceutical Specialties (BPS) & $\begin{array}{l}\text { Board Certified Pharmacotherapy Spe- } \\
\text { cialist (BCPS) }\end{array}$ \\
\hline $\begin{array}{l}\text { Pharmacothera- } \\
\text { py with Addition- } \\
\text { al Qualifications in } \\
\text { Cardiology }\end{array}$ & Board of Pharmaceutical Specialties (BPS) & $\begin{array}{l}\text { Board Certified Pharmacotherapy Spe- } \\
\text { cialist (BCPS) }\end{array}$ \\
\hline $\begin{array}{l}\text { Pharmacothera- } \\
\text { py with Addition- } \\
\text { al Qualifications in } \\
\text { Infectious Diseases }\end{array}$ & Board of Pharmaceutical Specialties (BPS) & $\begin{array}{l}\text { Board Certified Pharmacotherapy Spe- } \\
\text { cialist (BCPS) }\end{array}$ \\
\hline Poison Information & American Association of poison Control Centers & $\begin{array}{l}\text { Certified Specialist in Poison Informa- } \\
\text { tion (CSPI) }\end{array}$ \\
\hline Psychiatry & Board of Pharmaceutical Specialties (BPS) & $\begin{array}{l}\text { Board Certified Psychiatric Pharmacists } \\
\text { (BCPP) }\end{array}$ \\
\hline Toxicology & American Board of Applied Toxicology & $\begin{array}{l}\text { Diplomat of the American Board of Ap- } \\
\text { plied Toxicology (DABAT) }\end{array}$ \\
\hline
\end{tabular}


tic instruction) under supervision of a pharmacist practicing in a given specialty. These programs provide the participants with the knowledge and skills needed to give a high level of care to patients with various chronic diseases and conditions. Traineeships are generally of longer duration (about five days) and involve smaller groups of trainees than certificate programs. Examples of such programs are anticoagulation management, critical care pharmacy, and diabetes management. These programs are commonly offered through the foundations of professional organizations such as the American College of Apothecaries, (ACA), American Society of Consultant Pharmacists (ASCP), and ASHP and are often supported by grants from the pharmaceutical industry.

\section{Certification}

Certification is "voluntary process by which a nongovernmental agency or an association grants recognition to an individual who has met certain predetermined qualifications specified by that organization". The credentials are granted to pharmacists and other health professionals who have demonstrated a level of competence in a well-defined, specific and relatively narrow area of practice. Certification is granted on the basis of successful completion of rigorously developed eligibility criteria that include a written examination and, in some cases, an experiential component. Also, certification usually requires initial assessment and periodic reassessments of the individual's knowledge, skills and/or experience. The certification process is undertaken and overseen by the Board of Pharmaceutical Specialties (BPS), the Commission on Certification in Geriatric Pharmacy (CCGP), and the National Institute for Standards in Pharmacist Credentialing (NISPC).

\section{Specialty certification (Credential acquired: Certifica- tion in area of practice).}

Pharmacists are certificated in five specialties by the BPS: (1) nuclear pharmacy; (2) nutrition support pharmacy; (3) oncology pharmacy; (4) pharmacotherapy and (5) psychiatric pharmacy. Later on, in 1997, BPS introduced the designation of "Added Qualifications" to denote that an individual has demonstrated an enhanced level of training and experience in one segment of a BPS-recognized

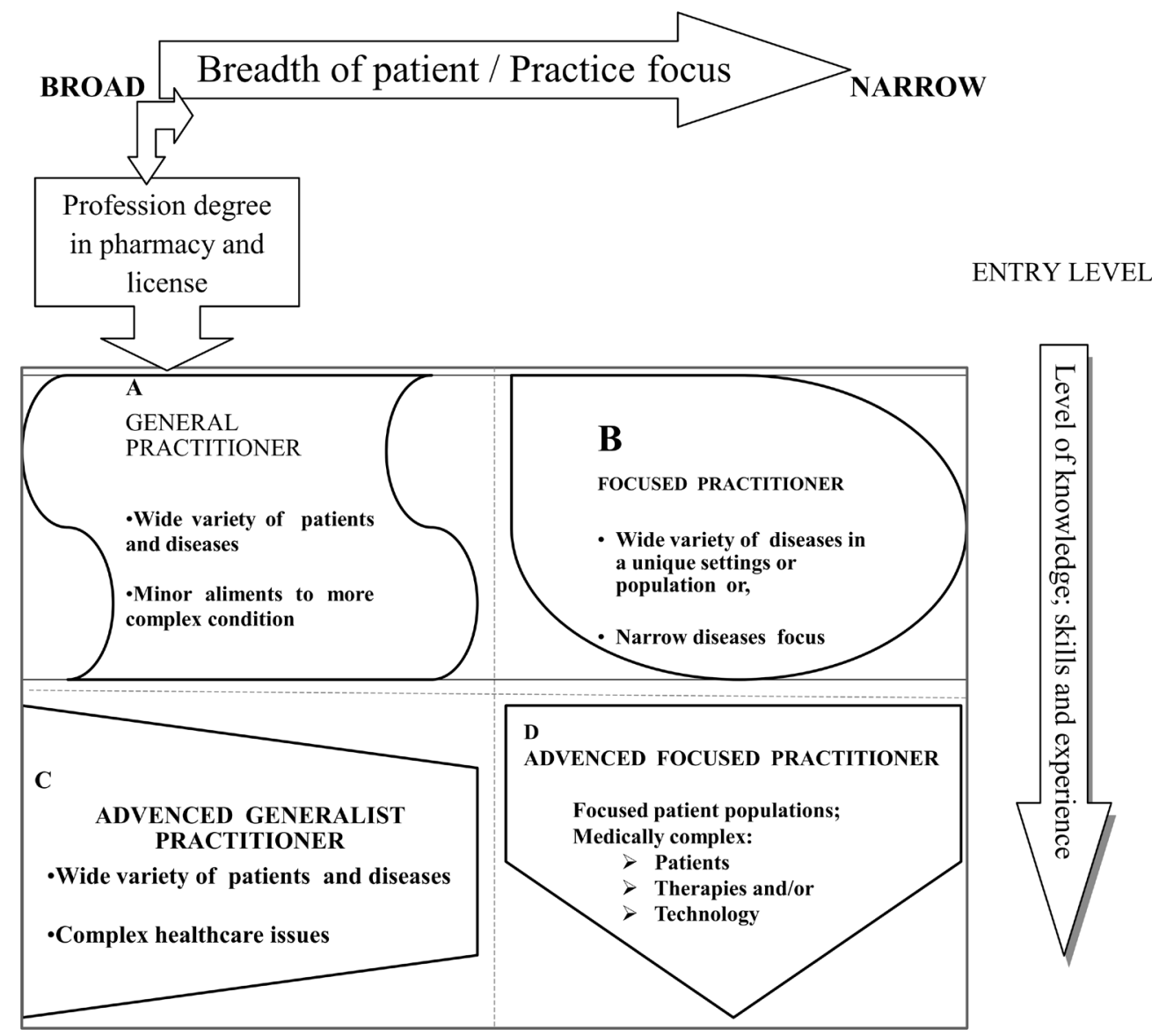

ADVANCE

Figure 2. Practitioners in direct patient care. 
specialty. Infectious Diseases and Cardiology are the two added qualifications for the pharmacotherapy specialty currently recognized by BPS. Pharmacists who wish to retain BPS certification must be recertified every seven years.

\section{Non- specialty certification}

For example, to become certified by CCGP, candidates are expected to be knowledgeable about principles of geriatric pharmacotherapy and the provision of pharmaceutical care to the elderly. Pharmacists who meet CCGP's requirements are entitled to use the designation Certified Geriatric Pharmacist, or CGP. Pharmacists who wish to retain their CGP credential must recertify every five years by successfully completing a written examination.

\section{Disease management certification}

NISPC offers certification in the management of diabetes, asthma, dyslipidemia, and anticoagulation therapy. To be certified by the NISPC, a pharmacist must pass an examination with questions that are specific to the specialty area, developed by experts, and designed to address four different areas of competency expected by all pharmacists who provide disease state management services to patients. There are no practice experiences or clinical training requirements in the specialty area. After passing the exam, pharmacists may use the designation of certified disease manager (CDM). Recertification is required every 3 years and is based on completion of 30 hours of CE in the specific disease state.

Also, multidisciplinary certification programs are available to professionals from many health disciplines, including pharmacists. Areas in which such certification is available include diabetes education, anticoagulation therapy, pain management, and asthma education. Table 5 shows post-licensure certifications and where they typically apply to pharmacists in narrowly focused and/or advanced areas of practice.

\section{Relationship between the scope of a pharmacist's prac- tice and credentials and post-licensure education and training}

Figures bellow (Figures 2, 3 and 4) present a framework for credentialing in pharmacy and summarize the elements (CCP, 2009). The framework attempts to illustrate: (1) how a pharmacist's career may evolve or progress after completion of initial professional education, licensure, and entry to practice; (2) the post-graduate education and training activities and certifications undertaken by pharmacists; and (3) the correlations between credentialing, broad competency areas, scope of practice, and patient populations served. Figures 2, 3 and 4 deal only with the patient care domain, corresponding with AACP CAPE Education-

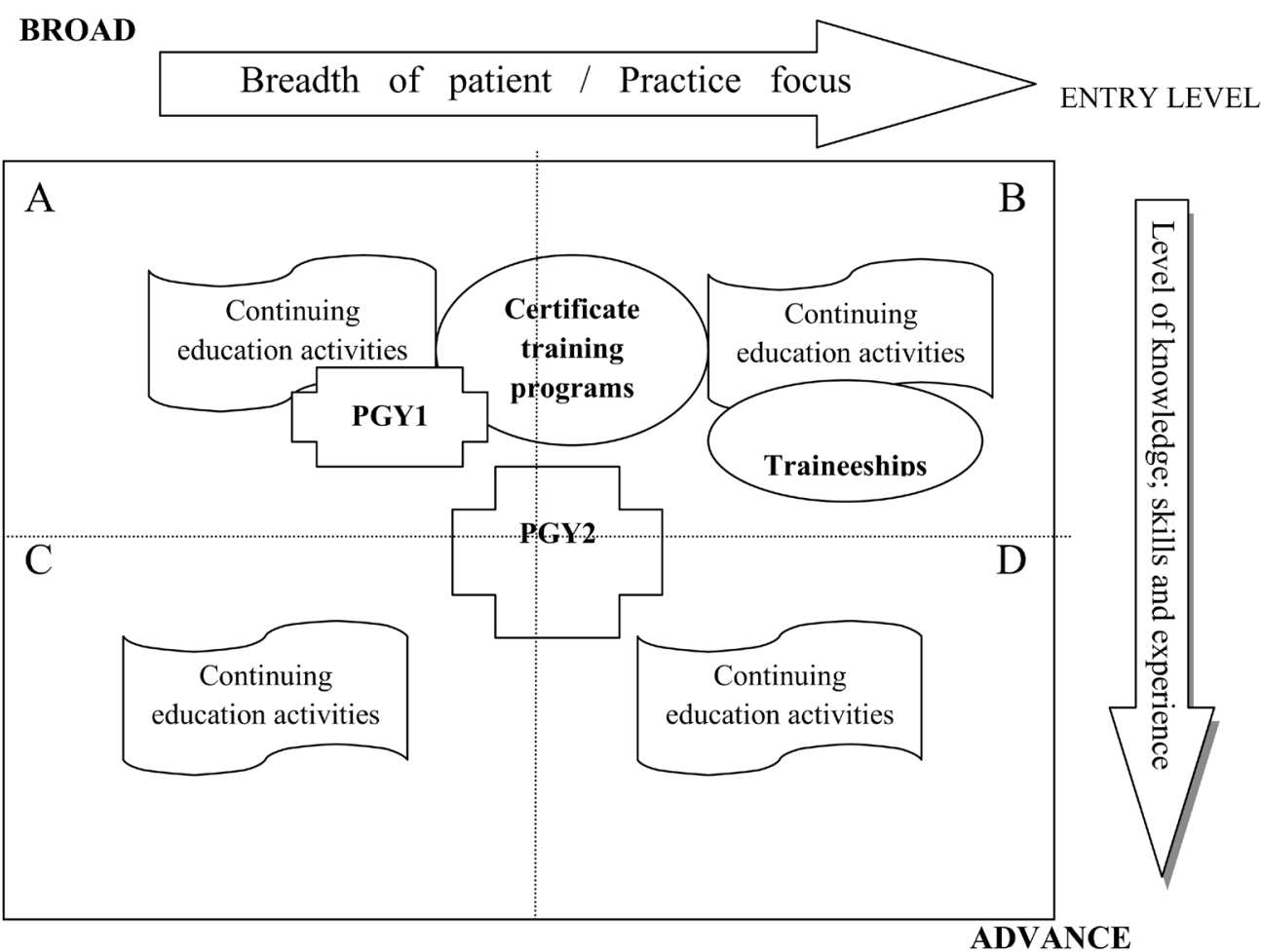

Figure 3. Post-licensure education and training relative to pharmacy practice. 
al Outcome \#1. However, Outcomes \#2 and \#3 are not included in the schematic presentations (CCP, 2009).

The surface A describes the practice of the community and hospital pharmacists. Surfaces B, C, or D reflects pharmacists professional development in a specific way. For example, pharmacists who choose to narrow their patient or practice focus (e.g. in diabetes or geriatrics) will move to surface B; pharmacists who elect choose to work with a broad base of patients and diseases, but also wish to substantially advance their level of knowledge, skills, and experience will move to surface C. An example of a pharmacist in this quadrant would be a pharmacotherapy specialist. Pharmacists in surface D have both narrowed their patient/practice focus and substantially advanced their knowledge and skills. An example of an Advanced Focused Practitioner would be a Board Certified Oncology Pharmacist (BCOP), one of the recognized specialty credentials in the pharmacy profession.

Figure 3 illustrates the range of post-licensure education and training activities pharmacists engage in to maintain their professional competencies and to support their continuing professional development.

Pharmacy practice residencies-(PGY1) provide training for generalists in hospitals, health systems, managed care, or community settings; hence their illustration is in Quadrant A in Figure 3. Specialized pharmacy practice res- idencies (-PGY2) residencies provide advanced training in a focused area of patient care. Traineeships, on the other hand, are more focused and would typically be undertaken by pharmacists with a narrower patient/practice focus (Quadrant B). Certificate Programs, which focus on the development of professional skills and their application in practice, would typically be undertaken by pharmacists in Quadrants A and B.

\section{Continuing Professional Development (CPD)}

The Institute of Personnel and Development (IPD, UK) launched an early definition of CPD in October 1997: CPD is systematic, ongoing, self-directed learning. It is an approach or process, which should be a normal part of how you plan and manage your whole working life. Of note, the definition of CPD adopted by the National Health Service (NHS) in Great Britain, in 1999, makes reference to patients and healthcare outcomes:

CPD is a process of lifelong learning for all individuals and teams of individuals which meets the needs of patients and delivers the health outcomes and healthcare priorities of the NHS and which enables professionals to expand to fulfill their potentia.

In 2002, the concept of CPD was described by FIP as: The responsibility of individual pharmacists for systematic

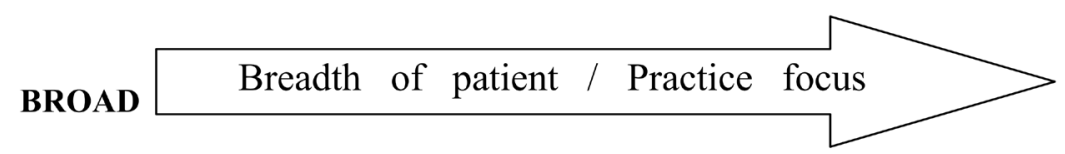

ENTRY LEVEL

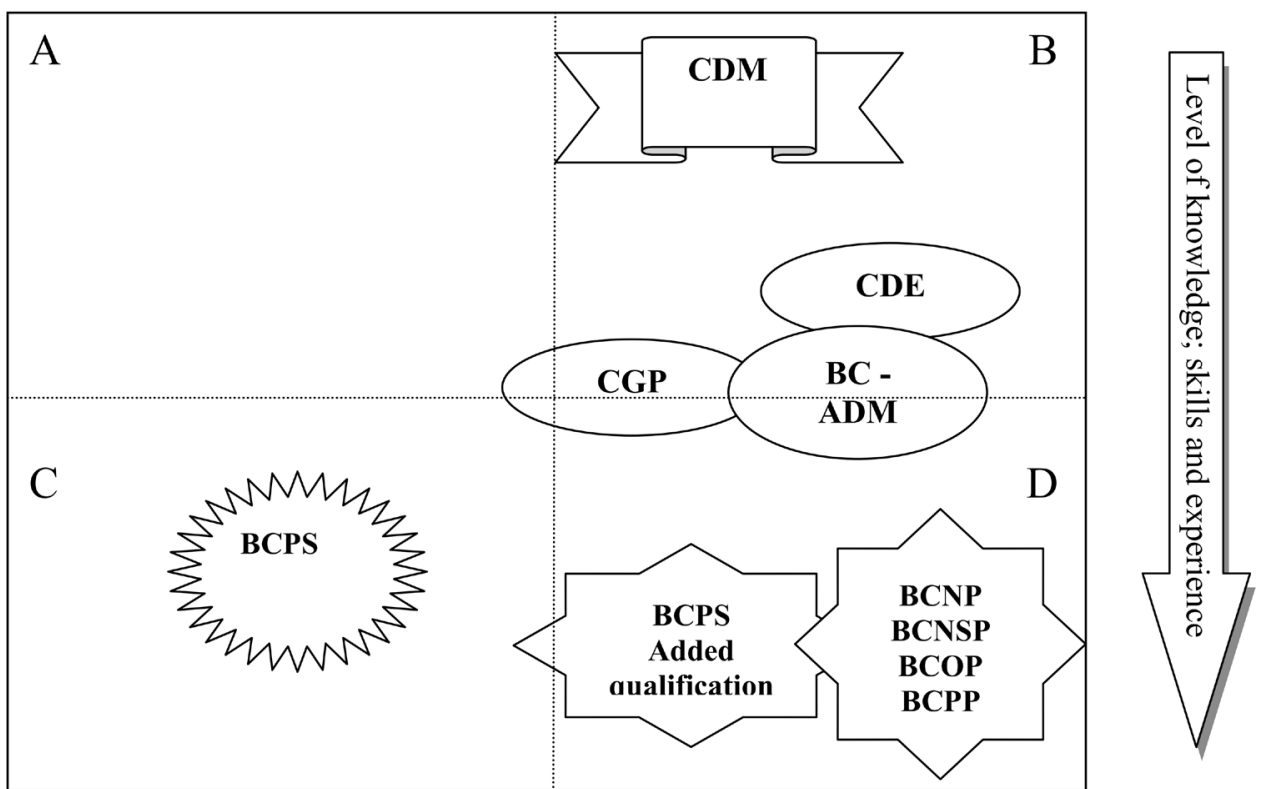

ADVANCE

Figure 4. Post-licensure certifications and where they typically apply to pharmacists in narrowly focused and/or advanced areas of practice. 
maintenance, development and broadening of knowledge, skills and attitudes, to ensure continuing competence as a professional, throughout their careers (FIP, 2002).

The same year, at a conference on lifelong learning, the following definition was offered:

Postgraduate professional education involving a cycle by which individual practitioners assess their learning needs, create a personal learning plan, implement the plan, and evaluate the effectiveness of the education intervention as it applies to their pharmacy practice (Hanson, 2002).

ACPE recent statement regarding CPD is that the CPD model provides the opportunity for quality improvement of the current system of continuing education, by building on the existing strong foundation of quality-assured, accredited continuing education for pharmacists (ACPE, 2003). The JCPP supports the concept of strong commitment to develop and maintain standards and programs to assure the public, governmental agencies, major employers and other influential organizations that pharmacists would maintain appropriate competencies throughout their careers.

The NAPB in NABP RESOLUTION NO.99-7-03 TITLE (NABP, 2003): Continuing Pharmacy Practice Competency resolved that NABP endorse and encourage structured programs of continuing professional development. Hence, NABP encourage colleges, faculties, and schools of pharmacy and boards to collaborate on providing seminars to further pharmacist continuing professional development; the boards of pharmacy encourage, endorse, and support the efforts of NABP, the ACPE, and the AACP to instill and perpetuate the concepts of continuing professional development in students and pharmacists.

The AACP supports the concept of CPD, so AACP work actively with ACPE and other pharmacy organizations in exploring methods for facilitating its use within pharmacy (AACP, 2003).

All these definitions and statements clearly indicate that pharmacists have an ethical obligation and responsibility for their own lifelong learning, and the maintenance of the knowledge, skills, attitudes and abilities necessary to deliver professional services in line with accepted, contemporary professional standards and public expectations. Since the system of mandatory CE has shown that it does not provide a satisfactory degree of assurance that pharmacists are maintaining the level of competence adequate to meet public needs and expectations, the framework of CPD has been evolved as an agenda for lifelong learning.

However, CPD does not replace $\mathrm{CE}$, but quality-assured $\mathrm{CE}$ is an essential component of CPD.

The need for $C P D$ can be shortly summarized as follows:

- To ensure that pharmacists maintain (at an appropriate level) their knowledge, skills and competence to practice throughout their careers in their own specific (or current) area of practice;

- To improve the pharmacist's personal perfor- mance (i.e., develop knowledge and skills);

- To enhance the pharmacist's career progression

Besides, CPD is based on principles as follows (Picton and Brackley, 1999)-

- $\mathrm{CPD}$ is a systematic, ongoing cyclical process of self-directed learning;

- It includes everything that practitioners learn, which enables them to be more effective as professionals;

- CPD includes the entire scope of the practitioner's practice, and may include activities both within and outside the usual work setting;

- CPD is a partnership between the practitioner and his or her organization, meeting the needs of both;

- The practitioner is responsible for his/her own professional development. The organization has a responsibility to help the practitioner meet the development needs that relate to performance in his/her current job

When considered together with the NHS definition given earlier, three important features of CPD are clear: $\mathrm{CPD}$ is practitioner-centered and self-directed; CPD is designed to be practice-related; CPD is outcomes-oriented in terms of maintaining competence, the professional development of the practitioner, meeting individual and organizational goals, and achieving improved patient outcomes. CPD has been described using four-stage and fivestage cycles (Figure 5).

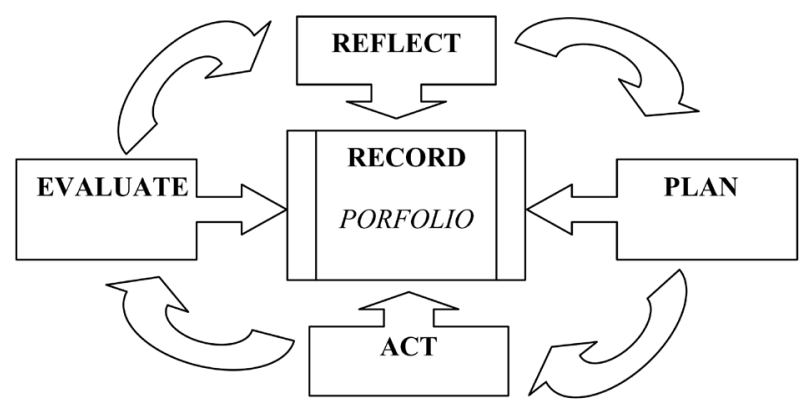

Figure 5. CPD process source CPP 2004

Reflect: referred to as "self-appraisal" or "assessment," this stage entails the pharmacist reflecting on personal and organization needs and goals for professional development, and self-assessing his/her knowledge, skills and competence. Reflection is important to learning; it has been defined as the complex and deliberate process of thinking about and interpreting an experience in order to learn from it. (Boud, Keogh and Walker,1985).

Plan: involves the design of a personal development plan (PDP). The plan includes all the activities that will address the identified learning and development needs and goals. The outcomes should be linked to one or more spe- 
cific professional competencies (ACPE, 2003). The plan could include structured programs (such as accredited CE), as well as a diverse range of informal learning activities, many of which will be work-based or work related (Figure 6).

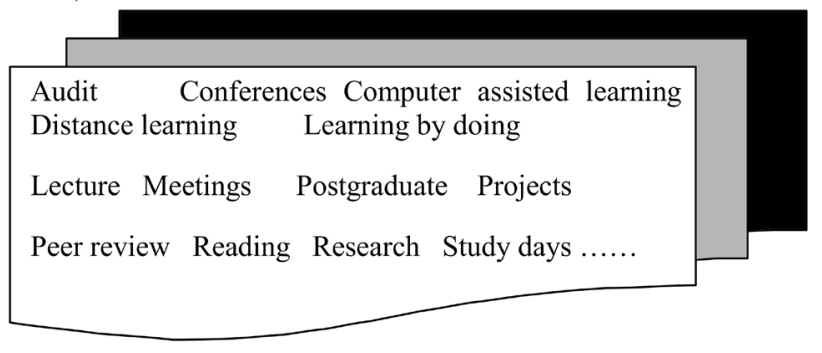

Figure 6. The PDP is recorded in the personal portfolio. Each pharmacist's situation is unique, so no two sets of learning needs and personal plans will be the same.

Act: putting the plan into action is the next well known stage.

Evaluation: can be carried out by the individual practitioner, by the practitioner's peers, or by the practitioner's supervisor or manager. In some CPD models (for example, in the UK), the portfolio is subject to review by the regulatory body. For example, in Ontario, Canada there is the opportunity for small-group peer review of the learning portfolio, and also for direct assessment of knowledge and skills. Some form of third-party review or evaluation of the portfolio would appear to be valuable, not only to provide feedback to the pharmacist, but also as a means to identify those that may be experiencing difficulty in one or more aspects of CPD, and in need of assistance or remediation, and to protect society from the few practitioners who otherwise would not self-assess and correct deficiencies. Feedback from third parties should be given in a constructive and non-threatening way, with the primary objective being to help the individual move forward in his/her professional development.

Record: central to the CPD cycle is the practitioner's personal portfolio, which becomes a comprehensive record, like a professional diary or transcript covering all the stages. The portfolio, which can be electronic or paperbased, should be readily accessible, and simple to use. Ideally, a standardized format should be adopted to facilitate training, data entry and, where applicable, portfolio evaluation. In CPD portfolios, pharmacists record all relevant learning experiences (accredited-CE or informal workbased) or work related activities. In time, the pharmacist's portfolio will develop into a comprehensive record of education and practice with multiple possible applications.

CPD is based on the above mentioned principles and adopts educational strategies that have proven to be effective. It potentially offers a quality improvement to the current systems for pharmacist CE. While an appropriate, competency-based education can prepare a pharmacist to enter practice, no professional program can provide or develop all the aspects of the knowledge, skills, attitudes and abilities that a pharmacist will ever need. These require a combination of an appropriate pre-service educational foundation, in-service training, hands-on work experience, and lifelong learning. For professionals, there is no doubt that education is a continuum. As acknowledged, the educational strategies, and the competency and outcomes based approach that are successfully utilized for pre-service training must be maintained throughout the practitioner's career. For all above mentioned, the state boards of pharmacy are requested, and expected, to protect the public by ensuring, through regulation, that licensed pharmacists are competent to deliver pharmacy services, as professionals.

\section{Conclusion}

As anticipated, due to the dynamic and intensely developing healthcare environment in the past several years, the pharmacist's role has dramatically changed from that of conventional compounder and dispenser to one of "drug therapy manager". The latter comprehensive role of the pharmacist involves spectrum of new responsibilities and best practice services to ensure that wherever the drug therapy is concerned, the best quality products to be selected, procured, stored, distributed, dispensed and properly administered in a manner so as to contribute to the health of patients with the risk reduced to the minimum for the patient. Now, the scope of pharmacy practice is more focused on patientcentered care, with all the cognitive functions of counseling, providing drug information and specific issues related to the managing and monitoring drug therapy. Pharmacists need to maintain their professional competence throughout their careers in order to provide safe, effective and quality professional services to patients and achieve the most positive patient outcomes possible. Schools of pharmacy prepare their graduates to acquire the necessary and rational competencies to enter practice, but the ongoing professional program can also provide or develop knowledge, skills, attitudes and abilities that a pharmacist will need in practice. Only a combination of an appropriate educational foundation, in-service training, hands-on work experience, lifelong learning, training and ongoing licensure, certification and evaluation of competencies will assure professional competence. Particularly noteworthy aspect about continuing professional development is that it can further engage pharmacists as adult learners, and enhance the overall effectiveness and outcomes of continuing education. Creating models for professional development provides the opportunity for quality improvement of the current system of continuing education, building on the existing strong foundation of qualityassured, accredited continuing education for pharmacists.

Health care systems, more stringent regulations and the existing oversight programs of licensure and certification agencies have the obligation to assure the public of the 
safety and quality of health care, including the pharmaceutical care. It is of paramount importance and great responsibility of each individual pharmacist to determine whether a higher standard is required in any area relating to their individual professional practice. And, finally, pharmacists as health care professionals have to commit themselves to lifelong learning, in order to remain current and proficient as the science base for medicine continues to evolve and become more complex.

There is no doubt, that the models of professional competences, credentialing and continuing professional development in pharmacy exist in many worldwide countries intending to promote consistency and uniformity in the delivery of professional services. However, the US model deserves special attention owing to its comprehensive approach and advanced practical solutions.

\section{Appendix}

AACP American Association of Colleges of Pharmacy

AACP is a national organization representing pharmaceutical education in the United States. Their mission is to represent and advocate all segments of the pharmaceutical academic community.

www.aacp.org

\section{AAPT American Association of Pharmacy Technicians}

AAPT provides continuing education and services to help technicians update skills. They also represent member's interests to the public as well as health care organization.

www.pharmacytechnician.com

\section{ACA American College of Apothecaries}

ACA is a research and education resource center that provides pharmacist with therapeutic information and other issues affecting the pharmacy profession. They also provide an inquiry support line, specialty practice education program, pharmacy-related publications, and current events in health care.

www.acainfo.org

\section{ACCP American College of Clinical Pharmacy}

ACCP it provides pharmacists the leadership, education, and other resources needed in clinical practice and research. They support and promote research training and educational programs in pharmacotherapy.

www.accp.com

AFPE American Foundation of Pharmaceutical Education

This foundation supports pharmacists to further their studies in advanced pharmaceutical science in industry, association work, academia, and other areas of professional practice. This foundation also provides high standards in education in colleges of pharmacy and American pharmacy through the support of ACPE, special programs of the
AACP, and other key projects. www.afpenet.org

AMCP Academy of Managed Care Pharmacy

AMCP is a professional society, dedicated to promote the development and application of pharmaceutical care, to ensure appropriate health care outcomes for all patients. This association also provides for its members the leadership, and support in managed care.

www.amcp.org

APhA American Pharmacists Association

This association provides professional information and education for pharmacists. It also advocates a pharmacist to improve healthcare of patients through the provision of comprehensive pharmaceutical care.

www.aphanet.org

ASAP American Society for Automation in Pharmacy

This organization aids its members in applying computer technology into pharmacy. Members include independent pharmacies, hospital pharmacies, colleges of pharmacy, state boards of pharmacy, state and national associations and government agencies.

www.asapnet.org

ASCP American Society of Consultant Pharmacists

ASCP is an international pharmacy association for consultant pharmacists specializing in senior care. The association provides for it members leadership, education and resources needed for the practice of pharmacy in senior care.

www.ascp.com

ASHP American Society of Health-System Pharmacists

ASHP is a professional association that represents pharmacists who practice in hospitals, health maintenance organizations, long-term care facilities, home care, and other components of health care systems. Their main goal is to assist pharmacists to make the best use of medicine.

www.ashp.org

ASP Academy of Students of Pharmacy

ASP is the student section of APhA and it represents pharmacy and pre-pharmacy students in the United States and Puerto Rico. Its mission is to be the voice of pharmacy students and to prepare them to be professionals who provide and promote pharmaceutical care.

www.aphanet.org (Student page)

ASPEN American Society for Parenteral and Enteral Nutrition

ASPEN is a professional organization whose members are involved in the provision of clinical nutrition therapies, including parenteral and enteral nutrition. It prepares standards and guidelines for the use of nutrition support and 
professional practice. This agency also works with other nutrition, health care organizations, government agencies and insurance providers to offer patients the optimal use of nutrition therapies.

www.nutritioncare.org

ASPL American Society for Pharmacy Law

The purpose of this organization is to further the legal knowledge of pharmacists, students of pharmacy, students of law, attorneys, government, and other professions interested in legal issues affecting pharmacy and medication related issues. The agency also communicates accurate legal information to attorneys and pharmacists, educates pharmacists to their rights, distributes information, and provides forums.

www.aspl.org

BPS Board of Pharmaceutical Specialties

This organization trains and certifies pharmacists in a specialized field. Fields such as nuclear pharmacy, nutrition support pharmacy, oncology pharmacy, pharmacotherapy, and psychiatric pharmacy.

www.bpsweb.org

CCCP Canadian College of Clinical Pharmacy http://www.ccep.ca/

CCGP Commission for Certification in Geriatric Pharmacy

CCGP is a national certification program for pharmacists who want to specialize in geriatric pharmacy practice. They are also responsible for establishing eligibility criteria to take the Certification Examination in Geriatric Pharmacy and establishing program policies.

www.ccgp.org

CCP Council of Credentialing in Pharmacy

This organization provides leadership, standards, public information, and coordination for the profession's voluntary credentialing programs. Their goal is to provide credentialing programs in pharmacy that meet the established standards and quality.

www.pharmacycredentialing.org/default.htm

CPF Community Pharmacy Foundation

$\mathrm{CPF}$ is an organization with a primary purpose to assist community pharmacists by encouraging and fostering improvements in patient care. They also support efforts of pharmacist intervention in achieving targeted therapeutic goals.

www.tcpf.org

CPNP College of Psychiatric and Neurologic Pharmacists

CPNP is a professional membership association that represents pharmacists involved in the pharmaceutical care of psychiatric and neurologic patients. CPNP's main goal is to assist pharmacists as they work to apply evidencebased, cost efficient best practices in achieving patient recovery and improved quality of life. www.cpnp.org

FIP International Pharmaceutical Federation

This organization represents both pharmacists and pharmaceutical scientists worldwide. Its main purpose is to educate and the development of the practice and science of pharmacy.

www.fip.org

IACP Institute for the Advancement of Community Pharmacy

This institute supports educational initiatives, research projects and programs to enhance community pharmacy practice in the United States. IACP also promotes the value of community pharmacists and pharmacies

www.advancepharmacy.org

JCPP Joint Commission of Pharmacy Practitioners

JCPP was established to serve as a discussion forum for the CEOs and elected presidents of all major national pharmacy practitioner organizations. There are full members (AMCP, ACA, ACCP, APhA, ASCP, ASHP, and NCPA) and liaison members (AACP, ACPE, NABP, and NCSPAE). JCPP meets four times per annum.

NABP National Association of Boards of Pharmacy

NABP is an association that is committed in enforcing uniform standards, jurisdictions and assisting board members nationally and internationally. This association spans from the United States, Guam, Puerto Rico, New Zealand, eight Canadian Provinces and four Australian states.

www.nabp.net

NACDS National Association of Chain Drug Stores

The chief purpose of this association is to represent the views and policy positions of member chain drug companies. This is accomplished by various programs, services, and issues that the association is involved in.

www.nacds.org

NCPA National Community Pharmacists Association

This association represents pharmacist owners, managers, and employees of nearly 250,000 independent community pharmacies across the United States. Their goal is to represent the professional and proprietary interests of independent community pharmacists.

www.ncpanet.org

NCPDP National Council for Prescription Drug Programs

This organization's goal is to create and promote data interchange standards in pharmacy industry, provide information and resources to educate industry, and support the needs of their members. NCPDP brings together diverse leaders of industry and decision-makers to their annual 
conferences.

www.ncpdp.org

NCSPAE National Council of State Pharmacy Association Executives

This association represents each state's organization in providing business and professional development material, continuing education for pharmacists, pharmacy students, and pharmacy technicians and various other membership services.

www.ncspae.org

NIPCO National Institute for Pharmacist Care Outcomes The national accrediting organization for pharmacist care education and training programs leading to the pharmacist care Diplomate credential.

www.nipco.org

NPhA National Pharmaceutical Association

The purpose of this organization is to represent the interests and needs of minority pharmacists in all practice settings. NPhA is also interested in advancing the standards of pharmaceutical care among all pharmacists.

www.npha.net

\section{NPRT National Pharmacists Response Team}

This organization purpose is to prepare pharmacists, pharmacy students, and pharmacy technicians that are interested in counteracting any possible terrorist attacks. Individuals trained will be called upon to assist in a mass vaccination or chemoprophylaxis campaign.

www.aphanet.org/pharmcare/NPRTPage.htm

NPTA National Pharmacy Technician Association

NPTA is an organization for pharmacy technicians. Its stated mission is to help enhance, promote, and enrich the lives and careers of every pharmacy technician. Its vision is to provide unmatched education and support for pharmacy technicians around the world.

www.pharmacytechnician.org

PhRMA Pharmaceutical Research and Manufacturers of America

This organization represents the country's leading research-based pharmaceutical and biotechnology companies. It also supports young scientists in the pharmaceutical industry by awarding them with fellowships and grants at critical decision points of their career.

www.phrma.org

\section{PTCB Pharmacy Technician Certification Board}

PTCB is a nonprofit organization that oversees the certification program of pharmacy technicians in all practice settings. This organization develops the education and the exams for certification.

www.ptcb.org
PTEC Pharmacy Technician Educators Council

PTEC is an association representing pharmacy technician educators. Its primary mission is to assist the profession of pharmacy in preparing high quality well-trained technical personnel through education and practical training.

www.rxptec.org

SNPhA Student National Pharmaceutical Association SNPhA was founded in 1972 as an extension of NPhA to pharmacy students. This association is educates and services students concerned about pharmacy services, professional development, and the lack of minority representation in pharmacy and other health related professions.

www.snpha.com

\section{References}

AACP,2003.(http://www.aacp.org/Docs/AACPFunctions/ Structure/5445_OfficialHOdMinutes03.pdf), accessed 2007.

AACP, 2004. Educational Outcomes 2004. Alexandria, VA.Center for the Advancement of Pharmaceutical Educational Outcomes (http://www.aacp.org), accessed 2004.

ACPE, 2001. Strategic plan 2001. Chicago, IL (http://www.acpeaccredit.org/pdf/ACPEplan.pdf), accessed 2004.

ACPE, 2003. Definition for Continuing Education, Chicago, IL (http://www.acpe-accredit.org), accessed 2007.

ACPE, 2003. Statement on Continuing Professional Development (http://www.acpeaccredit.org/pdf/ACPE\%20Statement $\% 20$ on\%20CPD\%20Sept\%202003.pdf), accessed 2007.

ACPE, 2006. Accreditation Standards and Guidelines for the Professional Program in Pharmacy Leading to the Doctor in Pharmacy Degree. Standards for Curriculum, Standard No 9, The Goal of the Curriculum and Standard No12, Professional Competencies and Outcome Expectations (https://www.acpe-accredit.org), accessed 2008.

APhA, 2007. Code of Ethics for Pharmacists (www.aphanet.org), accessed 2008.

Boud, D., Keogh, R., \& Walker, D., 1985. What is Reflection in Learning?, in: D. Boud, R. Keogh, \& D.

Walker (Eds.), Reflection: Turning Experience into Learning London: Kogan Page, pp. 7-17.

CAC, 2001. Measuring, continuing competence of Health Care practitioners: Where are we now-Where are we headed? (http://www.citizenadvocacycenter.org/), accessed 2006.

CCP, 2001. White Paper: Credentialing in Pharmacy. Am. J. Health Syst. Pharm. 58(1), 69-76

CCP, 2004. Resource Document. Continuing Professional Development in Pharmacy. (http://www. pharmacycredentialing.org/), accessed 2008.

CCP, 2006. Credentialing in Pharmacy (http://www. pharmacycredentialing.org/), accessed 2008.

CCP, 2009. Scope of Contemporary Pharmacy Practice: Roles, Responsibilities, and Functions of Pharmacists and Pharmacy Technicians (http://www.pharmacycredentialing. org/), accessed 2009.

ECD (European Commission Definition), 2003 (http://www. ibeeurope.com/Database/Factsheets/F0521lifelong.htm), accessed 2007. 
Fenichel,R.,2004. Which drugs should be available over the counter? Br. Med J. 329, 182-3.

FIP, 2002. Statement of Professional Standards on Continuing Professional Development. The Hague, The Netherlands (http://www.fip.org/pdf/CPDStatement.pdf), accessed 2006

Greiner, AC., Knebel, E., 2003. Health Professions Education: A Bridge to Quality, The National Academies Press, Washington, DC, pp.45-74

Hanson,A., 2002. Fifth Lifelong Learning in Pharmacy Conference, Rhodes University, Grahamstown, South Africa. PJ 269 (7209) 171-173.

JCPP, 2004. Future vision of pharmacy practice; Joint Commission of Pharmacy Practitioners; http:// www.ascp.com; August 2004; accessed, 2007.

Kaplan,W., Laing, R., 2004. Priority Medicines for Europe and the World, WHO, Department of essential drugs and Medicines Policy, pp117-129

Maine, LL., 1998. Pharmacy Practice Activity Classification. J. Am. Pharm. Assoc. 38(2), 139-48.

Miller, G.E., 1990. The assessment of clinical skills/competence/ performance. Acad. Med.(Supplement) 65, S63-7

NABP, 2003. Resolution 99-7-03 (http://www.nabp.net), accessed 2007.

NABP，2005. (http://www.nabp.net/news/nabp-launches-psamnon-punitive-knowledge-evaluation-tool-for-pharmacists/), accessed 2007.

NABP, 2006. Model State Pharmacy Act and Model Rules of the National Boards of Pharmacy (http://www.nabp.net/index. asp), accessed 2007.

NABP, 2006. NAPLEX Blueprint(http://www.nabp.net/ftpfiles/ NABP01/Updatedblueprintinfo.pdf), accessed 2007.

Newton, D.W., Boyle, M., Catizone, CA., 2008. The NAPLEX: Evolution, purpose, Scope and Educational Implications. Am. J. Pharm. Edu.72(2). Article 33.

Picton, C., Brackley., K. 1999. Using the medicines information framework to help continuing professional development (CPD) (http://www.ukmi.nhs.uk/Policy_product/ Documents/ContinuingProfessional\%20Development 1 . pdf), accessed 2004.

Savery, J.R.,2006. Overview of Problem-based Learning: Definitions and Distinctions The Interdisciplinary Journal of Problem-based Learning, 1(1) pp.9-20

Sheaffer, L.S., 2004. Pharmacist credential and accreditation of pharmacy programs, in: Peterson, AM., Managing Pharmacy Practice, Principles, Strategies, and Systems.CRC Press, LLC, pp.369-395

Swankin, D., LeBuhn, A., Morrison, R., 2006. Implementing Continuing Competency Requirements for Health Care Practitioners. CAC (http://www.citizenadvocacycenter.org/), accessed 2007.

WHO, 2006. Developing pharmacy practice. A focus on patient care. World Health Organization Department of Medicines Policy and Standards Geneva, Switzerland In collaboration with International Pharmaceutical Federation, The Hague, The Netherlands (Eds.).

Резиме

\title{
Професионални компетенции, квалификации и континуиран професионален развој во фармацевтската професија - Модел рамка за фармацевтска грижа насочена кон пациент -
}

\author{
Рената Славеска Раички ${ }^{1}$ Василка Нича² и Татјана Кадифкова Пановска ${ }^{1}$
}

\author{
1 Фармацевтски Факултет, Универзитет “Св Кирил и Методиј”, Скопје \\ 2 Јавна Институиија во Здравствен сектор, за потребите на ПХИ Универзитетски Клиники, Институти и \\ Ургентен Центар, Скопје
}

Клучни зборови: фармацевтска професија, компетенции, квалификации, континуиран професионален равој, фармацевтска грижа насочена кон пациент

Во текот на изминатата декада, улогата на фармацевтската професија претрпува суштински промени. Сите промени се развивани и усвојувани на еден систематичен начин од аспект на унапредување на квалитетот на професијата. Воопшто, професионалните и националните авторитети, ширум светот, се посветени на развојот на професионалните компетенции, квалификации и континуираниот професионален развој за да се нагласи одржување на високи стандарди за професионален развој и како одговор на промените што се случуваат во фармацевтската едукација и националните здравствени политики. Постојаното унапредување во контекст на здравствената регулатива за секоја земја, во иднина, ќе го обликува прогресот на овој процес.

Овој труд дава преглед на постоечките концепти за професионалните компетенции, квалификации и континуиран професионален развој во фармацевтската професија со цел да се воочи и објасни комплексноста присутна во овој опсежен домен. Исто така, може да послужи како платформа за соработка на локално ниво за бројни авторитети од здравствениот домен. 


\title{
Testing for drug and alcohol abuse at the workplace
}

\author{
Zoran Kavrakovski*, Katerina Jugreva, Biljana Bauer - Petrovska \\ Faculty of Pharmacy, University of "Ss Cyril and Methodius", Skopje, Republic of Macedonia
}

Received: November 2009; Accepted: December 2009

\begin{abstract}
Drug and alcohol abuse in the workplace represents a great risk to employee's health and safety. More than $50 \%$ of the employees worldwide are related to easily accessible drug abuse, while $70 \%$ of the employees are related to alcohol abuse in the workplace. Tests for detecting drug and alcohol abuse in the workplace should be part of a new regulation, compulsory for all employees in the Republic of Macedonia. Implementing this sort of testing program should at the same time be a step towards devising particular solutions that shall bring about greater safety in the working environment. A key element in the implementation is to devise and establish an adequate policy that shall determine the risk factors within a working establishment which shall clearly express its position regarding drug and alcohol abuse during working hours. Along with the risk factors, the policy may also include the program for testing both, employees and the ones who are about to be employed, for drug and alcohol abuse. In order to implement this sort of test, it must be in accordance with the Occupational Safety and Health Act (Official gazette of the Republic of Macedonia, $N^{o}$ 92/07, 2007) and a legal framework has to be defined, that shall regulate and solve numerous aspects of this issue, in order to fully implement the program for drug free working environment pursuant to the Declaration and the decrees of the United Nations General Assembly in 1998.
\end{abstract}

Key words: drugs and alcohol abuse, workplace, employees, drugs and alcohol testing.

\section{Introduction}

Drugs and alcohol are a plausible and definite risk for the employees' safety in the work environment (Ghodse, 2005). The abuse of alcohol and drugs can occur in any workplace. According to the statistics more than $50 \%$ of employees worldwide are connected with misuse of readily available drugs and $70 \%$ of them with alcohol abuse in the workplace (Bennett, Lehman, 2000). The abuse of alcohol and other drugs may damage both, the physical and the mental health (Commission for Occupational Safety and Health Act, MIAC, 2008). The impairment of behavior can result in increased risk of injury or harm (Drug \& Alcohol Information Centre, 2007) and this kind of abuse can also affect employees' productivity, safety and security, decision making, morale, as well as the organizational image and the community relations (Breugem et al., 2006).

zoka@ff.ukim.edu.mk
In the Republic of Macedonia testing for drug and alcohol abuse in the workplace should be a new legal regulation, mandatory for all employees. The introduction of the drug testing program should at the same time be an introduction to the process of solution making that will signify greater safety in the workplace. The Poison Control Center (PCC) (together with the toxicological laboratory) should be the carrier of the activities related to drug testing at the workplace as well as in developing new programs for testing, control and education that can help employers cope with this kind of issues.

\section{Considerations before conducting a drug testing program}

The first step in the risk management process is identifying hazards and hazards factors. When assessing whether alcohol and other drug use poses a safety and health hazard at the workplace, a range of factors should be considered. At some workplaces, the hazards associated with al- 
cohol and other drugs may be greater due to the nature of the workplace. Hazards or hazard factors that are important to consider in relation to increased risk of injury or harm if workers are impaired by alcohol or other drugs include operation of machinery, driving in the course of work, situations where concentrations or motor coordination is relied on to carry out a job, use of hazardous substances and performing duties as part of a team. Even when people return a zero alcohol or drug level they may still be impaired by the "hangover" effects that can last beyond the direct presence of the drug and create risks. The hazards and risks associated with alcohol and drug use at the workplace should be assessed in the same way as other occupational safety and health issues (Work Cover Corporation of South Australia, 2006).

According to the Occupational Safety and Health Act, (Official gazette of the Republic of Macedonia, $N^{\circ}$ 92/07, 2007), and according to other supporting regulations there is no specific reference to alcohol and other drugs. The solution is all parties at the workplace to comply with their general "duty of care" in relation to usage of alcohol and other drugs and their potential acute and chronic effects regarding safety and health in the workplace. Also there are other legislations that a relevant to alcohol and drugs but to keep in mind that these legislations are closely connected to a specific social and working area (Work Cover Corporation of South Australia, 2006). In order to conduct a drug testing and to achieve a drug-free workplace, employers must develop drug-free workplace program. A comprehensive drug-free workplace program generally includes developing a drug-free workplace policy. The primary aim of the policy is to provide a clear documented guide regarding the workplace's stance on drug and alcohol issues in relation to the workplace and to define the role of the employees, supervisors and in dealing with alcohol and drugs related work issues (Hunter Centre for Health Advancement, 2000). The program also includes supervisor training, employee education, employee assistance and drug testing. Employers may choose not to include all five components but it is recommended to explore all of them while developing a drug-free workplace program. Research shows that more components may lead to a more effective program. However, because every business is unique, there is not only one way to establish a drug-free workplace program. In order to conduct a drug testing it is necessary to coordinate this component with the Occupational Safety and Health Act in which no specific provisions are related to alcohol and drug testing. As a result employers are enabled to choose whether to test if risk assessments show particular risk, unless their organization is subjected to certain federal laws (ex. transportation drug-testing regulations, or aviation drug-testing regulations and others), as well as to keep in mind that industries may have industry-specific legislations or codes that deal with alcohol and other drugs at the workplace and these should be referred to, and also the drug testing is a contentious area (Work Cover Corpo- ration of South Australia, 2006). It is recommendable for the employer before conducting any drug-testing program to have a written policy that clearly outlines the necessity for the drug-testing. Therefore employers should carry out risk assessment in order to establish the nature of the policies and programs according to the level of risk at the workplace.

\section{Testing for drugs and alcohol abuse at the workplace}

Drug and alcohol abuse in the workplace is an issue that poses great threat to employees health, safety and security. That is why analysis is essential. According to the Occupational Safety and Health Act (Official gazette of the Republic of Macedonia, $\left.N^{\circ} 2 / 07,2007\right)$, employers are obliged to undertake necessary measures regarding the health and safety of the employees. By doing this, the potential and specific dangers may be identified, resulting in taking proper actions for their on time elimination, isolation, as well as minimization of their influence.

The Poison Control Centre (PCC) may take part in developing certain measures and activities in order to help employers interested in the development and improvement of the programs for testing drug and alcohol abuse in the workplace, by organizing educational courses, workshops and providing advice regarding the benefits and the significance of the health and safety effects of these analysis in both, the working and the living environment.

For great deal of employers, the drug testing program as well as the alcohol testing program may bring about less absence from work, decline in team changes when working in shifts, improvement of the health, safety and morale of the employees, as well as increase in work efficiency and productivity.

\section{What is to be tested}

After conducting the drug-testing program different procedures can be carried out in order to test alcohols, cocaine, cannabinoids, designer drugs, prescribed medications not used for medical purposes (such as opiate analgesics, sedative hypnotics), inhalants, hallucinogens, narcotics and also active substances within the drug which have significant effect on CNS. The material that is to be tested includes different kinds of samples, preferably urine, saliva and hair which are less painful to collect as well as blood samples which represent a bit more painful procedure.

\section{Group of people to be tested and when to be tested}

The drug and alcohol testing in the workplace can be carried out not only on all new applicants before being employed in the service, but on the already employed ones as well. This is of great significance for employees in a workplace with high risk of injury or illness, as well as other 
job positions defined as high-risk and sensitive in terms of health and safety of the employees, their associates and customers. These job positions include the organic-chemical and oil industry, construction, aviation, tourism, transportation of passengers, technical and health care, police and military structures, working with dangerous and harmful chemicals, explosives, etc. The drug and alcohol abuse testing program shall be implemented in the following cases:

Pre-employment testing: drug and alcohol abuse affects the person's behavior, psychophysical ability, and work efficiency;

Post accident/incident testing: employees that have been directly involved in certain incidents must immediately undertake testing in order to discover whether the drug and/or alcohol abuse, as well as medicament abuse (with significant effect on the CNS) are the factors that affected the accident;

Intentional testing: employees are being tested due to suspicion of drug and/or alcohol abuse;

Periodic testing or random testing: all employees or a certain group of employees working at a high risk and safety-sensitive job position are being tested randomly, without being given previous notice. The testing may include:

- random selection of employees from a certain team; or

- $\quad$ testing each employee within a team, randomly selected, several times in a defined period of time.

Also, the testing may be performed on people (such as: suspended workers) who are involved in rehabilitation programs, once again by means of random choice in 12 to 24 months, in order to obtain better monitoring of the therapy efficiency. The decision for performing periodic testing on employees must be in accordance with the protection of privacy and human rights.

\section{Current position of the testing for drugs and alcohol abuse at the workplace in other countries}

According to other countries' stance (USA, Canada, Australia), the introduction of the alcohol and drug testing should be made in consultation with employees, an Occupational Health and Safety (OHS) representatives and union representatives. The drug testing can be introduced if a risk assessment has identified that there are risks involved in undertaking certain activities whilst under the influence of alcohol and other drugs. Privacy, confidentiality and the legal position of employees and management should also be considered. The alcohol and other drug testing should be implemented as part of a comprehensive alcohol and drug program with appropriate safeguards, clear policy and procedures, and provision of education and counseling. The alcohol and drug testing in the workplace should also be introduced if there are existing legislative provisions, such as those relating to rail safety workers, passenger transport workers and heavy vehicle drivers. There is also legislation prohibiting employees from working while intoxicated in the mining and aviation industries (Commission for Occupational Safety and Health Act, MIAC, 2008).

\section{Current position of the testing for drugs and alcohol abuse at the workplace in the Republic of Macedonia}

Currently, in the Republic of Macedonia the programs for drug and alcohol testing among employees are still a legal challenge. In order to implement a drug-free workplace program and be able to conduct testing for drugs and alcohol abuse at the workplace, it is necessary to establish a legal frame that covers many aspects. This can be achieved by imposing regulation that enables:

- implementation of the new safety strategy in the work environment;

- monitoring danger of hazards;

- conducting prevention, education, rehabilitation;

- clear definition of the rights and accountability of employees and employers;

Also it is very important to set rulebooks for proper and methodological collection of samples for detecting drugs and alcohol presence in urine and blood as well as to set rulebook for establishing referential values of some drugs and their metabolites in blood, urine, saliva hair etc.

\section{Conclusion}

A constructive step for employers to address alcohol and other drugs safety and health issues is to develop a workplace alcohol and other drugs policy, with supporting procedures, which address specific circumstances at the workplace. The development of a written policy and supporting procedures provides an opportunity to develop a range of management strategies designed to deal with issues that could arise. One important strategy for preventing problems is to provide information, education and training to all people at the workplace about the effects of alcohol and other drugs and their risks to safety and health, and the alcohol and other drugs policy and supporting procedures if developed. Providing information about alcohol and other drugs also contributes to the development of a workplace culture where workers are aware of the potential risks to safety and health and are prepared to encourage each other to work safely.

\section{References}

Bennett, J., Lehman,W., 2000. Preventing workplace substance abuse. Beyond drug testing to wellness. American Psychological Association Washington, DC.

Breugem, L. et al., 2006. The Impact of Alcohol and Other Drugs in the Workplace. SafeWork SA, 1-101.

Commission for Occupational Safety and Health Act, MIAC., 2008. Alcohol and other drugs in the workplace. Guidance 
Note, WA, 1-27.

Drug \& Alcohol Information Centre., 2007. Why worry about alcohol and other drugs in the workplace? Drug ARM National Office, Australasia, Brisbane, 1-4.

Ghodse, H., 2005. Addiction at work: tackling drug use and misuse in the workplace. Gower Publishing Ltd, UK.

Hunter Centre for Health Advancement., 2000. A guide for implementing a drug and alcohol policy in the workplace. NSW, 1-5.
Official gazette of the Republic of Macedonia, $N^{o}$ 92/07., 2007. Occupational Safety and Health Act.

Work Cover Corporation of South Australia., 2006. Alcohol and other drugs in the workplace. Guide to developing a workplace alcohol and other drugs policy. Work Cover Authority of NSW, Sydney, 1-28.

\title{
Резиме
}

\section{Испитување на злоупотребата на дроги и алкохол на работното место}

\author{
Зоран Кавраковски*, Катерина Југрева, Билјана Бауер - Петровска \\ Фармацевтски Факултет, Универзитет “Св. Кирил и Методиј” Скопје, Р. Македонија
}

Клучни зборови: злоупотреба на дроги и алкохол, работно место, вработени, тестирање на дроги и алкохол.

Злоупотребата на дрогите и алкохолот на работното место претставува голем ризик по здравјето и безбедноста на вработените. Повеќе од 50\% од вработените во светски рамки се поврзуваат со злоупотреба на лесно достапни дроги, а 70\% од нив со злоупотреба на алкохол на работното место. Испитувањата за злоупотреба на дрогите и алкохолот во работната средина треба да биде нова законска обврска, задолжителна за сите вработени во Република Македонија.

Воведувањето на програмата за испитување на оваа проблематика треба истовремено да биде и вовед во креирањето на одредени решенија кои ќе значат поголема безбедност во работната средина. Клучен елемент претставува креирањето и воспоставувањето на соодветна полиса каде преку утврдување на ризик факторите во работната установа јасно ќе се дефинираат нејзините ставови во однос на злоупотребата на дрогите или алкохолот во текот на работното време. Согласно ризик факторите, во полисата може да биде вклучена и програмата за испитување на дроги и алкохол кај вработените, како и кај лица кои допрва треба да се вработат. За да се спроведе ваквото испитување мора да постои усогласување со Законот за безбедност и здравје при работа (Службен весник на РM, бр. 92/07, 2007) и истовремено да се изготви и дефинира правна рамка со која ќе се регулираат и решат многу аспекти од оваа проблематика, сѐ со цел да се имплементира програмата за работна средина без дроги согласно Декларацијата и заложбите на Генералното собрание на Организацијата на Обединетите Нации (ООН) од 1998 година. 


\section{INSTRUCTIONS FOR AUTHORS}

Macedonian Pharmaceutical Bulletin is an official publication $\mathrm{f}$ the Macedonian Pharmaceutical Association. The journal publishes original scientific papers, short communications, reviews, mini-reviews and professional papers from all fields of pharmacy and corresponding scientific fields of interest for pharmacy (pharmaceutical and medicinal chemistry, immunology and imunochemistry, molecular biology, pharmaceutical analyses, drug quality control, pharmaceutical technology, pharmacoinformatics, pharmacoeconomics, biopharmacy, pharmacology, applied botany, pharmacognosy, toxicology, clinical pharmacy, food and nutrition, physical pharmacy, organical synthesis, social pharmacy, history of pharmacy etc.)

The Macedonian Pharmaceutical Bulletin, also, publishes and other contributions (recommendations and announcements, reports of meetings, important events and dates, book reviews, various rubrics).

\section{Types of paper}

Original scientific papers (full length manuscripts) should contain own unpublished results of completed original scientific research.

Short communications also should contain completed but briefly presented results of original scientific research. The article should be prepared as described for full length manuscripts, except for the following: the number of pages should not exceed 10 (including 2 illustrations, figures or tables). An Abstract should be included as well as a full reference list.

Reviews and mini-reviews are written at the invitation of the Editorial Board. "Mini-reviews" of a topic are especially welcome.

They should be surveys of the investigations and knowledge of several authors in a given research area, the competency of the authors of the reviews being assured by their own published results.

Professional papers report on useful practical results which are not original but help the results of the original scientific research to be adopted into practical use. Professional papers might be based on the elaborating of theoretical data

\section{Language}

Original scientific papers, short communications, reviews and mini-reviews should be written in good English (American or British usage is accepted, but not a mixture of these), while professional papers and all other contributions may be submitted in Macedonian.

\section{Submission declaration}

Submission of an article implies that the work described has not been published previously (except in the form of an abstract or as part of a published lecture or academic thesis), that it is not under consideration for publication elsewhere, that its publication is approved by all authors and tacitly or explicitly by the responsible authorities where the work was carried out, and that, if accepted, it will not be published elsewhere in the same form, in English or in any other language.

\section{Policy and ethics}

The work described in your article must have been carried out in accordance with The Code of Ethics of the World Medical Association (Declaration of Helsinki) for experiments involving humans http://www.wma.net/ en/30publications/10policies/b3/index.html;

EC Directive 86/609/EEC for animal experiments http:/ec.europa.eu/environment/chemicals/lab animals/ legislation en.htm;

Uniform Requirements for manuscripts submitted to Biomedical journals http://www.icmje.org. This must be stated at an appropriate point in the article.

\section{Submission}

Please submit the manuscript electronically (e-mail address: magl@ff.ukim.edu.mk) as a single PDF file, which will be used in the peer-review process. All correspondence, including notification of the Editor's decision and requests for revision, takes place by e-mail removing the need for a paper trail. 


\section{Referees}

Please submit, with the manuscript, the names, addresses and e-mail addresses of 3 potential referees. Note that the editor retains the sole right to decide whether or not the suggested reviewers are used.

Papers received by the Editorial Board are sent to referees. The suggestions/comments of the referees and Editorial Board are sent to the author(s) for further action. The revised article should be returned to the Editorial Board as soon as possible but in not more than 30 days.

\section{Preparation of manuscripts}

\section{Use of wordprocessing software}

It is important that the file be saved in the native format of the wordprocessor used. The text should be typed (1 $11 / 2$ spaced) on A4 paper with margins of $3.0 \mathrm{~cm}$ on each side in single-column format, font Times New Roman, Mac C Times, Macedonian Times and size 11, Keep the layout of the text as simple as possible. Most formatting codes will be removed and replaced on processing the article. In particular, do not use the wordprocessor's options to justify text or to hyphenate words. However, do use bold face, italics, subscripts, superscripts etc. When preparing tables, if you are using a table grid, use only one grid for each individual table and not a grid for each row. If no grid is used, use tabs, not spaces, to align columns. The electronic text should be prepared in a way very similar to that of conventional manuscripts. To avoid unnecessary errors you are strongly advised to use the "spell-check" and "grammarcheck" functions of your wordprocessor.

The pages in the article should be numbered.

Finally, please create PDF file before sending the article. After acceptance, you will be asked to supply the article as wordprocessing document (zip-file).

\section{Appendices}

If there is more than one appendix, they should be identified as A, B, etc. Formulae and equations in appendices should be given separate numbering: Eq. (A.1), Eq. (A.2), etc.; in a subsequent appendix, Eq. (B.1) and so on. Similarly for tables and figures: Table A.1; Fig. A.1, etc.

\section{Abbreviations}

Define abbreviations that are not standard in this field in a footnote to be placed on the first page of the article. Such abbreviations that are unavoidable in the abstract must be defined at their first mention there, as well as in the footnote. Ensure consistency of abbreviations throughout the article.

\section{Units}

Follow internationally accepted rules and conventions: use the international system of units (SI). If other units are mentioned, please give their equivalent in SI.

The names of substances should be in accordance with the IUPAC recommendations and rules or Chemical $A b$ stracts practice.

\section{Math formulae}

Present simple formulae in the line of normal text where possible and use the solidus (/) instead of a horizontal line for small fractional terms, e.g., X/Y. In principle, variables are to be presented in italics.

\section{Footnotes}

Footnotes should be used sparingly. Number them consecutively throughout the article, using superscript Arabic numbers. Many wordprocessors build footnotes into the text, and this feature may be used. Should this not be the case, indicate the position of footnotes in the text and present the footnotes themselves separately at the end of the article. Do not include footnotes in the Reference list.

\section{Table footnotes}

Indicate each footnote in a table with a superscript lowercase letter.

\section{Figures}

Figures (photographs, diagrams and sketches) and structural formulae should each be given on a separate sheet (the place to which they belong in the text should be indicated). The figures should be numbered in Arabic numerals (e.g. Fig. 1). Ensure that each illustration has a caption. Supply all captions separately, not attached to the figure. A caption should comprise a brief title (not on the figure itself) and a description of the illustration. Keep text in the illustrations themselves to a minimum but explain all symbols and abbreviations used.

Please submit the pictures in a black and white version.

Tables

The tables should be numbered in Arabic numerals (e.g. Table 1) and each should be given on a separate sheet (the place to which they belong in the text should be indicated). Number tables consecutively in accordance with their appearance in the text. Place footnotes to tables below the table body and indicate them with superscript lowercase letters. Be sparing in the use of tables and ensure that the data presented in the tables are not duplicated elsewhere in the article. 


\section{Article structure}

Manuscript should contain: title, abstract, key words, introduction, material and methods, results and discussion, conclusion, acknowledgment (if desired) references and summary.

\section{Subdivision}

Divide your article into clearly defined sections (Abstract, Introduction, Material and methods. etc.). Any section or subsection may be given a brief heading. Each heading should appear on its own separate line.

\section{Essential title page information}

Papers should be preceded by a title page comprising: the title, the complete name(s) of the authors, and the author's affiliations.

Title. Concise and informative. Avoid abbreviations and formulae where possible.

Author names and affiliations. Where the family name may be ambiguous (e.g., a double name), please indicate this clearly. Present the authors' affiliation addresses (where the actual work was done) below the names. Indicate all affiliations with a lower-case superscript arabic number immediately after the author's name and in front of the appropriate address. Provide the full postal address of each affiliation, including the country name of each author.

Corresponding author. Clearly indicate (with *) who will handle correspondence at all stages of refereeing and publication, also post-publication. Ensure that telephone and fax numbers (with country and area code) are provided in addition to the e-mail address and the complete postal address.

Each paper must begin with an Abstract which should not exceed more than 250 (original scientific and professional papers) or 100 (short communications) words. The abstract should state briefly the purpose of the research, the principal results and major conclusions. References should be avoided, but if essential, then cite the author(s) and year(s). Also, non-standard or uncommon abbreviations should be avoided, but if essential they must be defined at their first mention in the abstract itself. Immediately after the abstract, provide a list of 3 to 6 keywords arranged in the order according to their importance.

\section{Introduction}

State the objectives of the work and provide an adequate background, avoiding a detailed literature survey or a summary of the results.

\section{Material and methods}

Provide sufficient detail to allow the work to be reproduced. Methods already published should be indicated by a reference: only relevant modifications should be described. Manuscripts which are related to theoretical studies, instead of Material and methods, should contain a sub-heading and the Theoretical background where the necessary details for verifying the results obtained should be stated.

\section{Results}

Results should be clear and concise.

\section{Discussion}

This should explore the significance of the results of the work, not repeat them. A combined Results and Discussion section is often appropriate. Avoid extensive citations and discussion of published literature.

\section{Conclusions}

The main conclusions of the study may be presented in a short Conclusions section, which may stand alone or form a subsection of a Discussion or Results and Discussion section.

\section{Acknowledgements}

Collate acknowledgements in a separate section at the end of the article before the references and do not, therefore, include them on the title page, as a footnote to the title or otherwise. List here those individuals who provided help during the research (e.g., providing language help, writing assistance or proof reading the article, etc.).

\section{References}

\section{Citation in text}

Please ensure that every reference cited in the text is also present in the reference list (and vice versa). Any references cited in the abstract must be given in full. Unpublished results and personal communications are not recommended in the reference list, but may be mentioned in the text. If these references are included in the reference list they should follow the standard reference style of the journal and should include a substitution of the publication date with either "Unpublished results" or "Personal communication". Citation of a reference as "in press" implies that the item has been accepted for publication and a copy of the title page of the relevant article must be submitted.

\section{Web references}

As a minimum, the full URL should be given and the date when the reference was last accessed. Any further information, if known (DOI, author names, dates, reference to a source publication, etc.), should also be given. Web references can be listed separately (e.g., after the reference list) under a different heading if desired, or can be included in the reference list. 


\section{Reference style}

Text: All citations in the text should refer to:

1. Single author: the author's name (without initials, unless there is ambiguity) and the year of publication;

2. Two authors: both authors' names and the year of publication;

3. Three or more authors: first author's name followed by "et al." and the year of publication.

Citations may be made directly (or parenthetically). Groups of references should be listed first alphabetically, then chronologically.

Examples: "as demonstrated (Allan, 1996a, 1996b, 1999; Allan and Jones, 1995). Kramer et al. (2000) have recently shown...."

List: References should be arranged first alphabetically and then further sorted chronologically if necessary. More than one reference from the same author(s) in the same year must be identified by the letters "a", "b", "c", etc., placed after the year of publication.

\section{Examples:}

Reference to a journal publication:

Van der Geer, J., Hanraads, J.A.J., Lupton, R.A., 2000. The art of writing a scientific article. J. Sci. Commun. 163, 51-59.

Reference to a book:

Strunk Jr., W., White, E.B., 1979. The Elements of Style, third ed. Macmillan, New York.

Reference to a chapter in an edited book:

Mettam, G.R., Adams, L.B., 1999. How to prepare an electronic version of your article, in: Jones, B.S., Smith, R.Z. (Eds.), Introduction to the Electronic Age. E-Publishing Inc., New York, pp. 281-304.

Journal abbreviations source

Journal names should be abbreviated according to

Index Medicus journal abbreviations: http://www.nlm. nih.gov/tsd/serials/lji.html

List of serial title word abbreviations: http://www.issn. org/2-22661-LTWA-online.php;

CAS (Chemical Abstracts Service): http://www.cas. org/sent.html.

Manuscripts written in English should contain a Summary in Macedonian at the end of the paper. The summary should contain: title, author(s) full-name(s), surname(s), author's affiliations (institution and address), key words and abstract. Professional papers written in Macedonian should contain a summary in English in which the same data should be included.

\section{Submission checklist}

It is hoped that this list will be useful during the final checking of an article prior to sending it to the journal's
Editor for review. Please consult this Guide for Authors for further details of any item.

Ensure that the following items are present:

One Author designated as corresponding Author:

- E-mail address

- Telephone and fax numbers

- $\quad$ All necessary files have been uploaded

- Keywords

- All figure captions

- All tables (including title, description, footnotes)

- Further considerations: Manuscript has been "spellchecked" and "grammar-checked"

- References are in the correct format for this journal

- All references mentioned in the Reference list are cited in the text, and vice versa

- Permission has been obtained for use of copyrighted material from other sources (including the Web)

\section{After acceptance}

Proofs

One set of page proofs (as PDF files) will be sent by e-mail to the corresponding author. Please list the corrections and return them via e-mail. If, for any reason, this is not possible, then mark the corrections and any other comments on a printout of your proof and return by fax, or scan the pages and e-mail, or by post. Please use this proof only for checking the typesetting, editing, completeness and correctness of the text, tables and figures. Significant changes to the article as accepted for publication will not be accepted.

We will do everything possible to get your article published quickly and accurately. Therefore, it is important to ensure that all of your corrections are sent back to us in one communication: please check carefully before replying, as inclusion of any subsequent corrections cannot be guaranteed. Proofreading is solely your responsibility. Note that Macedonia Pharmaceutical Bulletin may proceed with the publication of your article if no response is received.

\section{Offprints}

The corresponding author, at no cost, will be provided with a PDF file of the article by e-mail. The PDF file is a watermarked version of the published article and includes a cover sheet with the journal cover image.

Additional paper offprints can also be ordered for an extra charge. 